\title{
A Földtani Közlöny története
}

\author{
Természetes, hogy a Földtani Közlöny megindulása, (...) \\ élete, sorvadása vagy felvirágzása összefügg a Társulat sorsá- \\ val. A folyóirat története egyben a Társulat története is, vagy \\ fordítva. (TASNÁDI KUBACSKA András, 1970)
}

\author{
PAPP Gábor
}

Magyar Természettudományi Múzeum, Ásvány- és Kőzettár, 1083 Budapest, Ludovika tér 2. papp.gabor.min@nhmus.hu

\section{History of Földtani Közlöny, Bulletin of the Hungarian Geological Society}

Abstract

Földtani Közlöny (hereafter: the Bulletin), with its 150 volumes, is one of the oldest scientific periodicals in Hungary still in print. Its history has always been a faithful mirror of the changes in the organization and in the financial situation of its publisher, the Hungarian Geological Society (Magyarhoni Földtani Társulat, MFT, hereafter: the Society).

Precedents. The Bulletin replaced Magyarhoni Földtani Társulat Munkálatai [Proceedings of the Hungarian Geological Society]. The five volumes of this first periodical of the Society were published irregularly since 1856 but the last three issues (1867-1870) appeared nearly annually. Vols II-V contained both shorter and longer papers, as well as reports and documents of the life and activities of the Society. In addition to these, the Bulletin, which replaced the Proceedings in 1871, also includes geological news and reviews of geological books and periodicals due to its frequent publication schedule.

Period of founding and finding the profile of the journal (1871-1885). The publication of the Bulletin was made possible by the organizational and financial strengthening of the Society and by the establishment of the Royal Hungarian Geological Institute (Magyar Királyi Földtani Intézet, MKFI, 1869). The Institute took over the task of publishing annals with voluminous papers and annual reports on the geological surveying of the country, whereas the Society published its Bulletin issued in several numbers per year containing shorter articles. The Bulletin was edited by the first and second secretaries of the Society until 1948. Society members received it until 2000 for the membership fee or for a reduced subscription fee. The first 15 years of the Bulletin was a period of frequent changes. In 1878 [Vol. 8] the format changed from small to large octavo. In 1879 [9] the journal became practically bilingual. In order to strengthen its scientific character, in 1880 [10] Földtani Értesító [Geological Reports], a new journal was founded, which published popular articles and took over all the sections of the Bulletin other than original papers. In 1883 [13] Földtani Értesítő discontinued, and not only the "exiled" sections returned to the Bulletin, but the Annual Reports of the Geological Institute were also added. Being too burdensome for the Society, the joint publication lasted until only 1885 [15], but the alliance of the Society and the Institute survived: until 1949 [79], the Bulletin had been the "official journal" of the Geological Institute as well. For a long time, the journal exchanges for the Bulletin were also managed by the library of the Institute.

Years of consolidation (1886-1918). From 1886 to 1918, the Bulletin changed little in character, although József SzABó, president of the Society, wanted to develop it into a reference journal of Hungarian geology, maintaining its role as a publication forum of the members of the Society. Publication costs amounted to 40-60\% of the annual expenses of the Society but publishing has never been a real problem, thanks in large part to state subsidy received annually from 1887 [17] and tripling by 1910 [40]. The systematic recruitment of members from 1908, a controversial matter, and the establishment of two new Sections (Speleological, 1910/13 [40/43] Hydrological, 1912 [42]) contributed to the further increase of the volume of the journal. World War I broke this trend, but by 1918 [48] it was only a decline in the number of pages, as the number of copies reached its peak $(1,200)$ in this year, surpassed only in as late as 1955 .

A period of struggle from the end of World War I till the Communist takeover (1919-1948). After the collapse of 1918 , assets of the Society lost their value and state subsidy became unpredictable. During this period, mining industry companies became important supporters. Publication costs of the Bulletin amounted to $70-80 \%$ of the annual expenses. Therefore, until 1933 [63], generally only one, usually rather slender, issue was published per year, with two, then one year delay. This led to the shortening of articles, and omission or shrinking of sections other than the one containing original papers. In 1931 [61] the bilingualism of the journal changed, articles were published either in Hungarian or in a foreign language (mainly German) with a foreign or Hungarian abstract, respectively. From 1943 [73], a period of long delays in publication and of combined volumes with limited content started again. The first (combined) volume [73/74] was published only in 1947.

Under state control (1949-1989). In 1948 [78], the MFT had to join the state-created Federation of Technical and Scientific Societies (MTESZ). This umbrella organization, providing state control of scientific associations, also took 
over the publication of the Bulletin. Then, after several changes, the Bulletin had been published by the Akadémai Kiadó (Publishing House of the Hungarian Academy of Sciences) from 1954 [84] to 1989 [119]. State subsidy, which came mainly through the MTESZ and through special membership fees paid by state-owned mining companies, provided financial security and stability as compared to the previous period. Editing was done by a permanent editor (from 1967 [97] the president of the Society) helped by an editorial board and by a technical editor (who was also a geologist). It was a great disadvantage, however, that science policy defined the role of the Bulletin as a journal of strictly national reach. Therefore, papers have almost never been published in foreign languages, except for their abstracts. Number of copies peaked at 2,100 in the early 1980s, when the Society itself reached its peak membership (1,680 in 1980). By this time, however, stability increasingly transformed into stagnancy. From 1986, the decline in state subsidy led to an increase in the delay of publications, reaching as much as two years by 1989/1990.

The Society and the Bulletin again on their own feet - the first steps (1990-2000). In 1989, scientific societies were freed from state control but deprived of state support. The era of delays of publication combined with the shrinkage of the volume of the Bulletin once again arrived. However, compared to the years between the two world wars, this period lasted for a shorter time, and ended by the mid-1990s, mainly thanks to the support of MOL Plc. The changeover to computeraided editing, layout and digital printing was done, and since 1995 [125] the quality of paper and print has been excellent. Since 1997 [127], an editor-in-chief oversees and controls the editing process.

From separate subscription fees to free online access — Radical changes in the new millennium (2001-2019). From the turn of the millennium, IT revolution and financial troubles have brought about drastic changes in the access to the Bulletin. Until 2000 [130] Society members received the Bulletin for their membership fee. In 2001 [131], a special subscription fee had to be introduced, which caused the fall of the number of printed copies from about 1250 to 600 . In 2008 [138] the print format was changed from B5 to A4, the cover and the inside were both redesigned. Papers have been available through the web from 2013 [143] for a subscription fee, from 2015 [145] for the membership fee, and from 2017 [147] for free. Since then, papers are supplied with a DOI. Thanks to retrospective digitization, all the volumes of the Bulletin are downloadable from the web for free (including the journals of the Sections of the Society). At the same time, a web-based editing process was introduced. These developments led to the decrease of the number of printed copies to 270 by 2019. The journal is still predominantly Hungarian, although foreign (English) language papers are regularly published.

Keywords: cultural history, journal history, Földtani Közlöny (Bulletin of the Hungarian Geological Society), Magyarhoni Földtani Társulat (Hungarian Geological Society), science history

Összefoglalás

A tanulmány Magyarország egyik legrégebbi tudományos folyóirata történetének áttekintésével a Magyarhoni Földtani Társulat (MFT) történetének egyfajta vetületét is adja.

A Földtani Közlöny az MFT időszakosan megjelenő, hosszabb-rövidebb tanulmányokat, a társulati élethez kötődő írásokat és dokumentumokat egyaránt tartalmazó Munkálatait váltotta fel. A Közlönyben — évi többszöri megjelenése miatt — szakmai hírek és irodalmi ismertetések is helyet kaphattak.

A Közlöny 1871-es elindítását az MFT szervezeti és anyagi megerôsödése és a földtani kutatás intézményesülése (Magyar Királyi Földtani Intézet [MKFI], 1869) tette lehetôvé. Az első tizenöt év az útkeresés jegyében telt. A folyóirat 1879-től [9. évf.] gyakorlatilag kétnyelvú (magyar és német) volt. 1880-1882 közt [10-12] kizárólag eredeti értekezéseket közölt, mert az összes többi rovatát átvette a — népszerú cikkeket is tartalmazó — Földtani Értesítő. 1883-tól [13] e rovatok visszakerültek a Közlönybe, sốt 1885-ig [15] az MKFI Évi Jelentései is itt jelentek meg. A lap ezután is (1949-ig [79]) viselte a Földtani Intézet hivatalos közlönye megjelölést.

Az 1886-1918 közti konszolidált évek során a lap jellege keveset változott. Megjelenéséhez biztos hátteret adott a rendszeres és növekvő állami támogatás. A tagtoborzás és az új szakosztályok alakulása a tagdíjbevételt, a terjedelmet és a példányszámot is tovább növelte, de az I. világháború megtörte ezt a fejlődést.

Az I. világháborús összeomlás után a társulat vagyona elértéktelenedett, és az állami támogatás is esetlegessé vált. E küzdelmes időszakban egészen 1933-ig [63] általában csak évi egy füzet jelent meg — az is több-kevesebb késéssel. A cikkek megrövidültek, az eredeti értekezéseken kívüli rovatok kimaradtak vagy összezsugorodtak. 1931-től [61] a cikkeket vagy magyarul, vagy németül közölték, ellentétes nyelvú kivonattal. 1943-tól [73] újból a csúszások és a drasztikus terjedelemcsökkenés időszaka jött el. A fordulat évével (1948 [78]) bezárólag ismét legfeljebb csak évi egy füzet jelent meg.

1948-ban [78] az MFT-t betagolták a Músszaki és Természettudományi Egyesületek Szövetségébe (MTESZ). Az „államosított” Közlönyt — több változás után — a 84.-től a 119. évfolyamig az Akadémiai Kiadó adta ki. A lapot az MFT titkárai helyett egy állandó szerkesztő (1967-től [97] a Társulat elnöke) által vezetett bizottság szerkesztette. A Közlönyre a hazai hatáskörú földtani szaklap szerepét osztották, ezért idegen nyelvú cikk alig jelent meg benne. Az állami támogatás nyújtotta stabilitást 1986-tól [116], a dotáció leépülése nyomán, újra a csúszások és technikai fogyatékosságok kora váltotta föl.

1990-től [120] az állami kontrollal együtt az állami szubvenció is megszúnt, de a csúszások és a terjedelmi korlátok periódusa — főként a MOL Nyrt. támogatásának köszönhetóen — az 1990-es évek közepére elmúlt. Lezajlott a számítógépes átállás, megjavult a papír és a nyomtatás minősége, 1997-ben [127] a fôszerkesztői poszt bevezetésével megújult a szerkesztés menete is.

Az új ezredévben az informatikai forradalom és a pénzügyi gondok drasztikus változásokat hoztak. 2001-ben [131] be kellett vezetni a külön előfizetési díjat. 2008-ban [138] a Közlöny A4-es méretû lett. A cikkek 2013-tól [143] előfizetés, 2015-tôl [145] tagdíj ellenében, 2017-től [147] viszont már ingyenesen hozzáférhetők a világhálón, sôt a retrospektív digitalizálásnak köszönhetően ugyanez a korábbi számokra is elmondható. A digitálisan szerkesztett lap továbbra is — de már nem kizárólagosan — magyar nyelvú maradt.

A történeti rész után egy tematikus áttekintést nyújtó Adattár zárja a tanulmányt.

Tárgyszavak: folyóirat-történet, Földtani Közlöny, kultúrtörténet, Magyarhoni Földtani Társulat, tudománytörténet 


\section{Bevezetés}

A Földtani Közlöny 150. évfolyamának megjelenése alkalmából íródott jelen áttekintés előzménye a Közlöny honlapján online elérhetô összefoglaló volt, melynek megírását BAKSA Csaba, a Magyarhoni Földtani Társulat néhai elnöke kezdeményezte. Ahhoz hasonlóan e cikk sem tudománytörténeti, hanem kiadványtörténeti célzatú, tehát nem a Közlöny tudományos tartalmának változását tekinti át, hanem a Közlönynek, mint e tartalom hordozójának történetét (1. ábra). A kronológiai sorrendet követő fő rész után egy függelékként közölt tematikus adattár ad további hasznos információkat listák, illetve a hozzájuk kapcsolódó vagy önálló szöveges részek formájában. Az áttekintés forrásául az irodalomjegyzékben felsorolt, a Közlönyben szokásos módon hivatkozott önálló publikációk, illetve maga a Közlöny szolgált, elsősorban a közgyưlések elnöki megnyitói és (fő)titkári jelentései, az 1918 előtti időszakra nézve ezeken felül még a választmányi ülések kivonatos jegyzókönyvei. Ezekre szögletes zárójelben megadott kötetszámmal és a kettőspont után következő oldalszámmal hivatkozom (pl.: [7: 37], a kötetszám előtt M. a Munkálatokat, FÉ. a Földtani Értesítőt, R. a repertóriumokat jelzi. Az oldalszámot hasonlóképpen megadtam a hivatkozott könyvek esetében is. Igen fontos forrást jelentettek a Társulat több, a köszönetnyilvánításban név szerint felsorolt tisztségviselőjének közlései is.

\section{Elözmények}

A Magyarhoni Földtani Társulat múködésének első két évtizedében több okból sem vállalkozhatott rendszeres folyóirat kiadására. Egyik oldalról ennek hiányoztak az anyagi feltételei. A Bach-korszak, majd a Schmerling-provizórium alatt a Társulat nem számíthatott állami támogatásra, és önerőre sem igen támaszkodhatott, mert a rendes tagok száma a kiegyezés előtt nem érte el a kétszázat sem, és ők 1862-ben már összesen 735 évi tagdíjjal voltak adósak [M.II: 207]. Állami földtani intézményrendszer híján a potenciális cikkírók száma is viszonylag kicsi volt. Így a kiadványok megjelentetésében a korra és a frissen alakult társulatokra is jellemző egyszeri nekibuzdulások és hosszú szünetek váltakoztak egészen a kiegyezésig, amikorra megteremtődtek egy évkönyvszerű kiadvány megjelentetésének anyagi feltételei.
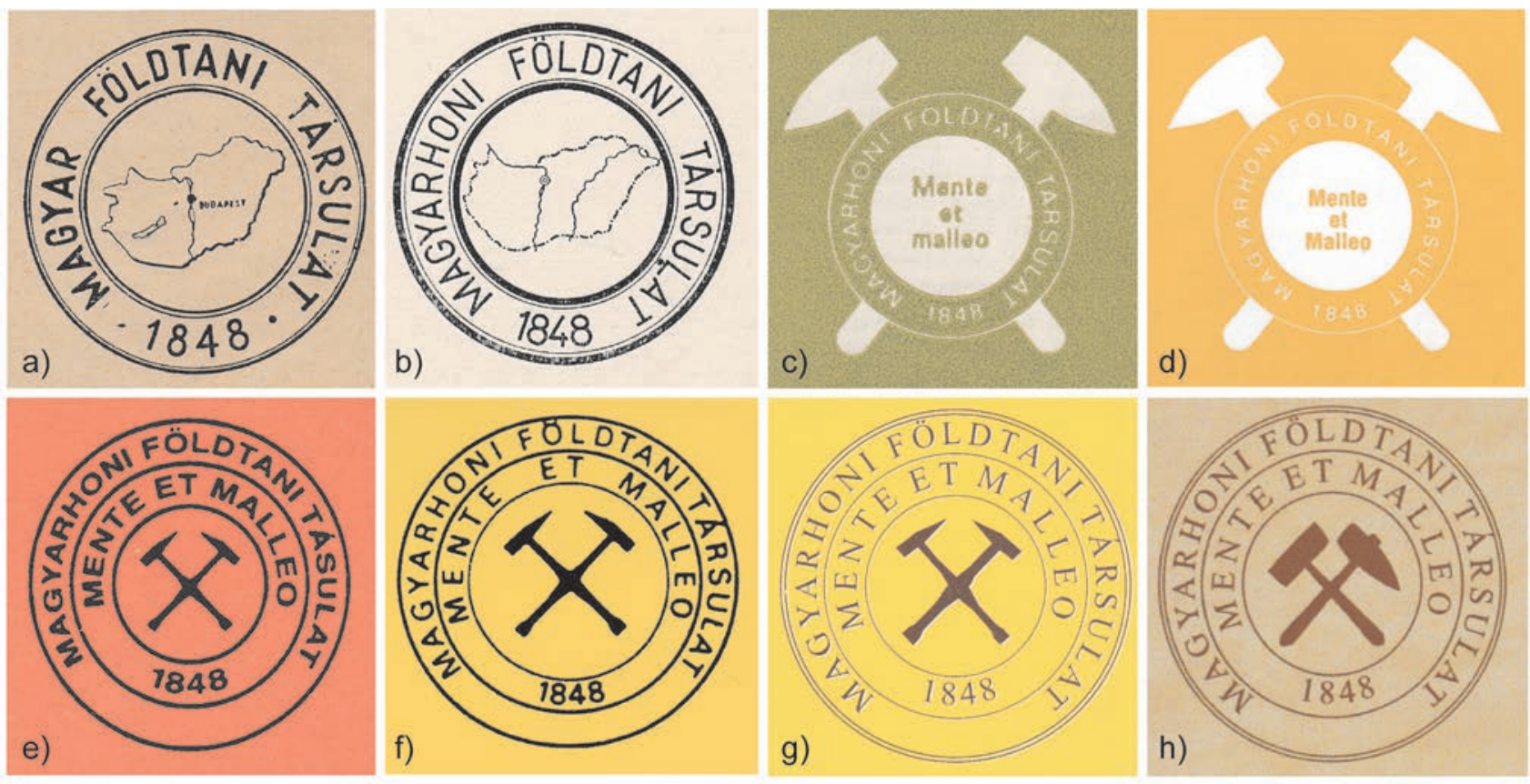

1. ábra. Változó szimbólumok. A Társulat (és a Közlöny) történetének lenyomatai a lap címlapján lévő társulati emblémán

(a) 1952 [72] - 1965 [85]: Az 1950-es közgyủlési határozat nyomán a Magyarhoniból eltűnt a „honi”. Az emblémába belerajzolták a határokat, melyeket nem lehetett fizikailag és nem illett szakmailag átlépni, alul pedig a „legendás” alapítási évszám áll. (b) 1966 [86] - 1969 [89]: Az 1962-ben visszaállított névalak csak négy év késéssel került a címlapra. (c): 1970 [100] - 1991 [121]: Kezd színesedni a világ (bár csak egyszínủ), és a hagyományos formájú geológuskalapácsokkal kiegészített embléma közepén az országhatárok helyett már a nemzetközi geológus-jelmondat található. (d): Ugyanaz, a borító lassú „elsárgulását” tükrözve. (e) 1992/1 [122/1]: A visszanyert önállóság kezdeti nehézségei: Megújult embléma a hírhedt piros számok egyikéről, modernizált geológuskalapácsokkal. (f) 1992/2-4 [122/2-4] - 2000 [130]: Ugyanez, kis tipográfiai korrekcióval. (g) 2001 [131] - 2007 [137]: Sokkal szebb kivitel, egy - a 2001-ben befizetett külön előfizetési díj miatt - sokkal drágább lapról. (h): 2008 [138] - : Modernizálódás és tradíció: színes nyomású embléma a többszínnyomású címlapról a geológuskalapácsok helyett bányászkalapáccsal és -ékkel

Figure 1. Changing symbols. Impressions of the history of the Society (and the Bulletin) on the emblem of the Society printed on the front cover of the journal (a) 1952 [72] - 1965 [85]: The new name of the society, introduced in 1950, can be read in the legend. The emblem also shows the frontier of the county, which was impossible to cross physically and inadvisable to cross scientifically in those days. The "legendary" year of foundation of the Society stands below. (b) 1966 [86] - 1969 [89]: The traditional name was restored in 1962 but the emblem was replaced only four years later on the cover of the Bulletin. (c): 1970 [100] - 1991 [121]: There are again colours in the world (though only one), and instead of national borders, the international motto of geology is in the middle of the emblem, which also features the crossed geologists' hammers (of the traditional design). (d): The same in the yellowish colour of the later covers. (e) 1992/1 [122/1]: Teething troubles of recovered independence: The first version of the new emblem with geologists' hammers of the present-day design from the issues with the notoriously miscoloured cover. (f) 1992/2-4 [122/2-4] - 2000 [130]: The same with a slight typographic correction. (g) 2001 [131] - 2007 [137]: A design, which was much more attractive on the cover of the Bulletin, which was much more expensive (due to the special subscription fee introduced in 2001). (h): 2008 [138] -: Modernization and tradition: A redesigned emblem printed in colour from the multicolour cover of the Bulletin. Miners' hammer and axe replaced geologists' hammers 
A Magyarhoni Földtani Társulat (MFT) első saját kiadványa a szúk két évnyi tényleges múködés után 1852-ben megjelent „Első jelentés a Magyarhoni Földtani Társulatról” volt. A németül is kiadott füzetkét, mellyel a fiatal társulat hírt adott létezéséről, KováTs Gyula titkár szerkesztette. Egy történeti áttekintés és a múködési jelentés mellett az alapszabályokat, a tagok és tisztviselők névsorát, a pénztári jelentést és a Társulatnak küldött ajándékok listáját tartalmazta, valamint utolsó lapján az ígéretet, hogy „egy második jelentés, melly a szakgyülésekben tartott tudományos értekezéseket, legalább kivonatképpen tartalmazandja, még ez év folytán sajtó alá kerülend" [M.I: 35]. E második jelentés azonban nem jelent meg. Az 1855. III. 22-i választmányi ülés elhatározta, hogy a Társulat magyar és német nyelvú évkönyveket fog kiadni (VENDL 1958: 55). Évkönyv helyett azonban a Magyarhoni Földtani Társulat Munkálatai elsô kötetének kizárólag tudományos értekezéseket tartalmazó elsô füzete jelent meg 1856-ban. KovÁTs Gyula szerkesztôi előszava szerint ,ezen füzettel kezdi meg a magyarhoni földtani társulat tudományos munkálatainak kiadását, mellyek vagy tagjaitól származnak, vagy megbízásából készuiltek. (...) Fényes kiadásokat csak az állam által pénzzel segített testületek eszközölhetnek, s még ezen kiadás is lehetetlenné vált volna, ha ezt magas pártfogójának herczeg Eszterházy Pál Ố nagyméltóságának fényes bőkezúsége lehetővé nem teszi [M.I: [5]].” A füzet németül is megjelent, már csak azért is, mert kiadását a német orvosok és természetvizsgálók Bécsben rendezett összejövetelére időzítették [M.II: [4]]. A kötet csonkán maradt, noha a Munkálatok kiadása az 1856-ban elfogadott társulati alapszabály 5. §-ában a társulat múködésének jelentékenyebb eszközei közt a 3. helyen szerepel [M.III: 198]. Továbbra sem jelent meg a társulat múködéséről beszámoló, ,,rövid időn kiadandó" második jelentés sem. SCHMIDT (1880) visszatekintése szerint „a kiadványok szerfölött késedelmes közzététele” volt az, ami a társulat iránti ,érdeklődést folyton apasztá, úgy hogy csakis a geologok és bányászok szokott szívósságának köszönhetô, hogy a társulat ügye az enyészet homályába nem költözött".

Hét év szünet után, melyet VendL (1958: 64) az anyagi fedezet hiányával magyarázott, SzABó József szerkesztésében végre 1863-ban megjelent az MFT Munkálatainak II. kötete. Ezúttal az alkalmat az orvosok és természetvizsgálók pesti vándorgyúlése szolgáltatta, mely hosszas szünet után követte azt az 1847-es soproni gyúlést, ahol az MFT megalapítására vonatkozó indítvány elhangzott [M.II: [4]]. A kötet 17 szakcikk mellett tartalmazta a társulat múködési adatait is (ülések, alapszabályok, tagok és tisztségviselők, pénztári jelentés, könyvtári jelentés). Újabb négy év kihagyás után jelent meg HANTKEN Miksa szerkesztésében a hasonló felépítésú III. kötet, mely HANTKEN előszava szerint „a társulat viszonyai jobbra fordultának közvetlen eredménye" volt [M.III: [17]]. Ez az 1866. IV. 25-i választmányi ülés határozata nyomán már csak azokat az előadásokat tartalmazta a szaküléseken tárgyaltak közül, melyeket a választmány erre érdemesnek tartott (VENDL 1958: 69). Korábban az 1866. III. 14-i közgyúlés arról határozott, „hogy a beadott szakértekezések a társulat közlönyébe, mint forrásmunkába azon nyelvben vétessenek fel a melyben beadatnak" [M.III: 179]. A Munkálatok ezután, HANTKEN Miksa titkársága alatt már csaknem évi rendszerességgel jelentek meg (IV. kötet: 1868, V. kötet: 1870), jelezve egy szabályszerú szakfolyóirat indításának igényét és lehetőségét is. 1867-től már az évente beérkező 900 osztrák értékű forint (a továbbiakban: frt) körüli tagdíj már fedezte a kiadás költségeit, hiszen például 1869-re — amikor végül is nem jelent meg — 900 frt volt a Munkálatok költségelőirányzata [M.V: 216].

\section{A megalapítás, majd az útkeresés periódusa (1871-1885)}

1869-ben megalapították a Magyar Királyi Földtani Intézetet (MKFI), és az állami támogatással folyó rendszeres földtani kutatás beindításával ,ezen nevezetes momentum levette a társulat bilincseit" (SCHMIDT 1880). Egy évre rá az MFT 1870. november 9-i közgyúlése új alapszabályt fogadott el, és döntött arról, hogy ,,az eddig megjelenő évkönyv helyett havi füzetekben megjelenő közlöny (2. ábra, A) szerkesztessék" [1:88]. Az első másfél évtized alatt a folyóirat több koncepcionális változáson esett át, de 1886-ra kiforrott az azóta is kisebb módosulásokkal fennálló jelleg és szerkezet. A kiadás maga nem okozott megoldhatatlan problémákat a Társulatnak, bár a beérkező, átlagban 11001200-ról 1700-1800 frt-ra növô évi tagdíjbefizetések a periódus végén már alig fedezték a Közlönynek 6-700frt-ról 2000 frt közelébe emelkedő nyomdaköltségét, amely a Társulat évi kiadásainak általában 40-60\%-át tette ki.

Az új társulati alapszabály 3. §-ában a társulat múködésének jelentékenyebb eszközei közt a szakgyưlések tartása után már a 2. helyen szerepel a „Földtani Közlöny kiadása” [1: 49]. A szerkesztő az alapszabály 17-18.§. alapján a társulat első titkára volt, munkájában a másodtitkár segítette vagy helyettesítette [1: 51]. Az 1871 tavaszán megjelent első szám (2. ábra, B) szerkesztői előszava [1: 1-2] rámutatott arra, hogy a folyóirat e formában történő megszületéséhez is hozzájárult az MKFI alapítása. A Társulat ugyanis ezzel mentesült az alól, hogy az ország földtani viszonyainak kutatására vonatkozó terjedelmes közleményeket kelljen közreadnia, ezek ugyanis megtalálják a helyüket az Intézet kiadványaiban. A Társulat vezetése úgy döntött, hogy „,egy önálló földtani évkönyv további kiadását nem tartja szükségesnek”, és azt a célt túzte ki maga elé, hogy „havi füzetekben rövid kivonatokban és cikkekben közölni fogja az irodalom s általában a tudomány terén történt haladást és felfedezéseket, figyelemmel kíséri a hazai tudományos intézetek múködéseit, szakgyúléseket rendez, s az ezekben előadott tárgyakat a tagok tudomására hozandja. Ezen havi füzetek által a társulat kettős célt remél elérni; egyrészt erejéhez képest igyekezni fog a földtani tudományok iránt szélesebb körökben is kedvet és érdekeltséget gerjeszteni, másrészt a külső tagokkal is folytonos összeköttetésben lévén, inkább lesz alkalma azok nézeteit és kívánalmait megismer- 


\section{FÖLDTAÑI KÖZLLONY}

KIADJA

A MAGYARHONI FÖLDTANI TÁRSULAT.

A VÁLASZTMÁNY MEGBIZÁSÁBÓL SZERKESZTETTÉK

winkler Benö,

TÁRSULATI ELsó TIT TAR (april hó végeig)

aztán

Bernath Jozsef es Koch Antal TAKSULATI TITKAKOK.

ELSO EVTOLYAM

I-X. szam.

2 kônyomatú táblàval ès a szövegbe nyomott । famstszvèsanycl.

ชริ

PEST, 1872.

NYOMATOTT KHÓR ES WEIN KÖNYVNYOMDÁJÁBAN

a)

1871. I., II., III. SZ.

FÖLDTANI KÖZLÖNY A MAGYARHONI PÖLDTANI TÁRSULAT.

A VÁLASZTMÁNY MEGBIZÁSÁBOL SZERKESZTI

$$
\text { WI N K L ER } \beta \text { E N ó, }
$$

b)

Január, Fobruár és Mározius havi füzet.

2. ábra. a) A Földtani Közlöny első évfolyamának címlapja. PAPP Károly (1940-1941 közt elnök) példánya, rajta GüLL Vilmos (1907-1909 közt másodtitkár) bélyegzőnyomatával. b) A legelső szám első oldalának címfeje

Figure 2. a) Front cover of the Bulletin from the copy of Karoly PAPP (president between 1940-1941), bearing also the stamp mark of Vilmos GüLL (second secretary between 1907-1909). b) Headline from the first page of the very first issue

ni s azokat lehetőleg teljesíteni.” E célkitúzéseknek a Földtani Közlöny — a lényegében azóta is csak a belsố arányokban változó - hármas tartalmi tagozódással tett eleget, közölve (1) értekezéseket, vagyis eredeti cikkeket, (2) leginkább magyar vonatkozású irodalmi ismertetéseket és (3) vegyes közleményeket, köztük a társulati életre vonatkozó beszámolókat.

A Közlöny elsősorban a szaküléseken elhangzott elő- adások anyagát tartalmazta, de a társulati bemutatás hiánya nem volt kizáró ok [1. pl. 7: 37, 9: 52]. Amint VENDL (1958: 80) írja, ,,az 1871. évtől kezdve tehát a Földtani Közlöny volt a Társulat tudományos munkásságának tükre és lényeges eszköze". VENDL az 1950-ig terjedő időtartamra nézve megállapította, hogy a Közlöny köteteiben jelentek meg ,,a legfontosabb eredeti kutatásokon alapuló földtani értekezések; a nagyobb monográfia jellegú munkák és az állami felvételek eredményei kivételével. Noha a M. Kir. Földtani Intézetnek külön kiadványai voltak, az intézet geológusai mégis szívesen közöltek a Közlönyben rövidebb értekezéseket. Ez a folyóirat ugyanis (...) mozgékonyabb volt, hamarabb jelent meg (...), mint a Földtani Intézet nagyobb kiadványai”. Az említett MKFI kiadványok közül az Évi Jelentés (1876-tól) az Intézet földtani felvételeit és múködési adait, az Évkönyv (1871-től) a munkatársak önálló közleményeit adta közre. A korabeli — nagyjából a Közlönnyel egyidős — a tág értelemben vett geológia területével is foglalkozó, bizonyos „,konkurenciát” jelentő egyesületi szaklapok közül a Bányászati és Kohászati Lapok (1868-tól) tematikailag csak kevéssé érintkezett a Közlönnyel; a Természettudományi Közlöny (1869-től) általában nem közölt eredeti tanulmányokat. Az Erdélyi Múzeum-Egylet Orvos-Természettudományi Szakosztálya 1876-tól adott ki változó címú folyóiratot. Az akadémiai kiadványok közül az Értekezések a természettudományok köréból (1869-től) az MTA ülésein elhangzott előadásokat adta közre. A Mathematikai és Természettudományi Közlemények (1861-től) fóleg Magyarországra vonatkozó, többnyire hosszabb lélegzetú dolgozatokat tartalmazott. A Mathematikai és Természettudományi Értesító (1882-tôl) az előbbinek rendszeresebben megjelenő és rövidebb közleményeket is megjelentető kiegészítője volt. A Mathematische und Naturwissenschaftliche Berichte aus Ungarn (1882-től) különböző hazai természettudományos folyóiratok (köztük a Földtani Közlöny) hasábjain megjelent cikkek német változatát tartalmazta. Az MNM természetrajzi osztályainak kétnyelvú folyóirata, a Természetrajzi Füzetek (1877-től) a múzeum munkatársainak ásványtani, kristálytani és paleontológiai írásait (is) közölte.

A Földtani Közlönyt a társulati tagok a tagdíj fejében, tagi járandóságként kapták. A társulat a földmúvelési, ipari és kereskedelmi minisztériumtól kérvényezte a lap ingyenes postai szállítását, ami ugyan nem volt lehetséges, de az MFT is megkapta a Természettudományi Társulat által élvezett kedvezményt, mely szerint ,a társulat közlönyét havi füzetekben minden 2 1/2 lat [43,5 g] után egy újságjeggyel (1kr. díj mellett) küldheti szét" [1: 91]. A Földtani Közlöny kötetei tehát hivatalosan havi füzetekból álltak, de az elvileg 10, majd 1873-tól [3. évf.] 12 füzet valójában mindig összevonva jelent meg, eleinte évi 7-8, majd 4-5 alkalommal. A cikkeket kísérő vonalas ábrák száma az elsô években tíz körül mozgott. A nagyobb terjedelmú térképek, szelvények, illetve az árnyalatos illusztrációk (litográfiák, 3. ábra) és szintén litografált kristályrajzok külön táblákra kerültek, ezek száma általában kötetenként tíz alatt volt. A lap formátuma 1877-ig [7] a mai A5 mérethez hasonló kis, majd az 1878. I. 20-i választmányi 


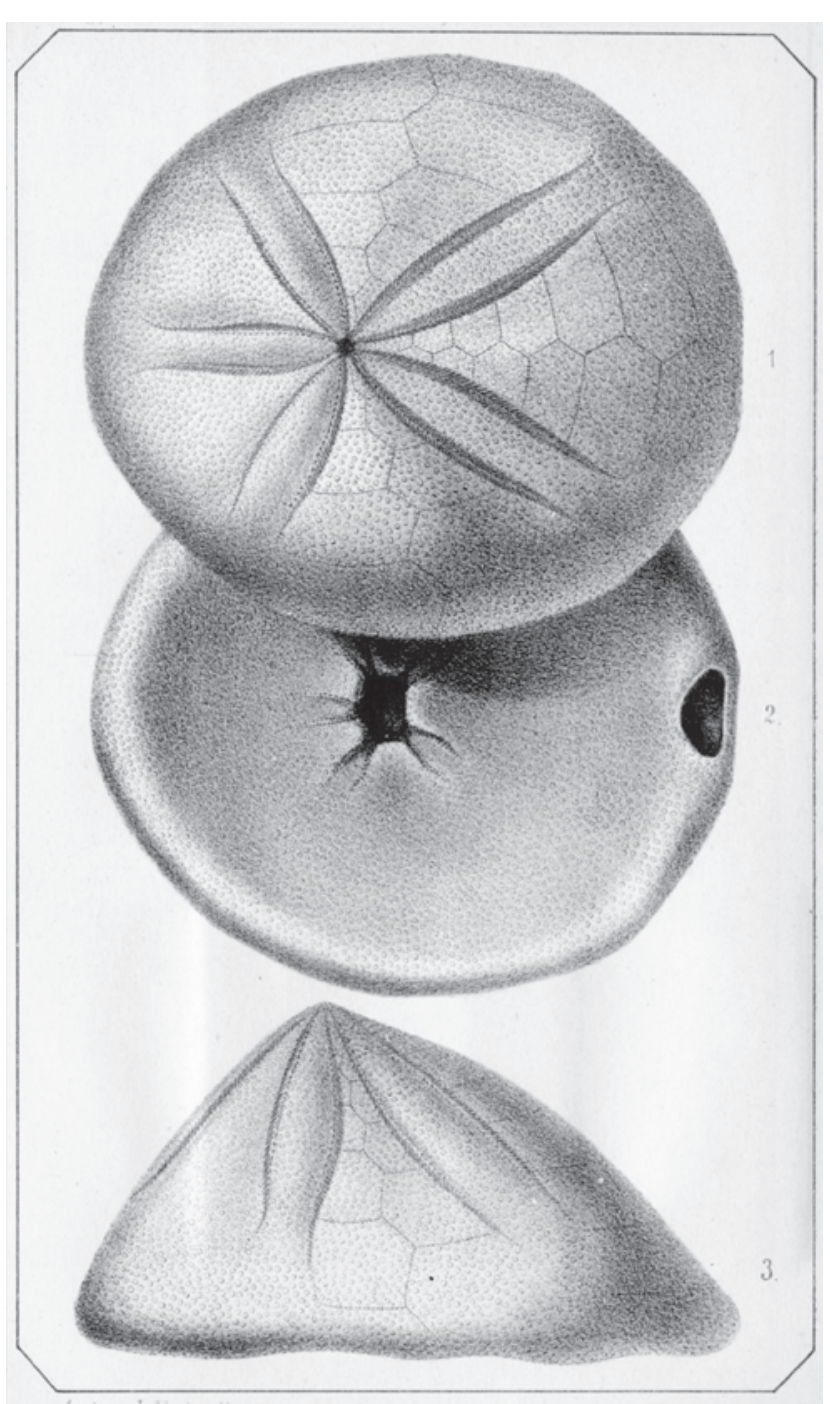

3. ábra. Kőnyomatos illusztráció a Földtani Közlöny 3. évfolyamából (Echinolampas conoideus, PÁVAY Elek rajza)

Figure 3. Lithography illustration from Vol. 3 of the Bulletin (Echinolampas conoideus, drawing by Elek PÁVAY)

ülés határozata nyomán [9: 54] a B5 mérethez közeli nagy oktáv volt. Eleinte Khór és Wein nyomdájában készült, majd 1874-től [4] — vélhetőleg annak nyomán, hogy az 1873. XI. 20-i választmányi ülés szebb kiállításban és jobb papiroson történő megjelentetést határozott el [4: 23] — a Légrády testvérek nyomdájában. A 4. évfolyam mellékleteként jelent meg PoŠEPNÝ ,bányageolog úrnak nagyobb terjedelmú, gyönyörű táblázatokkal ellátott, Rézbánya vidékére vonatkozó nagybecsú múve" [4: 29, l. az Adattárat is].

Már kezdetben igyekeztek a Földtani Közlöny túlnyomórészt magyar nyelvú tartalmát külföldön is megismertetni úgy, hogy a cikkek német kivonatát megküldték a bécsi cs. k. földtani intézet igazgatójának a Verhandlungen der $k$. k. geol. Reichsanstalt füzeteiben történő megjelentetés céljából [8: 34, 9: 54]. Sajátos megoldás volt, amikor 1873-ban [3] PÁvAY cikkét egy (a 3. ábrán bemutatott) új Echinolampas-fajról kéthasábos tördelésben, hasábonként magyarul, illetve németül közölték, vagy 1877-ben [7] HERBICH „Geo-

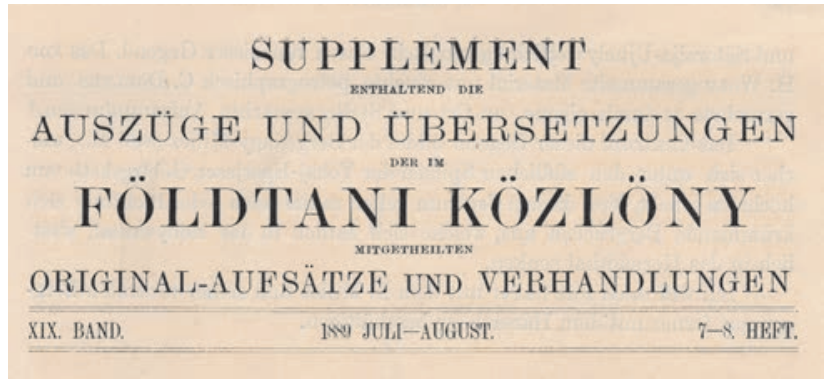

4. ábra. A Földtani Közlöny német nyelvű szupplementumának címfeje [19/7-8] Figure 4. Headline of the German supplement of the Bulletin [19/7-8]

lógiai tapasztalatok az erdélyi érchegység keleti szélén" címú tanulmányának magyar és német szövegét a szembenézó oldalpárokon helyezték el. 1879 e téren fontos változást hozott. A március 5-i rendkívüli közgyúlés elfogadta a választmány előterjesztését arra vonatkozóan, hogy ,a Földtani Közlöny eredeti értekezései a folyó évtől kezdve a magyar szövegen kívül még német, francia vagy angol nyelven is közzététessenek” [9: 64, 9: 136], ,,melyet a tudomány nemzetközi összefüggése követelt" [FÉ.1: 19]. Ettől kezdve, amint a kétnyelvú címlap is tükrözte, a cikkeket, sốt a társulati élet híreit is hol a magyar cikkekkel egy füzetben, hol szupplementum gyanánt (4. ábra) idegen nyelven közzétették. Noha francia és angol nyelvú közlések is lehetségesek voltak, túlnyomórészt a cikkek német fordítása jelent meg. Mindennek üdvös hatása volt a Társulat csereviszonyaira, hiszen a — fôként külföldi — cserepartnerek száma a kétnyelvúsítés előtti 25-30-rôl a MKFI-n keresztül elbonyolított cseréket beleszámítva 1892-re 160, 1902-re 170, 1912re 200 fölé nőtt (1. az Adattárat is).

Már a következő évben a 10. évfolyammal újabb nagy horderejű átalakulás történt. Az 1880. I. 18-i választmányi ülés elhatározta, hogy a kéthavonta megjelenő Földtani Közlöny csak eredeti értekezéseket fog tartalmazni, beleértve a korábbi „Vegyesek” rovatból kivett Rövid közleményeket, míg az Irodalom, a (tényleges) Vegyesek és a Társulati ügyek rovatok, népszerúsítő cikkekkel megtoldva, a Földtani Értesítő címmel évi nyolc füzetben, minden szakülést követő vasárnap megjelenő melléklapba kerülnek át. Az új orgánum céljai a következők voltak: 1. Meghatározott időben és gyorsabban jelenvén meg, a Társulat tagjai közt rendszeres és élénk összeköttetést tart fenn. 2. A földtani ismeretek részére nagyobb és általánosabb érdeklődés felkeltésére törekedve beszámol a Társulat múködésérôl, s nyilvántartja a hazai és a hazánkra vonatkozó irodalmat. Emellett ismeretterjesztő cikkeket közöl a múvelt magyar közönség számára ([FÉ.1: 28-29] és VENDL 1958: 100). A reményteljesen induló folyóirat 3. kötetének utolsó öt füzete helyett azonban már csak két összevont szám jelent meg, ami előre jelezte, hogy a rövid életú ,,profiltisztítás” a melléklappal együtt az 1882-es évvel [a Közlöny 12. kötetével] bezárólag véget ér. Ennek okaként a választmány azt jelölte meg, hogy a kicsiny számú közremúködő hat olyan társulat és folyóirat között oszlik meg, ahol földtani és rokon tárgyú írásokat közölnek ([13: 69] és VENDL 1958: 102). 
A 13. kötet első lapján „Olvasóinkhoz” címmel megjelent közlemény így újabb változást harangozhatott be. Elsô mondata szerint „,a Földtani Közlönynek 1883 január hónapjától kezdve új folyama indul” [13: 1]. A Földtani Értesítố megszúntével ugyanis nem egyszerúen a korábbi helyzet állt vissza, hanem a Társulat és az MKFI az 1883. I. 24-i közgyúlés döntése, illetve az Intézetet felügyelő miniszter egyetértése nyomán szövetségre lépett egymással, így a Közlöny címlapjára felkerült az ,egyszersmind a m. kir. Földtani Intézet hivatalos közlönye" felirat is. A lépéshez az MKFI-nek az a terve vezetett, mely szerint a korábban nem hivatalosan a Közlönyben megjelentetett felvételi jelentéseket saját maga adta volna ki. A megállapodás szerint ezek és az Intézet egyéb tudósításai végül továbbra is a Földtani Közlönyben jelentek meg immáron hivatalos formában, ennek fejében a Társulat 1883-ban 300 frt segélyt kapott. A Társulat az Intézet cserepéldányosai számára a Földtani Közlönyből mintegy 100-200 példányt engedett át, és felajánlotta, hogy a terjedelmesebb eredeti értekezéseket az Intézet Évkönyvének adja át közlésre [13: 69].

E koalíció nem volt előzmény nélküli, hiszen az MFT és az MKFI között a Társulat alapszabályában rögzített — és az állam által elismert, sốt anyagilag is támogatott — szoros kapcsolat volt. Az illetékes miniszter az MFT-nek 1871-től 200 [2: 62], 1873-tól 300 [4: 22,], 1876-tól 400 példány [7: 24] erejéig ingyenesen, azon felül önköltségi áron engedélyezte az intézeti évkönyv átvételét tagjai részére. A Társulat viszont az 1876. I. 24-i közgyúlés határozata nyomán a társulati könyvtárat átadta az MKFI-nek [7: 24]. Az MFTMKFI koalíció megkötésekor egy szerkesztőbizottság is alakult (1. bóvebben az Adattárban), az „Irodalom” rovat megtöltését pedig egy tizenkét tagú referáló bizottságra bízták [13: 2]. Elhatározták, hogy „,a Közlöny ezentúl ismét rövidebb időközökben fog kiadatni, lehetőleg úgy, hogy a nyári szúntek [sic!] kivételével minden egy-két hónapra essék egy füzet" [13: 1], de ezt ezúttal sem sikerült megvalósítani. Ugyanekkor nyomdát is váltottak, a Közlöny 1883-tól [13] egészen 1920-ig [50] a Franklin Társulat nyomdájában készült. Említésre méltó még, hogy 1883-tól a tartalomjegyzék mellett (és azzal együtt elkülönítve római számmal lapszámozott) 20-30 oldalas, részletes betûrendes tartalommutató (tárgyszavas index) is volt. Korábban csak a legelsô évfolyam tartalmazott ilyet, viszont az 1884-ben HALAVÁTS Gyula szerkesztésében megjelent — és 1882-ig az MFT összes addigi kiadványát felölelő — tartalommutató ([R1] az Adattárban) retrospektíve pótolta e hiányosságot.

$\mathrm{Az}$ „Irodalom” rovat tervezett megerósítése nem sikerült olyan mértékben, mint amennyire az elnök, SzABó József kívánta volna, aki a Közlönyt a tagok munkálatainak közlésére szolgáló fórumon túlmenően - mai kifejezéssel élve - a magyar geológia referáló folyóirataként képzelte el: „társulatunk Közlönyének mindez ideig egy lényeges hiánya van. Füzeteinek homlokára oda vannak nyomtatva a sokat ígérô szavak, hogy havi folyóirat «Magyarország földtani, ásványtani és őslénytani megismertetésére s a földtani ismeretek terjesztésére.» (...) a magyarhoni földtani társulat Közlönye nem egészen az, a minek lennie kellene, nem egészen hú tükre annak, a mi Magyarországon a geológia és társtudományai terén történik. S ezt az érzékeny hiányt nem egyéb, mint irodalmi rovatának hézagos és tökéletlen volta okozza!" [15: 164]. Ez a Szabó által máskor is hangoztatott óhaj [16: 58] később sem válhatott valóra, e téren a legtöbb, amit a Közlöny adni tudhatott, a magyar szerző́k geológiai tárgyú közleményeinek éves repertóriuma volt, mely 1900 és 2000 között jelent meg (JÁMBOR 2006).

A Közlöny ezen „új folyama” is csak három évig tartott. Ahogy az 1885-ös titkári előterjesztés fogalmaz: ,a Közlöny terjedelme az idén ismét fenyegetôen kezd növekedni" [15: 359]. Ekkor a lap a tervezett 26-30 helyett már 37 nyomtatott íves volt, ebből 18 ívet foglaltak el az intézeti jelentések. Emiatt évról évre növekedett a következő évre átcsúszó cikkek száma. Ezenfelül a minisztérium által az MKFI-n keresztül fizetett 300, majd 1885-ben 350 frt ,szövetségi kvóta" sem fedezte a tényleges költségeket. Az 1885. XII. 23-i választmányi ülésen a társulati titkár bejelentette, hogy tudomása szerint az MKFI rövid idő́n belül „összes munkálkodásainak eredményeit kizárólag a saját zászlaja alatt készül közrebocsátani”. A választmány láthatólag nem igyekezett az Intézetet erról lebeszélni, inkább arra törekedett, hogy az általa önállóan kiadandó Évi Jelentéseket is megszerezze tagjai számára, emellett továbbra is felajánlotta a Közlönyt „a m. kir. földtani intézet hivatalos közlönyéül”, valamint azt is, hogy az Intézet „,csere kötelezettségei számára a kelló példányokat ezentúl is kész örömest kiszolgáltatja" [16: 71-72]. Az 1886. II. 3-i választmányi ülésen már expressis verbis elhangzott, hogy ,a «Jelentések» kinyomatása terjedelmüknél fogva (...) egy idô óta oly mérvú financiális és szerkesztési nehézségekkel járt, melyeknek legyőzése sem a szerkesztốk, sem a társulati pénztár hatalmában nem áll". Végül az a megállapodás született, hogy az Intézet és a Társulat szövetségi viszonya továbbra is fennmarad, és így a Közlöny címlapján az „egyszersmind m. kir. Földtani Intézet hivatalos közlönye" kitétel is megmarad, de az Intézet Évi Jelentéseit saját neve alatt és költségén maga adja ki. A Társulat lemond a segélyrôl, de az Évi Jelentésekből saját tagjai és csereviszonyosai részére saját költségén különlenyomatokat készíttethet [16: 116-117]. A századforduló után megritkultak a Közlönyben publikált intézeti közlemények is, mindazonáltal a ,szövetségi viszonyt” jelző, idézett kitétel egészen 1949-ig megmaradt a címlapon (5. ábra).

\section{Konszolidált évek (1886-1918)}

1886-tól tehát a Földtani Közlöny megállapodott tartalmában, formájában és rendszerességében is. Megjelentetése annak ellenére nem jelentett állandósult gondot — mint a Társulat későbbi története során oly sokszor - , hogy költsége az évi kiadásoknak általában 40-60\%-át felemésztette. A Társulat ugyanis 1887-től biztosan számíthatott a kultuszminisztériumtól rendszeresen kapott 1000 frt (=2000 K) országos segélyre (vagyis állami dotációra), melynek összege 1907-ben 3000 K-ra nőtt [38: 67], 1910-tôl pedig a föld- 


\section{FÖLDTANI KÖZLÖNY \\ A MAGYARHONI FÖLDTANI TÁRSULAT FOLYÓIRATA EGYSZERSMIND \\ A M. KIR. FÖLDTANI INTÉZET HIVATALOS KÖZLÖNYE a) "ZIMÁNYI KÁROI.Y JUBILEUMI KÖTET".}
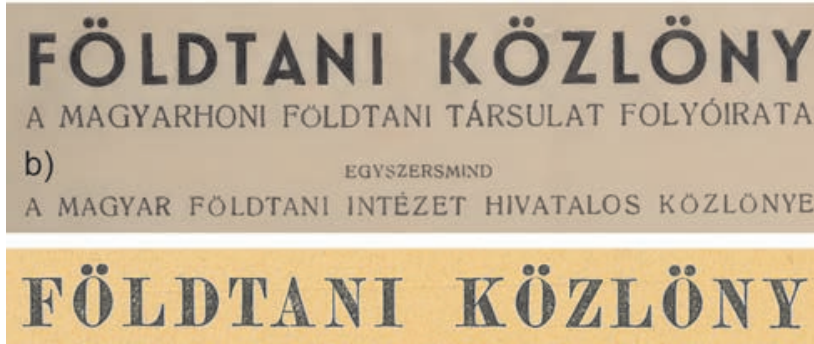

BULLETIN DE LA SOCIÉTÉ GEOLOGIQUE DE HONGRIE BULLETIN OF THE HUNGARIN GEOLOGICAL SOCIETY БЮЛЕТЕНЬ ВЕНГЕРСКОГО ГЕОЛОГИЧЕСКОГО ОГЩЕСТВА GEOLOGISCHE MITTEILUNGEN

\section{A MAGYARHONI FÖLDTANI TÁRSULAT FOLYÓIRATA}

ES

\section{AZ ALLAMI FÖLDTANI INTEZET}

c) HIVATALOS KÖZLÖNYE

5. ábra. A 23.-tól a 79. kötetig a címoldalon olvasható alcím tudatta, hogy a Földtani Közlöny egyben a Földtani Intézet hivatalos közlönye is. A felirat híven tükrözte az Intézet névváltozásait. a) Az Intézet eredeti neve a „m. kir.” (magyar királyi) jelzőkkel [62]. b) A Közlönynek a királyság idején (1943-ra) esedékes, de csak a köztársaság alatt (1948-ban) megjelent füzetének címlapján gordiuszi megoldással az 1943-ban használatos „királyi” és az 1948-ban használatos „állami” jelzők egyikét sem írták bele az Intézetnek a címlapra nyomott megnevezésébe [73/10-12]. c) Az Intézet 1946 utáni neve, érdekes módon a „magyar” jelző nélkül [77]

Figure 5. From Vol. 23 to Vol. 79, a subheading on the front cover announced that the Bulletin was also the official journal of the Földtani Intézet (Geological Institute). The inscription faithfully reflected the changes of the official name of the Institute. a) The original name of the Institute, " $m$. kir." is the abbreviation of "magyar királyi" (Hungarian royal) [62]. b) The last number of Vol. 73 of Bulletin was to be published in 1943, during the monarchy but was printed only in 1948, during the republic. As a Gordian solution neither of the terms "királyi" (royal) to be used in 1943 and "állami" (state) to be used in 1948 was included in the name of the institute printed on the cover [73/10-12]. c) The name of the Institute after 1946 with "állami" (state) instead of "királyi" (royal), interestingly here without the adjective "magyar" (Hungarian) [77]

múvelésügyi minisztériumtól további $4000 \mathrm{~K}$ államsegély érkezett [40: 643]. Mindez a tagdíjbevétellel együtt már megalapozta a Közlöny egyre bővülő terjedelemben és jó minőségben történő kiadását. Ennek ellenére többször viszszatérő panasz volt a terjedelem korlátozottsága. 1890: A kéziratok „bőségét alig bírta Közlönyünk, mely meg mindig nyög anyagi viszonyaink korlátoltsága alatt” [20: 109]. 1898: „Közlönyünk tavalyi [27] évfolyama nem is győzte a sok anyagot, dacára annak, hogy ez évben kedvezó anyagi helyzetünk megengedte Közlönyünknek a megszokottnál nagyobb terjedelmet adni” [28: 58]. 1907: „Sajnos, hogy pénzügyi helyzetünk nem engedte meg [a Közlöny] terje- delmének további emelését, mert a nyomdák ismeretes 15 százalékos díjemelése azt lehetetlenné tette" [37: 48]. Megemlítendő, hogy a nyomdaköltségekhez hozzájárult még az MKFI Évi jelentéseiből a tagok számára illetményként eljuttatott különlenyomatok ára is.

A rovatokat tekintve a lap gerincét az értekezések és rövid közlemények képezték, mellettük gyászjelentések és nekrológok is megjelentek. Az 1880-as évek közepétől az irodalmi ismertetések közül a bővebbeket az „Ismertetések”, a pársorosakat az „Irodalom” rovatba sorolták. A mai hírrovat elódjét a „Vegyesek”, „Különfélék”, illetve „Geológiai események" (1910-18) jelentették. Itt jelentek meg a társulat egyes hivatalos közleményei is, magukat a rendezvényeket a „Társulati ügyek” rovat mutatta be. (Részletesebben 1. A Földtani Közlöny szerkesztésére vonatkozó szabályok [46: 129-132].) Részben tárgyhiány miatt rövid életúnek bizonyult a Budapest geológiájáról 1910-ben [40] nyitott rovat. 1897-ben [27] jelentek meg az elsô - mai kifejezéssel élve - tematikus számok „A millenniumi év végén" címmel, a millenniumhoz és a millenáris kiállítás geológiai és montanisztikai részéhez, illetve 1896-os szakmai összejövetelekhez kapcsolódva (l. az Adattárat). 1900tól [30] kezdődően jelent meg az előző évi magyar geológiai irodalom repertóriuma. Az 1881-ben felállított társulati földrengési bizottság 1902-1906 [32-36] közt publikálta megfigyelési adatait, melyeket az MKFI pincéjében 1901ben felállított Bosch-féle ,strassburgi ingapárral” nyert. Az ábrák száma fokozatosan megnőtt, a legnagyobb terjedelmú kötetekben (az 1910-es évek elején) 60-70-et is elért (6. ábra). Az 1890-es évektől az ábrák közt már fotók is voltak.

1908-ban az elsố titkár szerint „tudományos életünknek egészségesebb mederbe való terelődését látjuk közlönyünkben meghonosodni azzal, hogy tudományos viták jelennek

2.

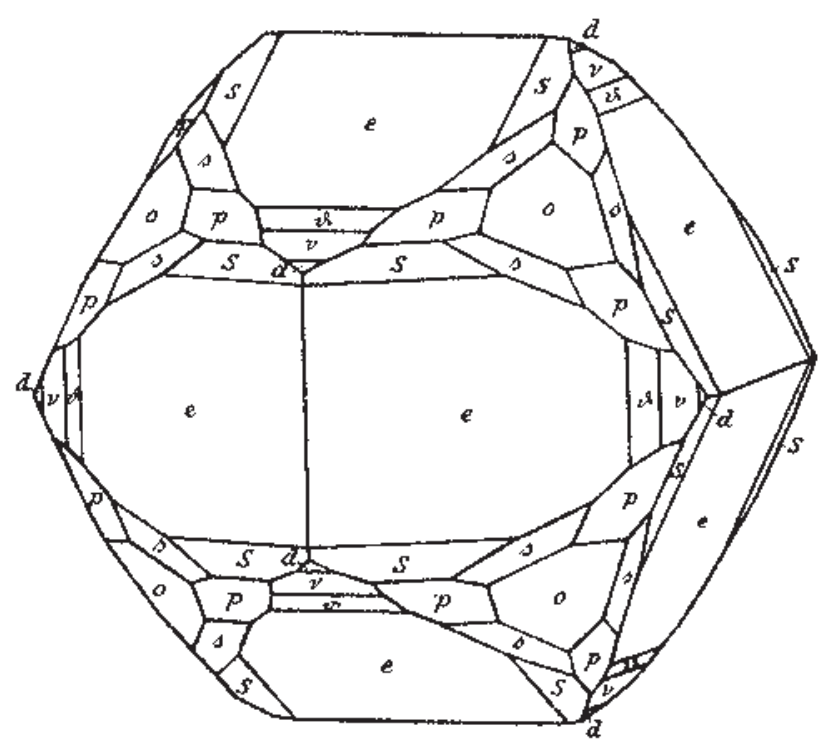

6. ábra. Kőnyomatos illusztráció a Földtani Közlöny 35. évfolyamából (piritkristály, MAURITZ Béla rajza) [35: III. tábla, 2. ábra]

Figure 6. Lithography illustration from Vol. 35 of the Bulletin (pyrite crystal, drawing by Béla MAURITZ) [35: Plate III, Fig. 2] 
meg. Eddig ugyanis a tudományos vitáknak hiánya, vagy ritka jelenségként való megjelenése, megbénította a magyar geológiai irodalmat" [38: 71]. Ugyanazon évben a 38/5. szám - a Szabó-szikla emléktáblájának leleplezése kapcsán kiadott „Szabó-füzet” volt a Közlöny első emlék- avagy dedikált száma. Ennek megjelenését az MTA 1000 K segéllyel támogatta [39: 52]. 1910. III. 20-án a választmány kimondta, „hogy nem szívesen látja azt, ha a szerző azt a munkáját, amely a Földtani Közlönyben megjelenik, ugyanabban a terjedelemben és kidolgozásban más hazai vagy külföldi szakközlönyben is kiadja. Mégis mérlegelve bizonyos eseteket, nem zárkózik el mereven az elől sem, hogy a szerző munkáját a Földtani Közlönyben való megjelenése után más helyen is közölhesse", feltéve, ha ennek tényét feltünteti [40: 217-218].

A ,konkurens" szaklapokat tekintve megemlítendő, hogy az MKFI 1914-től Geologica Hungarica. Series Geologica címmel terjedelmesebb értekezéseket tartalmazó idegen nyelvú sorozatot indított. 1894-ben megszúnt az MTA Értekezések a természettudományok köréból címú periodikuma, az MNM természetrajzi osztályainak kétnyelvú folyóirata pedig 1902-től Annales Historico-Naturales Musei Nationalis Hungarici néven jelent meg.

1910-ben a korábbi földrengési bizottság mintájára a választmány — tagja, Lóczy Lajos javaslatára — megalakította a Barlangkutató Bizottságot [40: 62], melynek közleményei 1910-12 között [40-42] szintén a Közlönyben kaptak helyet. 1913-ban a bizottság Barlangkutató Szakosztállyá alakult, és „Barlangkutatás/Höhlenforschung” néven saját, elvileg évente négy ízben megjelenô, kétnyelvű folyóiratot adott ki. Ez volt az MFT elsô önálló szakosztályi kiadványa, mely ilyen formában a Szakosztály feloszlásáig [57: 89], egyben a Barlangkutató Társulat 1926. II. 20-án történt megalakulásáig 13 kötetet ért meg (ezekból a 10-13 összevonva jelent meg). 1903-ban [33] megjelent a Közlöny következő repertóriuma, a 13-30. kötetek tartalommutatója CHolnoky Jenő szerkesztésében ([R2] az Adattárban). A 33/7-9. füzet ismét ,tematikus szám volt”, a Bécsben tartott IX. Nemzetközi Geológiai Kongresszus utánra tervezett alföldi és aldunai kirándulásra írt kirándulásvezetőket tartalmazta, miután a kirándulások elmaradását követően engedélyezték a minisztériumi támogatás felhasználását a vezetôk kinyomtatására [33: 78, 33: 485, 34: 74-77].

1908 és 1914 között, részben a Barlangkutató Bizottság közleményei miatt is, a Közlöny egy év kivételével végig 600 oldal fölötti vaskos kötetet tett ki, 1912-ben elérve minden idők legnagyobb, mutatók nélkül 988, azokkal együtt 1028 oldalas terjedelmét, annak ellenére, hogy 1904 óta a cikkek hosszát két ívben maximálták, és a két ív fölötti rész nyomdaköltségét a szerzói tiszteletdíjból fedezték [34: 250]. A Közlöny megjelentetése, bár költsége ugyanezen időszakban az évi társulati kiadás 45-70\%-át tette ki, mindazonáltal nem forgott veszélyben. Az 1908-ban megkezdett szisztematikus tagtoborzásnak és az 1912 végén már 114 tagú Barlangkutató Bizottság megalakulásának is köszönhetően a társulati tagság az 1910-es közel 400-ról 1913-ra 730-ra nőtt, a Hidrológiai Szakosztály megalakulása után, 1917-ben pedig elérte a 755-öt. Magánszemélyek mellett igen sok jogi személy is tag lett. LócZY Lajos például kieszközölte, hogy a földmúvelésügyi miniszter az összes állami erdőigazgatóságot, erdőhivatalt és erdőfelügyelőséget a tagok sorába léptette, s így 90 állandó taggal szaporodott a Társulat [46: 28]. Azt nem sikerült elérni, hogy az állami középiskolákat beléptessék [44: 515], de 1915-ben az iskolák fele így is a Társulat tagja volt [46: 28]. (A tagság ezen „felhígulása” volt egyébként a VADÁsz Elemér, Kormos Tivadar és BALLENEGGER Róbert nevével fémjelzett 1918/1919-es ,társulati forradalmárok” által javasolt alapszabály-változtatások egyik hivatkozási pontja. Késóbb MAURITz is helytelenítette azt, hogy „a régebb múltban a titkárság arra törekedett, hogy a tagok száma minél nagyobb legyen, de nem nagyon vizsgálta azt, hogy a tagokat milyen erkölcsi, érzelmi vagy egyéb kapcsolatok kötik a Társulathoz" [55: 248-249].)

A befolyt tagdíjak ezen időszakban 4000 és $5800 \mathrm{~K}$ között mozogtak, és az évi 50-60 előfizető díjaival (550 K körül), valamint a $7000 \mathrm{~K}$ állami dotációval együtt meghaladták a Közlöny 9-12 000 K között változó közvetlen kiadási költségét. A választmányi üléseken több ízben tesznek említést SEMSEY Andornak egyes cikkek kinyomtatására fordítandó adományáról is [pl. 40: 642], 1910-ben ez összesen 2340 K volt, azonkívül egyes cikkek megjelentetésére olykor az állam és egyes intézmények, illetve társulatok is áldoztak több száz koronás összegeket [1. pl. 41: 304-305]. A Közlöny példányszáma a taglétszám növekedése miatt az 1908-as 650-ról 1914-re 1100-ra nőtt [40: 62, 46: 29]. Vélhetôleg a Közlöny terjedelemnövekedése miatt is, illetve ,,a titkárság helyzetét egyes felolvasók netalán teljesíthetetlen követeléseivel szemben megkönnyítendő", SCHAFARZIK Ferenc társulati elnök javaslatára 1913. IV. 2-án szerkesztőbizottságot alakítottak (részletesebben 1. az Adattárban) [43: 108, 356].

Az első világháború hatásai természetesen a Földtani Közlönyt is érintették, aminek elsô jele az volt, hogy az olvasót utoljára 1913-ban segítette a betûrendes tartalommutató (index). Az 1905-14 közt 660 oldalas átlagos terjedelem az 1915-1918-as években 2/3-ára (410 oldalra) esett vissza. Költségcsökkentési céllal 1915-től kezdve legfeljebb évi négy (rendes) folyóiratszám jelent meg — és ez mindmáig így van. A gondokat egyik oldalról a bevételek visszaesése okozta: a $7000 \mathrm{~K}$ államsegély 1914-ben $6500 \mathrm{~K}$ ra csökkent, 1915-ben mindössze $2500 \mathrm{~K}$ volt; az utolsó békeév 5054 K tagdíjbevétele 1914-re 4360, 1915-re 3920 Kra esett, a Társulat vagyonát pedig csaknem $7000 \mathrm{~K}$ adóssággal terhelte meg a hadikölcsönök jegyzése. Bár 1916-ban $6000 \mathrm{~K}$, majd 1917-ben ismét $7000 \mathrm{~K}$, 1918-ban pedig $11000 \mathrm{~K}$ (!) államsegély érkezett, a másik oldalon még mindig ott volt a nyomdaköltségek állandó növekedése (1915. XII. 14-én 30\%, 1916. XI. 8-án 30\%; 1917. I. 1-én $40 \%$; 1917. IX. 15-én 25\%, 1918. III. 15-én 25\%, 1918. VI. 1jén 15\%, 1918. IX. 1-én 25\% [48: 292, 48: 400].

SCHAFARZIK Ferenc az 1916. II. 9-i közgyúlésen a szükséghelyzetben több lehetséges költségcsökkentési megoldást vázolt fel a Közlöny számára: a cikkek terjedelmi korlátozása; a népszerű cikkek és ábrák elhagyása vagy egy kü- 
lön kiadványban való megjelentetése (vagyis a Földtani Értesítô „feltámasztása”), a ,helyi jelentôségư” cikkekből teljes fordítás helyett csak kivonat közlése [46: 2-3]. SCHAFARZIK az 1916. III. 1-i választmányi ülésen is indítványozta a Földtani Közlöny szétválasztását egy tudományos és egy népszerű részre [46: 128]. MAURITz később úgy emlékezett vissza, hogy „,midôn a világháború előtt Társulatunkban, illetőleg a Földtani Közlönyben a népszerúsítő irányzat kezdett felülkerekedni, megint felmerült a gondolat, hogy a Földtani Értesítő újra életre keljen, de végül mégis csak az a vélemény alakult ki, hogy Társulatunk és a Földtani Közlöny maradjon meg eredeti rendeltetésénél, a földtannak és rokontudományainak tudományos múvelésénél, a népszerûsítést pedig végezze az arra hivatott Kir. Magy. Természettudományi Társulat" [55: 8].

Ezen ülésén a választmány ismét szerkesztőbizottságot alakított [46: 128] (1. még az Adattárban). SCHAFARZIK Ferenc és ScHRÉTER Zoltán részletes szabályzatot dolgozott ki a Közlöny számára, ezt a választmány 1916. IV. 5-én elfogadta. „A Földtani Közlöny szerkesztésére vonatkozó szabályok” bevezetője leszögezi: „Minthogy a Magyarhoni Földtani Társulat alapszabályszerú feladata a földtan és rokontudományainak múvelése és terjesztése, a Földtani Közlöny mindezen tudományágak szolgálatában áll. A szerkesztőség feladata gondoskodni arról, hogy valamely rokonszak a többi rovására túlsúlyra ne jusson és vigyázni arra, hogy az egyes füzetek tartalma változatos legyen $\mathrm{s}$ különösen, hogy a kevesebb tagtársunkat érdeklő rokonszakokból (pl. kristálytan, paleontológia) egy-egy füzetben több értekezés ne jelenjen meg. A Közlönyben a főszaknak, a geológiának, vezérszerepet kell biztosítani s ezért a földtani közlemények alkossák a Közlöny gerincét". Részben a már korábban kialakult gyakorlatot írásba foglalva részletekbe menően szabályozták a Közlöny szerkezetét, az egyes rovatok tartalmát, sorrendjét és betúméretet, sốt azt is, hogy mi kerülhet a Közlöny borítólapjaira „,a kiadványok jegyzéke, a tagsági díjak nyugtázása, valamint a vasúti menetrend is a borítékra valók, ahol csakis a m. kir. Földtani Intézet és a Magyarhoni Földtani Társulat kiadványai hirdethetôk. Esetleges megkeresésre - amint a múltban is történt — méltányos díjazás mellett egyes hirdetések mellékelhetők a Közlönyhöz”. Egy cikk továbbra is csak kivételesen haladhatta meg a két nyomtatott ívet, a többlet költségét pedig levonták a két ívért járó írói díjból [46: 129132]. 1916. VII. 7-én a választmány 20-25 ívre (320-400 oldalra) redukálta a 46. évfolyam oldalszámát [46: 297].

1917. I. 31-én a választmány javasolta a Hidrológiai Szakosztály megalakítását, ezt a II. 7-i közgyúlés elfogadta [47: 87]. Ezután rövid ideig (1918-1920) a Földtani Közlönyön belül újból egy „,belső társlap” különült el, a Hidrológiai Közlemények / Hydrologische Mitteilungen (7. ábra). Ennek kiválásával, hivatalosan 1921-tôl, ténylegesen 1928tól indult az MFT második szakosztályi szaklapja, a Hidrológiai Közlöny, melynek 1949-ig, az önálló Hidrológiai Társaság megalakulásáig 28 kötete jelent meg.

A világháború hétköznapjai a Közlönnyel kapcsolatos választmányi napirendi pontokban is tükröződtek, például

\section{FÖLDTANI KÖZLÖNY. HAVI FOLYÓIRAT}

\author{
KIADJA A MAGYARHONI FÖLDTANI TÁRSULAT. \\ gGYSZEREMIND \\ A MagYaR KIRALYI FÖLDTANI INTÉZBT HIVATALOS KÖZLÖNYR. \\ A HIDROLÓGIAI KÖZLEMÉNYEK \\ II. KÖTETÉNEK 1. SZÁMÁVAL. \\ SZERKEBZTI \\ D PAPP KÁROLY \\ RGYETEMI TANÁB, TÍRSULATI FÓTITKÁB. \\ NEGYVEN KILENCEDIK (XLIX.) KÖTET. 1919.

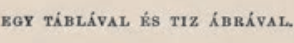

7. ábra. A Hidrológiai Közleményekre, a Földtani Közlöny „belső társlapjára” utaló alcím a 49. évfolyam címlapján [49: B1]

Figure 7. A subtitle on the front page of Vol. 49, referring to Hidrológiai Közlemények (Bulletin of Hydrology), published within the Bulletin of the Hungarian Geological Society [49: B1]

az olyasféle hírekben, miszerint, ,igazolta az elnökség a cenzúra előtt a Földtani Közlöny felelős szerkesztôjét, az alapszabályok 20. §-a szerint az elsőtitkárt, s helyetteséül a másodtitkárt" [47: 285]. Ennek nyomán jelent meg a Közlöny hátsó belső borítóján 1917-ben ,,a hatóságoknál bejelentett felelős szerkesztő" neve. A választmány 1918. V. 8-i ülésén NOPCSA Ferenc már az ügyben tett javaslatot, hogy ,,a Társulat jelentse be papírszükségletét gróf Teleki Pál úrnál, az Országos Hadigondozó Hivatal elnökénél, aki a hadügyminisztérium révén esetleg nemcsak papirost, hanem ólmot is szerez a Társulatnak" [48: 290]. TELEKI el is kezdett intézkedni ,a jövő évi papírszükséglet olcsóbb megszerzése ügyében”, mindazonáltal a választmány VI. 5-én úgy határozott, hogy ,a Földtani Társulat lehetôleg óvja meg önállóságát s közvetlen a kereskedelemügyi miniszter úrhoz forduljon a papír megszerzése ügyében”. A papírt 1200 példányra és 30 ívre (480 oldalra) igényelték, mert a taggyứjtési mozgalom 130 (!) új taggal gyarapította a Társulatot, és emiatt már 1918-ban 1200 példányt nyomtak a lapból [48: 292].

A 36000 ív papírra végül nem volt szükség, mert az összeomlás és a forradalmak miatt nemcsak a 49. évfolyam nem jelent meg 1919-ben [50: 67], hanem még az 1918. évi 10-12. füzetet [48/10-12] is csak 1920-ban nyomtatták ki. E füzet nyitó cikkének címe és sorsa is a történelem keze nyomát viseli magán. TREITz Péter „Magyarország morfológiai egysége" címú, térképmelléklettel ellátott értekezését [48: 357-380], amely az akkor még csak de facto megcsonkított ország természeti egységéról szólt, először a Tanácsköztársaság idején a tudományos társulatok direktóriuma vetette ki a füzetből ,azzal az indokolással, hogy a Tanácsköztársaság nem ragaszkodván a területi épséghez, olyan cikket nem közölhet, mely a magyarság uralmát tovább is fenn akarja tartani”. Majd Budapest megszállásakor jött a román cenzor, és persze ô sem engedte az értekezés kinyomatását. A Franklin-Társulat főszedője szerencsére elrejtette a szedést, és így a cikk 1920-ban megjelenhetett [50: 54]. További apró 
történeti érdekességként említjük meg, hogy a Magyarhoni Földtani Társulat és a Földtani Közlöny a 4. helyen szerepel a magyar békeküldöttség által a Szövetséges és Társult Hatalmak elé terjesztett ún. Bemutató jegyzékben található, a „Magyar tudományos egyesületek és intézmények, alapításuk éve, céljuk és szakfolyóirataik" címú, időrendi sorrendben összeállított listán (A magyar békeszerződés. A m. kir. külügyminisztérium kiadása, Budapest, M. kir. tud.egyetemi nyomda, 1920: 57).

\section{Küzdelmes idószak az I. világháború végétől a „fordulat évéig”' (1919-1948)}

A világháborús vereség, a forradalmak és az ellenforradalom megpróbáltatásai, a példátlan területi veszteségek ahogy az ország sorsára, úgy természetesen az MFT múködésére, és így a társulati közlöny megjelenésére is kihatottak. A hadikölcsönbe fektetett vagyonrész elvesztett, a maradékot elvitte az infláció, melynek közepette különösen nehéz volt a múködést fenntartani. Amint az 1930-as titkári jelentés rámutat, a pengő (P) bevezetésével, „1927 után a helyzet megjavult, de elvesztettük összes alapítványaink és értékpapírjaink értékét, úgyhogy tisztára szúkös bevételeinkre vagyunk utalva, ami meg is nyilvánul a Közlöny terjedelmében" [30: 144]. Ezen időszakban a Közlönyben nem nyomtattak ki részletes pénztári kimutatásokat, csak annyi ismeretes, hogy a bevételek 4000-8000 P, a kiadások 30007700 P között mozogtak. A ritka számszerú adatok szerint az 1918 előtti, megbízhatóan tervezhető, tekintélyes összegú segélynél jóval kisebb állami támogatás érkezett (1928-ban $1300 \mathrm{P}=$ aranyparitáson $1121 \mathrm{~K}, 1930$-ban $500 \mathrm{P}=431 \mathrm{~K}$ ), bár a közgyúlési beszédekből arra lehet következtetni, hogy az államsegélynek e periódusban is komoly szerepe lehetett a Társulat múködésében. Ezt az is valószínúsíti, hogy a hézagos adatokból kiindulva a tagdíjak, az egyéni (például a hivatalos pártfogótól, ESTERHÁZY Pál hercegtôl érkező) adományok, illetve a bánya- és iparvállalatok viszonylag rendszeres és az MKFI időnkénti támogatása összességében jóval alatta maradt a Társulat éves bevételének. A Közlöny megjelentetési költségeiról annyit tudunk, hogy 1926-ban az éves bevétel 75\%-át [57: 87], 1927-ben több mint 80\%-át vitték el [58: 141], vagyis több mint 6000 P-t, 1935-ban 4900 P-t (a bevétel 87, a kiadások 88\%-a). Ugyanebben az évben tagdíjból mindössze 1000 P folyt be. A bevételek csökkenése és kiszámíthatatlan alakulása magyarázza a Közlöny terjedelmének és füzetszámának erős visszaesését és fluktuációját, mely ezt az időszakot jellemezte.

$\mathrm{Az}$ anyagi alapok megrendülésének leglátványosabb jele az időbeli csúszások mellett az évi több füzet helyett az évenkénti egy kötetben (sốt 1921-22-ben összevont kötetként [51/52]) való megjelenés és a drasztikus terjedelmi visszaesés volt. Az 1923. IV. 3-i választmányi határozat egyébként a cikkek terjedelmét 8 nyomtatott oldalban maximálta és a fordítást is csak kivonatosan közölték, rajzokat pedig — a nagy költségre való tekintettel — ,csak a legszükségesebb esetben" [51/52: B2]. Különös egybeesés, hogy az utolsó „,békeévtized” 660 oldalas átlagáról az 1919_ 28 közötti évtized 200 oldalára zsugorodó Közlöny terjedelemcsökkenése arányaiban csaknem megegyezett az ország területi veszteségével. Ahogy MAURITz Béla fogalmazott 1925-ös közgyúlési beszédében: „Olyan ma a Földtani Közlöny, mint szegény hazánk, Magyarország: csonka” [55: 250]. Mindez bizonyos rovatok megszúnésével járt (csereviszonyosok listája, utoljára 1918-ban), mások évekig szüneteltek: a magyar földtani irodalom bibliográfiája (1918-23 [48-53] közt), ismertetések (1920-23 [50-53]), személyi hírek (1919-24 [49-54]), illetve a késóbbiekben is csak elvétve bukkantak föl (pl. a társulati tagok névsora: 1925, 1928, 1932 [55, 58, 62]). Szúkebbre szabták a társulati ügyek ismertetését is, így a választmányi ülések jegyzőkönyvei 1919 után már nem jelentek meg, és csak az MFT titkárságán voltak megtekinthetők. Évekig nem volt táblamelléklet vagy csak egy-kettő akadt, az ábrák száma 10-30 körül mozgott. A cikkek kétnyelvűsége azonban változatlanul megmaradt.

Visszatérve a konkrét eseményekre (8. ábra), 1919-ben „a Földtani Társulat direktóriuma semmit sem publikált, a kéziratokat érintetlenül, a szedéseket széthányva vettük át (...), azonban a direktórium a Barlangkutatás folyóirat 4068 K 50 f számláját kiegyenlítette" — jelentette PAPP Károly az 1919. XII. 3-i választmányi ülésen. Közölte, hogy „a Földtani Közlöny széthányt szedéseit összeállítva, az elmaradt füzeteket néhány hét leforgása alatt elkészíti” [49: 78-81]. Az 1920-ban esedékes 50. évfolyam címlapja szerint 1921-ben jelent volna meg, de ennek ellentmond, hogy a belső borítón egy 1922. márciusi dátummal aláírt közleményben mentegetőztek a szerkesztők: „Összes tagjaink és olvasóink bizonyára türelmetlenül várták a Földtani Közlöny ezen évfolyamát, mert mint 50-iket, valamilyen különös ünnepi mezben óhajtották viszontláthatni. Most pedig, hogy közkézre adjuk, épen az ellenkezőjét kell róla

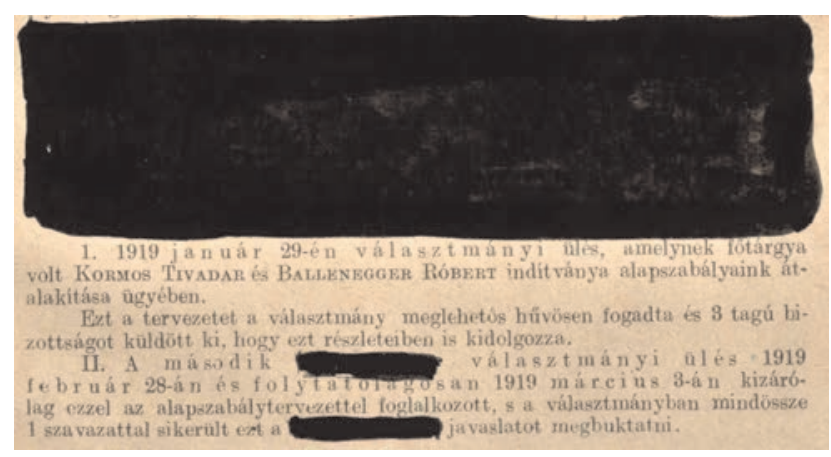

8. ábra. Amikor a múltat tussal akarták végképp eltörölni: az ELTE TTK Földtani Tanszékének könyvtárából származó 1920-as Földtani Közlöny egy lapjának részlete. Vélhetőleg az egykori 1919-es „társulati forradalmár” VADÁsZ Elemér 1946 és 1964 közötti tanszékvezetősége idején PAPP Károly 1919-es titkári jelentéséből a „reakciós” részeket tussal elfedték (a II. pontban a „„örvénytelen” minősítést húzták ki két ízben) [50: 55]

Figure 8. Obliterated past: Detail of a page from a copy of Vol. 60 (1920) of the Bulletin from the Library of the Dept. of Geology, Eötvös L. University, Budapest, containing the report of Károly PAPP, secretary, about the events of the year 1919 in the Society. Presumably when the department was chaired from 1946 to 1964 by Elemér VADÁSZ, one of the leaders of the 1919 "revolt" within the Society, the "reactionary" parts of the report were obscured by ink [50: 55]. 
megállapítanunk, mert nemcsak külső kiállításában, de méreteiben is tagadhatatlanul a mostoha időket tükrözteti vissza. (...) Kérjük tehát tagjainkat és olvasóinkat, hogy egy jobb jövő reményében elnézéssel legyenek a Földtani Közlöny hiányosságai és késedelmes megjelenése iránt és érdeklődésüket tôle ezután se vonják meg." A közlemény az évi tagdíj 50 K-ra történő emelésének bejelentése mellett [1. még 51/52: 8] a tagok és jóakarók erkölcsi és anyagi támogatását kérte a ,kétszer ad, ki gyorsan ad” mondást idézve — ekkor még természetesen latinul [50: B2]. (Az évenként következő további tagdíjemelésekról 1. az Adattárat.)

Az 51. és 52. évfolyam egy kötetben jelent meg 1923-ban részben takarékossági okokból, részben azért, mert 1924ben újból két évfolyamot kiadva tervezték az elmaradások behozását. „Hogy az elmaradt két évfolyamot egyáltalán kiadhattuk, az tisztán ez évben befolyt tudományt pártoló adományok érdeme. (...) A befolyt új tagdíjak, amelyeket a február 7-i közgyúlés állapított meg (...), bizony csak olyan csekély összeget tettek ki, hogy még a társulati ügyek postai és adminisztratív költségeit sem fedezték" — írták a szerkesztők borítólapi közleményükben [51/52: B2]. A kiadást leginkább a KLEBELSBERG Kunó kultuszminiszter által nyújtott $2640000 \mathrm{~K}$ állami támogatás és a szintén általa biztosított kedvezményes árú papír tette lehetővé [54: 123124]. 1924-ben újból $4380000 \mathrm{~K}$ államsegély érkezett [54: 131], ez az éves társulati bevétel csaknem 40\%-át képezte, vállalatok és magánszemélyek hasonló nagyságrendben adakoztak. Így is csak egy kötetet adtak ki, ezért a Közlöny még jó ideig egy év elmaradással küzdött. A felmerülő többletköltségek miatt arra még kevésbé volt mód, hogy a Közlöny ismét évi több füzetben jelenhessen meg [55: 248]. A titkárok korábbi több száz aranykoronás díjazása már a múlté volt, mindazonáltal „,mindennemü irodai munkát, a számos reklamációra való választ, de még a címszallagok írását is" maguk végezték el, a kézbesítést pedig lehetőleg az egyetemi altisztekkel oldották meg stb. [55: 248-249].

Az infláció végével és a pengő bevezetésével fölcsillant a remény, hogy ,nincs messze az idő, midőn a Földtani Közlöny ismét régi terjedelmében fog megjelenni s megszűnnek a felette kellemetlen korlátozások is." [56: 137]. A tagdíjat 8 P-ben állapították meg, ez aranyparitáson átszámolva 6,9 K-nak felelt meg. A társulat 75 éves fennállását ünneplő, 1925. évi 55. kötet, melyet TELEGDI RoTH Károlynak ajánlottak, a régi időket idéző 411 oldalas terjedelemben jelent meg, és az 1927. évi [57] Közlönyt már füzetekben tervezték kiadni [57: 87]. Végül két füzetben jelent meg, ebből az elsô még valóban 1927. december elején [58: 141], de aztán (1932-vel bezárólag) visszaállt az egyfüzetes kivitel, és a terjedelem is visszaesett valamivel 250 oldal fölé. Az 1928-as kötet már ismét késett, részben elég szokatlan okból: sikerült egy igen jó árajánlatot kínáló új 1920, a Franklin Társulat elhagyása óta immár a harmadik — nyomdát találni, ez azonban a váci fegyintézeté volt, és az igénybevételéhez késő őszig kellett várni az igazságügyminiszter engedélyére. Emellett ugyanekkor nyomták ki az új szakosztályi folyóirat, a Hidrológiai Közlöny elmaradt nyolc évfolyamát [59: 79-80]. Az 1931. II. 4-i közgyúlésen ismét arról esett szó, hogy ,,anyagi helyzetünk nagyon szomorú. Csak a legnagyobb nehézséggel tudjuk elteremteni azokat az összegeket, amelyek a Földtani Közlöny kinyomtatására szükségesek" [61: 119].

Fontos változást jelentett, hogy 1931-től [61] megszúnt a tanulmányok kétnyelvú közlése, a cikkek vagy magyar vagy idegen (főleg német) nyelven jelentek meg, ennek függvényében idegen nyelvú (német) vagy magyar kivonattal. Ekkor a külön „Supplement” is megszúnt, de 1940-től [70] visszaállították, és a német nyelvú cikkeket, illetve a magyar nyelvú cikkek német kivonatait ismét a magyar nyelvúektől elkülönítve közölték. Az 1931. évi [61] kötet 124 oldalával amúgy negatív rekordot állított fel, az 1932. II. 1-i közgyúlésen el is hangzott, hogy ,,az 1931. évről visszamaradt anyagi teher miatt az elmúlt évben kiadott 61. kötete a Földtani Közlönyének jóformán csak füzet-számba ment, terjedelme 8 ív volt." A Társulatot ez alkalommal is a kultuszminisztérium segítette ki a bajból, de több iparvállalat is összesen 732 P-t adományozott [63: 199].

A Földtani Közlöny terjedelme csak 1934-től, a nagy gazdasági világválság elmúltával stabilizálódott 300 oldal fölött, és ekkortól ismét évi négy szám jelent meg. A lap jobban illusztrálttá is vált, az ábrák száma 1933-tól elérte (9. ábra), olykor meg is haladta a korábbi ,rekordot” (pl. 1933: 87, 1937: 94 ábra), és ekkorra az ábrákhoz 10-20, sốt 1943ban 61 fotótábla járult. 1942-ben és 1943-ban számos térképmelléklet is bővítette a terjedelmet. Az „Ismertetések” rovat azonban 1932-39 között — immáron nem terjedelmi, hanem nyilván koncepcionális okokból — ismét szünetelt. Az 1930-as évek második felében a vállalatok 600-ról 1000 P-re növekvô mértékú adománnyal járultak hozzá a Társulat 6000-7000 P évi bevételhez, és EsTERHÁzy Pál herceg, a Társulat hagyományos pártfogóját adó ESTERHÁZY család feje is rendszeresen támogatta a Társulatot. Mindazonáltal a Közlöny helyzetének javulása valószínúleg nagyrészt a közgyúlési beszámolókban nem számszerúsített állami támogatásnak volt köszönhető. Az MFT anyagi viszonyainak konszolidálódását mutatta, hogy 1936-ban újraindult a Földtani Értesító, mely már az első évében 700 [37: 88],

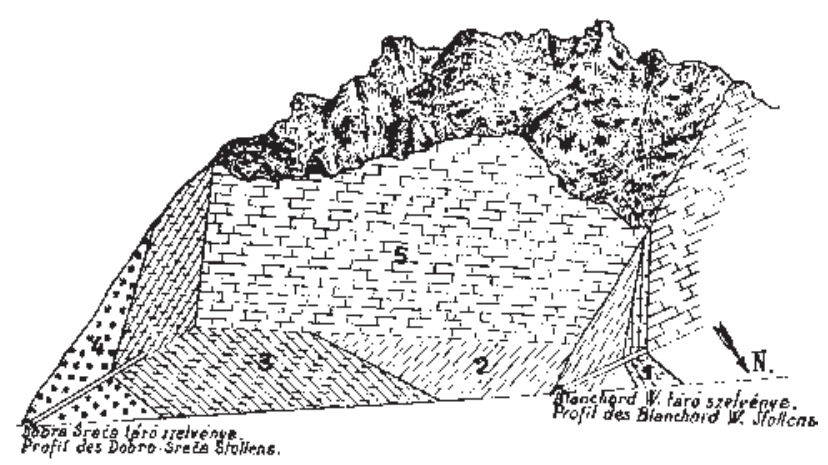

9. ábra. Egy érdekes vonalas ábra a Földtani Közlöny (folyamatos ábraszámozású) 64. évfolyamából (földtani szelvény két majdanpeki [ma Szerbia] bányavágat közt, KÁPOSZTÁs Pál rajza) [64: 209, 23. ábra]

Figure 9. An interesting linear figure from Vol. 64 of the Bulletin (with consecutively numbered figures; geological section between two galleries at Majdanpek [now Serbia], drawing by Pál KÁPOSZTÁS) [64: 209, figure 23] 
1939-ben pedig 823 [70: 34] előfizetôt vonzott (éves előfizetési díja $2 \mathrm{P}$ volt). Az évi négy füzetben megjelenő kiadványnak csak a neve volt azonos 1880-82 közt megjelent elődjéével, ugyanis attól eltérôen kizárólag tudománynépszerúsítő cikkeket és híreket közölt. Ennek ellenére e lap is gondokkal küzdött: Több ízben sem sikerült elérni, hogy az állami iskolák megrendeljék [68: 84], [69: 67]. Több mint 70 levelet írtak hirdetések érdekében, de azok úgyszólván mind eredménytelenek maradtak, csak két-három esetben sikerült személyes kapcsolatok révén néhány hirdetést szerezni [68: 84]. Ebben az időszakban sûrûn változtak a társulati kiadványokat készítő nyomdák, köztük több vidéki vállalkozás is volt (1. az Adattárat), a lapok a leghosszabb ideig (1932-41) a Mérnökök Nyomdájában készülttek. A B5-höz közeli formátum változatlan maradt.

A Társulaton kívüli kiadványokat áttekintve először egy olyan új „konkurenst” kell megemlíteni, melynek megjelenését MAURITz Béla elnök két közgyúlési beszédében is kárhoztatta, az anyagi erôk szétforgácsolására vezető törekvést látva benne. Először 1924-ben említette az ,efemer, bizonytalan jövőjư” folyóiratot, melyet ,békés viszonyok között” örömmel üdvözölt volna [54: 123], de csak 1925-ben nevezte meg a — PAPP Károly az MFT volt elsô titkára által életre hívott — Földtani Szemlét, ,,mely csaknem kizárólag a kultuszkormány állami támogatásából tudott megjelenni. Ha azonban abban az anyagi segítségben a Földtani Közlöny részesült volna, akkor Közlönyünk utolsó három kötetének nem kellett volna annyira szerény méreteket öltenie" [55: 252]. Az inkriminált lap valóban csak epizódszereplő volt a hazai földtani folyóiratok közt, első kötetének 6 füzete 1921 és 1943 (!) közt jelent meg a 2. — egyben utolsó — kötet egyetlen füzete pedig 1944-ben, és ez is szerkesztője, PAPP Károly 25 éves tanári jubileumát ünnepelte(!). A MKFI Geologica Hungaricájának nagy kihagyásokkal megjelenő Series Geologicájához 1928-ban csatlakozott a jóval súrúbben megjelenő, szintén idegen nyelvú Series Palaeontologica. Az MTA lapjai közül a Mathematische und Naturwissenschaftliche Berichte aus Ungarn 1931-ben, a Mat(h)ematikai és Természettudományi Közlemények 1944-ben megszűnt.

A II. világháború alatt újra csökkenni kezdett a füzetek száma, bár ez a terjedelmükre, érdekes módon, nem hatott ki, talán azért is, mert pl. az 1943-as kötet nyomdaköltségeit nagyrészt PAPP Simon, a Magyar Amerikai Olaj Rt. (MAORT) vezérigazgatója fizette. Az 1943. évi 4-9. füzet megjelenése után a lap évekig szünetelt. Az 1946. II. 6-i közgyúlésen az hangzott el, hogy „,másodelnökünk, Tasnádi Kubacska András [természettudományi múzeumi] főigazgató úr nagylelkúségének köszönhető, hogy bár kisebb terjedelemben, de rövidesen megjelenik a Közlöny 75-ik évfolyama" [75/76: 111]. Rá egy évre már azt kellett az elsô titkárnak bejelentenie, hogy ,az 1946-os infláció irama, amely az év elején hirtelen meggyorsult, az árak szorzószámának kéthetenként, hetenként, majd a nyár folyamán már végül is naponta változó tendenciája minden ebbéli reményünket elsöpörte" [77:85]. A Közlöny végül elég sajátos formában indult újra. Két összevont kötet jelent meg, ezeket három évre (1944/45 és 1945/46) keltezték, viszont négy kötetszámot viseltek (73/74 és 75/76), noha a 73. kötet elvileg az 1943. évi volt. Az első összevont kötet különös számozása mögött talán az rejlett, hogy kinyomtatásakor, 1947ben a 73. (1943. évi) kötetből az utolsó (10-12.) füzet még nem jelent meg (végül azonban 1948-ban az eredeti füzetszámozással kiadták, csakúgy mint az 1942. évi tartalommutatót is). 1945-46-ban a Földtani Értesítố is szünetelt.

A Közlöny 1941-47 közti kötetei az I. világháború utáni évekből ismert szimptómákat mutatták: az illusztrációk számának drasztikus visszaesése, az ismertetések (1944-46) [73/74-75/76], a magyar földtani irodalom bibliográfiája (1941-46) [71-75/76] kimaradása, a társulati ügyek visszaszorulása (1941-47) [71-77]. Az 1920-as évekbeli visszaesés korszakától eltérốn most az idegen nyelvû tartalom aránya is erőteljesen csökkent (20-30\%-ról 5-10\%-ra), annak ellenére, hogy a Földtani Közlöny címe alatt az 1944/ 45-ös [73/74] évfolyamtól kezdve már ötnyelvú felirat hirdette, hogy az MFT folyóiratáról van szó (10. ábra). Már az, hogy ebben a német szöveg volt az utolsó, érzékeltette, hogy

\section{FÖLDTANI KÖZLÖNY}

BULLETIN DE LA SOCIÉTÉ GÉOLOGIQUE DE HONGRIE BULLETIN OF THE HUNGARIAN GEOLOGICAL SOCIETY БЮ.ЕТЕНЬ ВЕНГEPCКОГО IЕОАОГИЧЕСКОГО ОБЩЕСТВA GEOLOGISCHE MITTEILUNGEN

LXXIII-LXXIV. 194445

10. ábra. A Földtani Közlöny 1944/45-ös összevont évfolyamának ötnyelvű címfeje [73/74 [!]: 1]

Figure 10. Title head in five languages from the first page of the combined volume of 1944/45 of the Bulletin [73/74 [!]: 1]

az idegen nyelvú tartalom elsöprő német túlsúlya megszúnt, és az idők változását tükrözve az 1945/46-os évfolyamban megjelent az elsô orosz kivonat is.

Az 1948-as kötet már újból több mint 200 oldalas volt, a szünetelő vagy karcsúsodott rovatok visszatértek, illetve ismét bővebb terjedelmet kaptak. Abban az évben az egyes minisztériumok 13 000, az Állami Szénbányászati Igazgatóság 24 000, a MAORT 1500 forint (a továbbiakban: Ft) támogatást nyújtott [79: 5], ez 1938. évi értéken mintegy 8500 pengőnek felelt meg, tehát meghaladta az akkori átlagos éves társulati összbevételt. Az évfolyam „A Magyarhoni Földtani Társulat alakulásának századik évében, 1848-1948” felirattal jelent meg, ugyanis a forradalom centenáris évében az MFT ,hivatalos születési évét" az eredetileg tervezett (1848. VIII. 18-19i) alakuló ülésnek a ténylegesen megtartotthoz (1850. VII. 6.) képest ,jobban csengő" évszámára tekintettel áthelyezték 1848-ra (és ez azóta is így maradt). Az MFT-nek a jubileumi évben a tudományos és szakmai társulatok gleichschaltolása keretében csatlakoznia kellett az akkor alapított Múszaki és Természettudományi Egyesületek Szövetségéhez (MTESZ). Az MFT (párt)állami kontroll alatt töltött négy évtizede új fejezetet nyitott a Közlöny történetében is. Ennek egyik első, még a Közlönyön kívüli jeleként az 1948-as összevont —és a meg nem jelent 1945-1946-os évfolyamokat is beszá- 
molva a 13. számot viselő - kötettel megszúnt a csak az előző évben újraindult Földtani Értesítô. E lapra ugyanis SzUROvy Géza szerkesztői előszava szerint — csak az „új idők új szellemének megvalósulásáig" volt szükség. A Földtani Értesítő profiljába illő cikkekre a szerkesztői iránymutatás szerint az átszervezett Természettudományi Társulat Természet és Technika címú folyóirata — a Természettudományi Közlöny utódlapja — várt. Az „új idők új szellemét" jól illusztrálta az előszóba beemelt GERŐ Ernő-idézet első mondata, amely szerint ,,tudósaink magukra vannak hagyatva, és a tudományos munka még szervezésre vár" [FÉ.13: 1]. A Földtani Közlöny következő évtizedei ezen államilag patronált, központosított és felülről szervezett tudományos élet áldásait és átkait tükrözik.

\section{Az ,,államosított’’ Földtani Közlöny (1949-1989)}

A szocialista állam 1949-re ellenőrzése alá vonta a földtudománnyal összefüggő gazdasági szereplők, az oktatási és kutatási intézmények, szakmai és tudományos egyesületek tevékenységét is. A nyersanyagtermelésnek csaknem a rendszerváltásig élvezett állami prioritása a nyersanyagkutatás „háttértudományaként” számon tartott földtudományoknak fontosságot és az utolsó évekig biztos anyagi hátteret adott, valamint állami odafigyelést biztosított annak minden elónyével és hátrányával. Az MFT tagságával szembeni állami elvárás — az 1948. II. 11-i közgyúlésen a MTESZ-hez való csatlakozás bejelentése kapcsán elmondott társulati titkári beszéd tanúsága szerint — az volt, hogy ,a földtani és bányászati kutatás szervezett és céltudatos folytatásával hozzájáruljunk az ország ásványi nyersanyagszükségletének biztosításához és ezen keresztül mi is megtegyük a magunkét a szocializmushoz vezető út kiépítésén hazánk és népünk javára”. Az ugyanekkor elhangzottak szerint a Társulat „cserében” a többek között „nemzetközileg elismert folyóiratának és kiadványainak fönntartását és kiadásának biztosítását" várta [78: 218]. A Közlönyt - mely éppen kétnyelvúségének e korszakban lezajlott megszüntetése miatt egyre kevésbé volt nemzetközileg elismert - 1986-ig tartotta markában avagy hordozta tenyerén a szocialista állam, amely a nyolcvanas évek közepétől már egyre kevésbé nyúlt a zsebébe, hogy biztosítsa az anyagi gondok nélküli megjelenést, mely kétségkívül előnyösen eltért az előző — és a következő — korszakban tapasztalt állandó bizonytalanságtól. Az MFT állami támogatásának zöme nem közvetlenül, hanem az állami vállalatok jogi tagdíján keresztuil érkezett. 1958-ban az állami támogatás 15 000, a jogi tagdíj 24 000, 1959-ben 22 000, illetve 46000 Ft volt [90: 264].

\section{A Közlöny intézményesedése: a VADÁSz-éra (1949-1967)}

Az immáron nem az állami tudományos intézményrendszerbe betagolt MFT kiadásában megjelenô Földtani Közlöny 1949. évi [79.] kötetének címlapján a meglepett olvasó ismét „A Magyarhoni Földtani Társulat alakulásának száza-

\section{A. MAGYARHONI FÖLDTANI TARSULAT \\ ALAKURASÁNAK SZÁZADYK ÉVÉBEN $1848-1950$}

BUDAPEST 1949.

KIADJA A MOSZAKI ES TERMESZETTUDOMÁNYI EGYESOLETEK SZOVVETSEGE

11. ábra. Részlet a Földtani Közlöny 1949. évi (79.) kötetének borítójáról a három évig tartó centenárium paradoxonját hirdető felirattal. A kiadó (már és még) a Mủszaki és Természettudományi Egyesületek Szővetsége [sic!] [79: B1]

Figure 11. Detail from the front cover of Vol. 79 of the Bulletin, 1949 (79), with a caption proclaiming the centenary of the Society. This volume was already published by the Federation of Technical and Scientific Societies [79: B1]

dik évében” felirattal találkozott, melyet az ,1848-1950”[!] évszámok egészítettek ki (11. ábra). A három évig tartó centenárium paradoxonja a fentebb említett „forradalmi időszámítás" következménye volt. A korra jellemző állandó változások és átszervezések lenyomataként egyébként az 1949-es és az 1951-es füzetek mindegyike tartamilag vagy tipográfiailag eltérő címlapot viselt, ami már csak azért sem meglepő, mert az 1951-es négy füzet három különböző nyomdában készült. 1950-tôl egyébként már ismét évi négy füzet jelent meg, ami VADÁsz elnöki megnyitója szerint „elengedhetetlen előfeltétele a Társulat célját tevő szaktevékenységnek s összetartója a földtan szakmunkásainak" [79: 4-5]. A négy füzet 1953-ig még formailag havi számozást viselt (1-3, 4-9 stb.), 1954-től már 1-től 4-ig számozták őket, de 1969-ig még a címlapukon viselték az adott negyedév hónapneveit (,,január-március" stb.). Lényegesebb volt az a kedvezô tördelési változás, hogy a korábban folytatólagosan következő cikkek 1949-től már kivétel nélkül új oldalon kezdődtek, 1952-től pedig megjelent a cikkek felett a szerző(k) nevét és a (rövidített) címet tartalmazó fejléc. 1949-re pótolták négy régebbi évfolyam tartalomjegyzékét is [80: 222].

A ,rendszerváltozásnak” olyan látványos elemek mellett, mint az 1950-es évek elején olykor a tudományos tartalom elé biggyesztett politikai vezércikkek, vagy az 1950ben az üres lapaljakat díszítő Rákosi-idézetek, kevésbé szembeötlő következményei is voltak. Némelyikük évtizedekig továbbélt, mint például a kivonatoknál az orosz nyelv erőltetése és a politikailag legkevésbé ,kompromittált” nyugati nyelv, a francia előnyben részesítése a némettel és az angollal szemben. (A szerzői útmutató az orosz fordítás részére külön rövid tartalmi kivonatot kért, és leszögezte, hogy „az orosz kivonaton kívül idegen nyelvként elsősorban a francia jön tekintetbe”.) Ez utóbbiban talán az MFT-re és különösen a Földtani Közlönyre két évtizedig meghatározó befolyással bíró VADÁsz Elemér személyes beállítottsága is tükrözôdött. Így aztán 1950-től 1989-ig a tartalomjegyzék alcímei magyar, orosz és francia nyelvúek voltak. Az 1966ig a belsô borítón olvasható szerzối útmutató iránymutatása szerint a külföldi könyvismertetéseknek elsősorban a rendelkezésre álló szovjet irodalmat kellett volna tárgyalniuk.

A fentebb említett felszíni jelenségek mögött alapvető 
változások húzódtak meg. A mindaddig az MFT saját lapjaként megjelenô folyóirat a társulat állami kontroll alá helyezése után előbb a MTESZ kiadványa lett, de már az 1949. évi 5-8. számot a Tudományos Folyóiratkiadó Nemzeti Vállalat jelentette meg, majd 1950 második félévétől a Nehézipari Könyv- és Folyóiratkiadó Vállalat következett. Megváltozott a szerkesztés gyakorlata is. Korábban a folyóiratot az MFT első és másodtitkára szerkesztette. A 77-79. kötetek felelős szerkesztôje viszont VADÁsZ Elemér, a letartóztatott PAPP Simont helyettesítô ügyvezető (al)elnök, majd megválasztott elnök volt, mellette a társulati titkárok voltak a szerkesztók. 1950-51-ben [80-81] egy időre KERTAI György (fő)titkár lett a felelős szerkesztő, a munkáját segítő (technikai) szerkesztő, JAKUCS Lászlóné (késôbb VÉGH Sándorné) NEUBRANDT Erzsébet 1965-ig látta el e feladatot. 1950 és 1954 között a felelős szerkesztő személye többször is változott. A később sokak által ,geocézár” néven aposztrofált VADÁsz Elemér (12. ábra) csak 1954-től lett újra felelős szerkesztő, de szakmai befolyása nyilvánvalóan ez előtt is kiterjedt a Közlönyre. A szerkesztésben fontos újítás volt, hogy az 1949-es közgyưlésen szerkesztôbizottságot választottak, melynek 11 tagja ekkor a következő szakterületeket képviselte: ásványtan (1), kőzettan (2), teleptan (1), földtan (3), őslénytan (2), alkalmazott földtan (1) és geofizika (1) [79: 128]. Ez a szerkesztőbizottság a korábbiaktól eltérôen nem volt efemer jellegú, bár tevékeny-

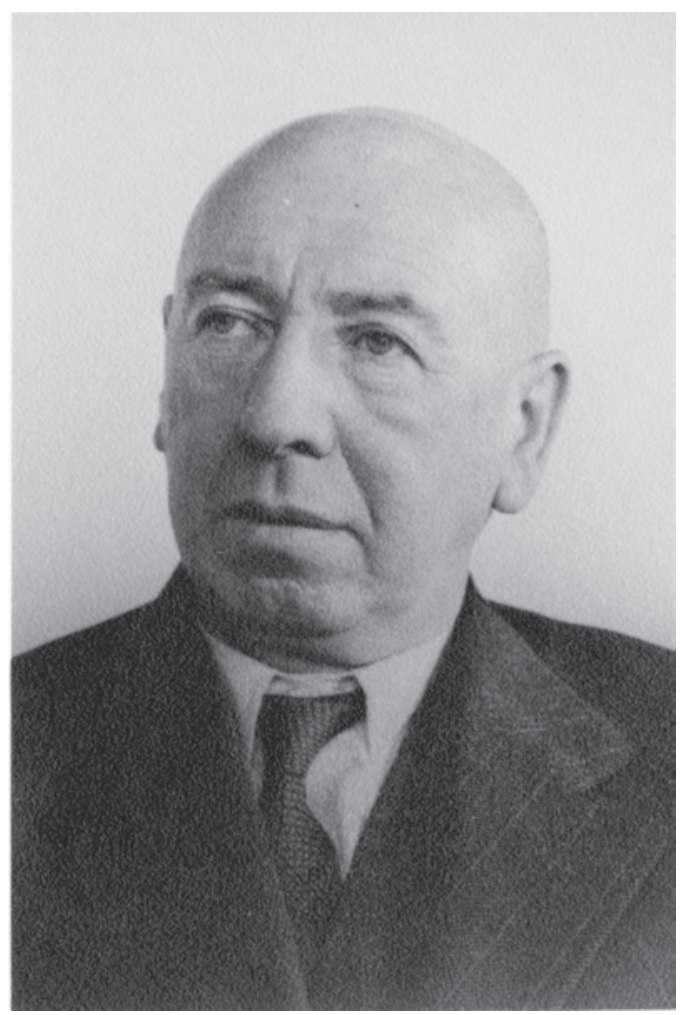

12. ábra. VADÁSZ Elemér (1885-1970), a Földtani Közlöny felelős szerkesztője (megszakitásokkal) 1945 és 1967 között (Fotó a Magyar Bányászati és Földtani Szolgálat Tudománytörténeti Gyüjteményéből)

Figure 12. Elemér VADÁSZ (1885-1970), responsible editor of the Bulletin (between 1945 and 1967, with interruptions). (Photo by courtesy of the Science History Collection of the Mining and Geological Survey of Hungary) sége hosszú ideig formális maradt, az érdemi döntéseket a (felelős) szerkesztő, illetve a főszerkesztő hozta. A lap szerkesztése lényegében azóta is e keretben zajlik, csak a felelős szerkesztő státusa változott, illetve 1997 óta főszerkesztő áll a folyóirat élén (l. az Adattárat is). Valószínúleg az MFT kiadói státusának megszúntével párhuzamosan a Közlöny tagilletményi státusa is megszúnt, de a Társulat tagjai a tagdíjukkal együtt jelentős kedvezménnyel fizethettek elő rá [85/2: B4, 86/2: B4, 92: 367, 93: 422, 97: 360].

Bár 1949-tôl már nem az MFT volt a kiadó, a Társulat fenntartotta magának a cserepéldányokkal való rendelkezést, tekintettel arra, hogy ,,a Földtani Közlöny egyetlen olyan szaklapunk, amelyért csereképpen biztosítani tudjuk hazai tudományunk részére a nélkülözhetetlenül szükséges [külföldi] szakirodalmat" [80: 223]. A csere szempontjából (is) hátrányos volt viszont, hogy nemcsak a korábbi gyakorlati kétnyelvúséget nem állították vissza, hanem a lapból úgyszólván teljesen eltûntek az idegen nyelvú közlemények. 1949-től, amikor a Közlöny újra nagyobb terjedelemben jelent meg, ennek már nyilvánvalóan nem terjedelmi korlátai, hanem szemléleti okai lehettek. Ezzel a Földtani Közlöny nemzetközi hatása minimálisra csökkent, amit az 1970-es évek óta alkalomszerúen megjelenő, a lap terjedelmének 510\%-át kitevő idegen nyelvú tartalmakkal már nem lehetett megváltoztatni. Érdemes ennek kapcsán visszautalni arra, hogy ScHMIDT Sándor másodtitkár már hét évtizeddel korábban, 1879-ben a kétnyelvúség bevezetése kapcsán elmondott előterjesztésében ,hangsúlyozta, hogy az izolált tudományosság milyen visszás állapot" [9: 196]. A Közlöny „,egynyelvúsítése” valószínúleg határozott tudománypolitikai célt követett, hiszen az 1952-es közgyúlésen ,a magyar földtani tudomány eredményeit a külföld felé is bemutatni kívánó" kiadványként az MTA az évtől kiadott Acta Geologica Academiae Scientiarium Hungaricae (1983-tól Acta Geologica Hungarica) címú orgánumát nevezték meg [82: 227-228]. Az MTA Müszaki Tudományok Osztályának Közleményei, mely 1951-től jelent meg magyar nyelven, a Földés Bányászati Tudományok Osztályának (X. osztály) különválásáig (1965) tartalmazott geológiai cikkeket. Utóda $A$ MTA Föld-és Bányászati Tudományok Osztályának Közleményei (1967-1971, 1971-1982 közt Geonómia és Bányászat) volt. Az idegen nyelvú kiadványok közt megemlítendő a Természettudományi Múzeum régóta megjelenő évkönyve (Annales Historico-Naturales Musei Nationalis Hungarici) és Fragmenta Mineralogica et Palaeontologica címú kiadványa (1969-től) és több egyetemi periodikum — a már létező szegedi Acta Mineralogica-Petrographica, és a miskolci, valamint (1954-től) a debreceni egyetem változó nevú kiadványai, az ELTE Annales Universitatis Scientiarum Budapestinensis de Rolando Eötvös Nominatae, Sectio Geologica címú lapja (1957-től). Ezek leginkább az adott intézményben dolgozó munkatársak idegen nyelvű tanulmányait közölték. A nagyobb lélegzetú tanulmányok és monográfiák ez időszakban is a MÁFI Geologica Hungarica kiadványsorozatának földtani és ôslénytani sorozataiban (Series Geologica, ill. Series Palaeontologica) jelentek meg.

Az 1951. VI. 6-i közgyúlésen a Közlöny szemrehányást 
kapott VADÁSZ Elemér elnöktől: „,több kiváló eredmény mellett is fennáll azonban még munkánkban a múlt említett hibáiból fakadó, sokszor egy helyen topogó szemlélődés. Ez mutatkozik meg Földtani Közlönyünkben is: Az élettel, a termelés fejlődésével, a haladó és élenjáró tudománnyal való kellő kapcsolat hiánya" [81: 342]. 1952-ben, csaknem negyedszázad után ismét közzétették a társulati tagnévsort [82: 326-327]. 1952. VI. 4-én az akkori elnök, SzÁDECZKYKARDOSS Elemér részletesen beszélt a geológiai kiadványokról. Megállapította, hogy „,a Földtani Közlöny eddigi terjedelme feladataink számára és munkatársaink számának és aktivitásának megnövekedése következtében kétségtelenül szúk lett”, és „feltétlenül szükséges a Földtani Közlöny terjedelmének fokozatos emelése, rovatainak átrendezése, újakkal kiegészítése, sôt egy a geológus-technikusaink és bányász-kartársaink fejlesztését biztosító külön ismeretterjesztő folyóirat megindítása is" [82: 227-228]. A Földtani Értesítő újraindítására vonatkozó, a közgyưlés által támogatott javaslat [82: 325] nem valósult meg.

A számos kisebb-nagyobb változás után 1952-ben a Földtani Közlöny külalakja elnyerte azt a formáját, amely csaknem húsz évig csak kevéssé módosult. Praktikus újítás volt, hogy 1954-től a füzeteket a fő bibliográfiai adatokat feltüntető gerincnyomással látták el (mely csak rövid ideig, az 1964. évi 4. füzettől az 1969. évi 4. füzetig szünetelt). Ez valószínúleg az Akadémiai Kiadóhoz való átkerülés egyik eredménye volt. A kiadó 1954-tôl egészen 1989-ig végre stabil hátteret nyújtott a lapnak, a sûrûn változó nyomdák helyébe ugyanekkor lépett az Akadémiai Nyomda. A megrendelő (a kiadói számlák kifizetője) azonban még 1987-ig a MTESZ volt. A kiadó- és nyomdaváltás hátterét az 1953. XII. 10-i társulati elnökségi ülés egy napirendi pontjának címe „A Közlöny Akadémiai kiadásának kérdése” [84: 180] és az 1954-es közgyúlési titkári beszámoló világítja meg. Eszerint ,,a MTESZ vezetőségével való tárgyalás során felmerült annak lehetôsége, hogy a Társulat a MTESZ kötelékéből kiválva, közvetlenül a MTA patronálása alá kerüljön, amelynek Földtani Főbizottsága eddig is szakmai felügyeletet gyakorolt a Társulat felett. Ezt megelőzóen már a Földtani Közlöny kiadása a Nehézipari Kiadótól az Akadémiai Kiadóhoz került.” [84: 291]. A kiválásra végül nem került sor.

1954-től nemcsak a kiadó és a nyomda (bő három és fél évtizedre), hanem a felelős szerkesztő személye is (több mint egy évtizedre) állandósult. 1967-ig VADÁsz Elemér határozta meg, mi (és mi nem) jelenhetett meg a Földtani Közlönyben (DuDICH et al. 1998: 29). Az 1955. évi (85.) kötetet egyébként éppen neki ajánlották 70. születésnapja alkalmából. FöLDVÁRI Aladár társelnök az 1954-es közgyúlésen a kor elvárásainak megfelelően a következőképp hasonlította össze a háború előtti és az akkori Közlönyt: „A Földtani Közlönyben a földtan minden ágából találunk dolgozatokat. Valamikor ez nem volt így. Egy-két specialistának mindig azonos témakörből vett írásai töltötték meg a Földtani Közlöny hasábjait. Ma viszont a kristálytantól kezdve ásványtani, kôzettani, földtani és ôslénytani dolgozatokat, tehát az egész földtan egyenletes fejlődésének spektrumát tükrözik vissza a Közlöny oldalai. Különösen örvendetes, hogy mindig új nevek tûnnek fel a dolgozatok szerzőiként, világos jeléül az ifjú gárda tudományos fejlődésének”. Ugyanő javasolta, hogy a Társulat múködésének súlypontja a szakülések helyett kerüljön át a Közlöny szakmai továbbképző szerepére, mert ,a jövőben a tagság zöme a fővárostól távoleső munkahelyeken, főleg ipari földtani szolgálatban lesz, és ezért a Társulat múködésében főként ezek érdekeit kell szem előtt tartani” [84: 281]. A nagy tervek végrehajtását persze akadályozták az olyasféle gondok, mint hogy 1953-ban ,,a szükséges papírkontingenst csak VADÁsz E. akadémikus közbenjárására sikerült biztosítani” [83: 291].

A rovatok lényegében a folyóirat hagyományos szerkezetét tükrözték: Értekezések, Rövid közlemények, Megemlékezések, (Könyv)ismertetések, Hírek, Társulati ügyek. Minden évben közölték a magyar földtani irodalom bibliográfiáját is. Az éves tartalomjegyzékekben „Bevezetés” címen szereplő új rovatba eleinte a politikai tartalmú ,vezércikkek” kerültek, később az elnöki megnyitók, foótitkári beszámolók, jubileumi köszöntések és egyéb társulati vonatkozású hosszabb közlemények, amelyek azóta is a „Társulati ügyek” rovattól elkülönülve találhatók a lapban. A néhány rövid életú rovat egy része a kort is jellemzi: az akadémiai határozat nyomán [82: 323] indított „Továbbképzés” (1953, 1954, 1956), a határok korlátozott megnyitása után az „Úti beszámolók” (1960-61). Az 1950-es években élte fénykorát az igen heterogén „Szemle” rovat, amelybe egyaránt bekerültek szakmai állásfoglalások, hírek, külföldi földtani intézmények, kutatások ismertetései, tudományelméleti fejtegetések, kutatás-módszertani, tudománytörténeti írások, emlékezések, a szaknyelvvel, egyes szakkifejezésekkel foglalkozó eszmefuttatások stb., mindezek tekintélyes részét VADÁsz Elemér írta. Az 1955-57 közti „Irodalom” rovat a hazai és külföldi szaklapok ,általánosabb érdekú" cikkeinek címét közölte. 1959-től kezdve a cikkeknél feltüntették, hogy tartalma melyik társulati rendezvényen hangzott el előadás formájában (ez a gyakorlat 1992-tôl szúnt meg), hiszen ez elvileg a Földtani Közlönyben való megjelenés egyik kritériuma volt.

A Földtani Közlöny formátuma változatlan maradt. Az illusztrációk száma már 1949-ben elérte a korábbi szintet, a külön fényképtáblák száma az 1950-60-as években 20-30 között mozgott, de néha meghaladta az 50-et, mivel a szöveg közt a papír gyenge minősége és az alkalmazott nyomdatechnika színvonala miatt lényegében csak vonalas ábrákat lehetett közölni (13. ábra). 1954-ben, több évtized után újra megjelent egy színes térképmelléklet. A példányszám — az MFT taglétszámát eleinte jócskán meghaladva — az 1950-es évek elejei 600 körülirôl 1954-ben 1000-re, 1955ben 1300-ra emelkedett, és 1969-ig 1200-1350 között váltakozott. Általában valamennyi füzet megjelent a tárgyévben, bár időrôl időre a negyedik füzet átcsúszott a következő évre. 1964-67 között a hosszabb cikkeknél általában feltüntették a kézirat lezárásának idejét.

Több mint félévszázados kihagyás után, 1961-ben kiadták a Földtani Közlöny regiszterkötetét az 1901-60 évekre (részletesebben 1. az Adattárban). 1962-ben újra megjelent a Társulat alapszabálya, melynek 3 . § 8. pontja szerint a Társulat „Biztosítja a MTESZ Vezetőségével együtt a társulati munka 


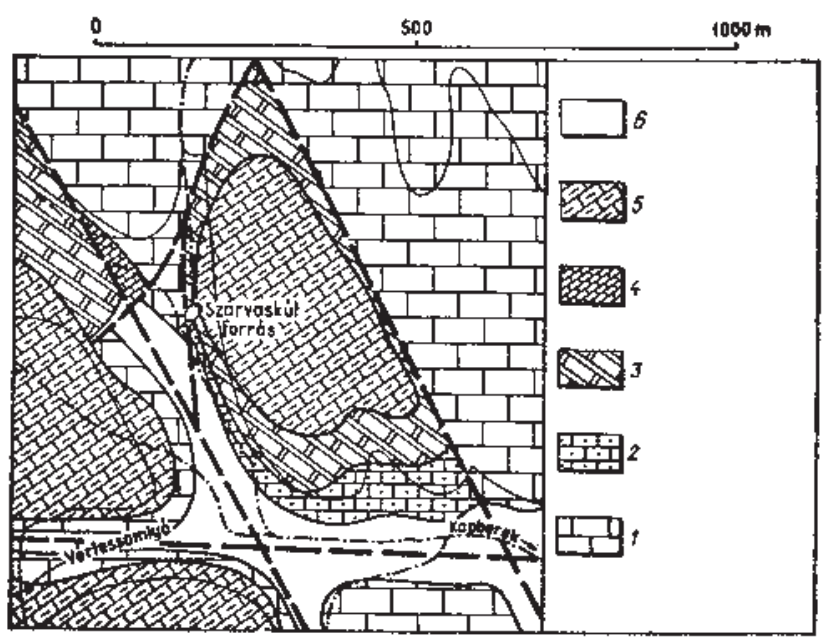

13. ábra. Vonalas ábra a Földtani Közlöny 90. évfolyamából (a Vértessomlótól K-re lévő Szarvaskút környékének földtani térképe, FüLöP József cikkéből) [90: 21, 3. ábra]

Figure 13. Linear figure from Vol. 90 of the Bulletin (geological map of Szarvaskut area to the east of Vértessomló, from the paper of József FüLÖP) [90: 21, figure 3.]

pénzügyi és technikai feltételeit, valamint a Földtani Közlöny és egyéb szakmai külön kiadványok megjelentetését." A 8. § kimondta, hogy ,a Társulat hivatalos lapja a Földtani Közlöny" [92: 366, 369]. (A továbbiakat 1. az Adattárban.) 1963ben a lapnak egy különszáma, az „Agyagásvány-füzet” is megjelent NEMECZ Ernő szerkesztésében, az MFT Agyagásványtani Szakcsoportja, a Szilikátipari Tudományos Egyesület és az Országos Magyar Bányászati és Kohászati Egyesület közös kiadványaként. Ez is jelezte, hogy az 1960-as évek elején megalakult tematikus szakosztályok tevékenysége nyomán a Földtani Közlöny által biztosított publikációs keret immáron szúknek bizonyult. Hamarosan meg is indultak, rendszertelenül, de többnyire évente egyszer, néhány száz példányban megjelenő, stencilezve, illetve késóbb rotaprint eljárással sokszorosított szakosztályi kiadványsorozatok, időrendben az Óslénytani Viták (1963-tól), a Mérnökgeológiai Szemle (1964-tôl), az Általános Földtani Szemle (1971-től) és a Földtani Tudománytörténeti Évkönyv (1972-tôl).

Az 1960-as évek második fele tartalmi és formai változásokat is hozott a Közlöny számára. Az 1964. 12. 16-i (!) közgyưlésen elhangzott főtitkári beszámoló szerint „1965re a Társulat saját kezelésébe veszi az eddig akadémiai kiadványként kezelt Földtani Közlöny szerkesztését”. Az ekkor bejelentett tagdíjelmelés kompenzációja gyanánt a KFH (Központi Földtani Hivatal) vezetôivel tárgyalásokat folytattak annak érdekében, „hogy az új formában, új tartalommal megjelenő Földtani Kutatás c. folyóiratot a jövőben minden társulati tagtársunk illetménykötetként, díjtalanul megkaphassa" [95: 363-364]. MeIsel Jánosné lett a technikai szerkesztő, e munkát 1983-ig végezte. Az MTA X. osztálya megszervezésével kapcsolatos munkálatok miatt szintén decemberre csúszott 1965-ös „évzáró közgyưlés" főtitkári beszámolója szerint a választmány a Földtani Közlönnyel kapcsolatban „konkrét és kiterjedt kifogásokat támasztott, főként a megjelenési formátum, a kihozatali minőség tekintetében", és munkabizottságot ho- zott létre, ,amely a Földtani Közlöny kiadását egészen a formátumig és a papírminőségig terjedően, esetleg más kiadó választásával, sürgős ügyként reformálni akarja" [96: 127]. A kiadóváltás elmaradt, mint ahogy az Akadémiai Kiadó is letett azon tervérôl, hogy változatlan terjedelemben ugyan, de csak két füzetben vállalja el a lap kiadását. A fontosabb változások 1967-tôl, a VADÁsz-korszak végével köszöntöttek be. Korábban a felelős szerkesztőt az alapszabály 8. §-a szerint az elnökség javaslatára a közgyúlés választotta meg [93: 369], az új alapszabály 8. §-a szerint viszont a felelős szerkesztő (a szerkesztőbizottság elnöke) a Társulat mindenkori elnöke lett. Így az 1967. évi 2. füzettel véget ért VADÁsz Elemér felelős szerkesztőségének négy év (1950-1954) megszakítással 1947 óta tartó korszaka.

\section{A Közlöny „csúcsidöszaka” (1967-1984)}

A tagszámrekorddal és a Földtani Közlöny, illetve a szakosztályi lapok legmagasabb példányszámaival fémjelzett korszak terjedelemcsökkenéssel és tagdíjemeléssel kezdődött. Az új felelős szerkesztô, NEMECz Ernő elnök az 1968-as közgyúlésen elmondta, hogy elkészült az új ügyrend, mely „biztosítja, hogy a szerkesztőségbe érkező cikkek kizárólag tartalmi alapon bíráltassanak el" (amivel vélhetőleg arra utalt, hogy korábban ez nem mindig volt így). Elhatározták, hogy a magyar szöveg rovására növelik az idegen nyelvú kivonat terjedelmét, hogy az „teljes képet adjon a külföldi olvasó számára”. A Földtani Intézet kiadványainak és a Földtani Kutatásnak a szerkesztőivel egyeztettek azon célból, hogy ,,a Földtani Közlöny bármely földtani munka (...) elvi alapkérdéseire irányuló kutatás eredményeinek publikációs helye" legyen. A beszámoló szerint elhatározták, hogy a Közlönyt jobb minőségú papírra nyomják, de a nyomdai árak eleve másfélszeresükre nőttek, így végső esetben a terjedelem csökkentése vagy a pénzügyi teher továbbhárítása is felmerült [98: 332]. 1969-70-ben a lap oldalszáma valóban 15-20\%-kal csökkent, és 1969-ben a tagdíjakat is emelték. A kéziratok 1969-től maximum 25 szabvány oldal (vagy két részletben megjelentetve 40 oldal) terjedelmúek lehettek (korábban egy nyomdai ív volt a korlát). A formai változások egyik első elemeként 1969-tôl a cikkek címlapján feltüntették a cikk bibliográfiai adatait (amelyek közt a Földtani Közlöny neve után már angolul szerepelt, hogy „Bull. of the Hungarian Geol. Soc.”). 1970ben a zöldes színú borítót kapott Közlönyön egy hatalmas 100-as szám hirdette a folyóirat eljövendô centenáriumát (és azt, hogy a római kötetszámozásról a címlapon is az arabra tértek át, 14. ábra). 1970-től a táblákat (15. ábra) és a szöveges részeket azonos — és a korábbinál jobb minőségú — papírra nyomták, így a szöveg közti fotók aránya is növekedett. Ez az állapot az 1980-as években is fennmaradt, bár a papír — és ezzel párhuzamosan a fotók — minősége újból romlani kezdett, különösen az ún. papírhiány (eufemisztikusan: „papírkontingens-problémák”) 1985-ben beköszöntött korszakában.

Az 1960-as évek közepétől az 1980-as évek elejéig tartó időszak az ankétok, kollokviumok, szimpóziumok virágko- 


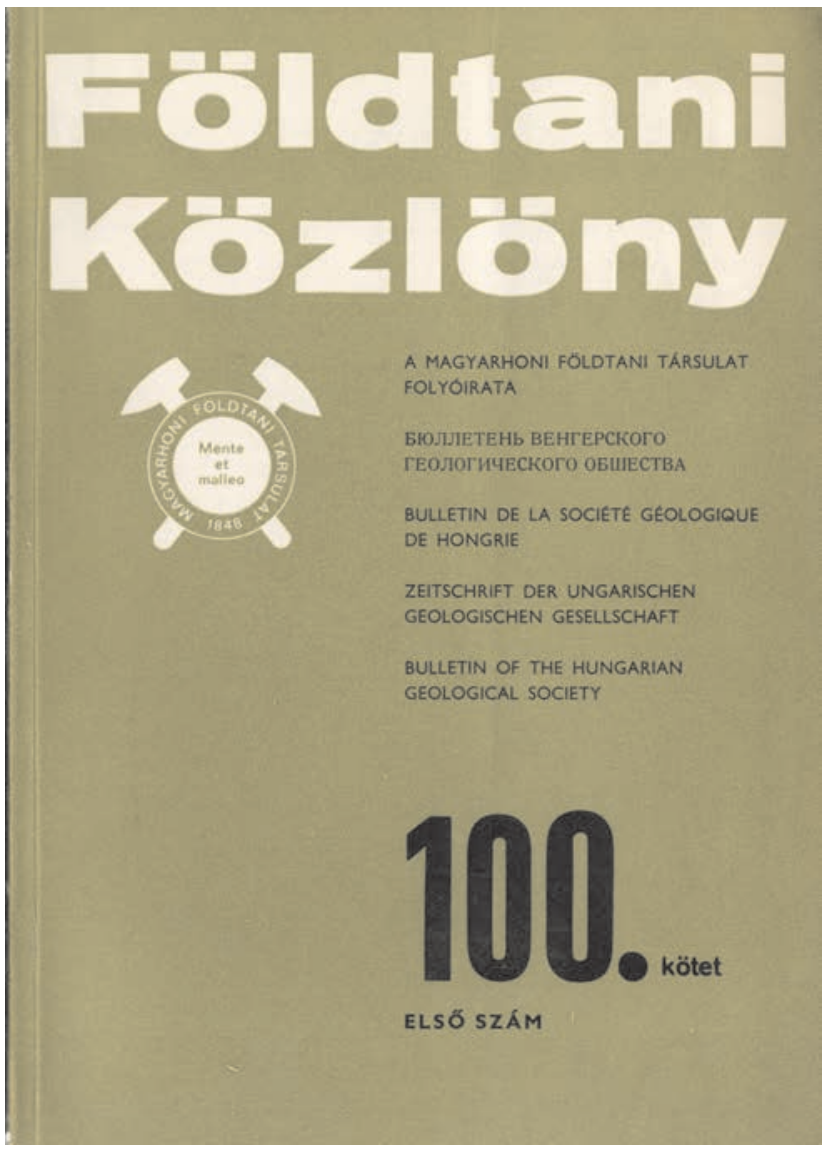

14. ábra. A Földtani Közlöny 100. kötete első számának borítólapja Figure 14. Front cover of the first issue of Vol. 100 of the Bulletin

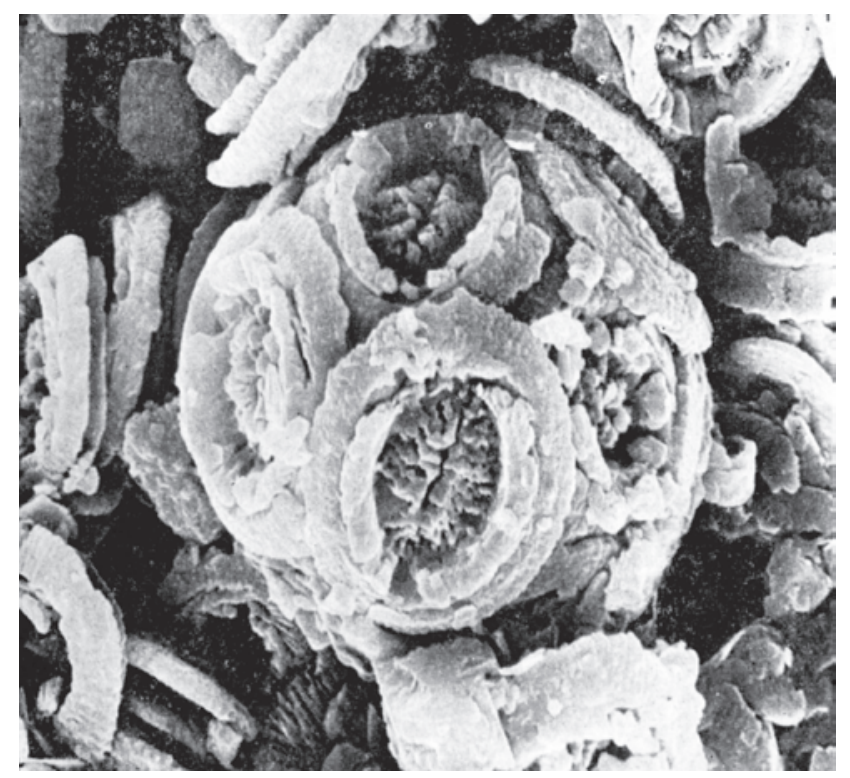

15. ábra. Fotó a Földtani Közlöny 107. kötetéből (Reticulofenestra lockeri kokkolit pásztázó elektronmikroszkópos képe BÁLDINÉ BEKE Mária cikkéből) [107: 87, IX. tábla, 1. ábra]

Figure 15. Photograph from Vol. 107 of the Bulletin (scanning electron microscope image of Reticulofenestra lockeri from the paper of Mária BÁLDINÉ BEKE) [107: 87, plate IX, figure 1] ra volt, ami a Földtani Közlönyben is tükröződött. Egyes füzetek (vagy összevont füzetek) kizárólag az adott rendezvény előadásait tartalmazták (a bibliográfiai adatokat l. az Adattárban). Így a Közlöny terjedelme kezdett olyannyira szúkösnek bizonyulni, hogy az 1973-as fótitkári jelentésben el is hangzott, miszerint ,az évi ötödik szám megjelentetése rendkívülien indokolt és időszerú lenne" [103: 98], ami csak alkalomszerúen valósult meg, egy-egy pótfüzet (supplementum) kiadásával 1975-ben és 1976-ban (utóbbi az OKGT támogatásával). A Közlöny tehermentesítésére a rotaprint kiadásban rendszeresen megjelenő szakosztályi lapok (Mérnökgeológiai Szemle, Óslénytani Viták, Általános Földtani Szemle, Földtani Tudománytörténet Évkönyv), illetve a különböző ankétek és továbbképzések hasonló kivitelû alkalmi kiadványai szolgáltak. 1974-ben fölmerült a Mérnökgeológiai Szemle társulati folyóiratként történő kiadása, illetve annak az igénye, hogy a fenti kiadványokat is egy közös szerkesztőbizottság vegye kézbe, ,,hogy az e téren kialakult bizonyos mértékig rendezetlen állapotokat szakszerűvé és jogszerúvé tegye" [104: 360]. A legtöbb szakosztályt rá egy évre is fel kellett szólítani, hogy ,,az alapszabály lazasága ellenére válasszanak vagy jelöljenek ki egy felelős szerkesztôt, mert az idevonatkozó törvényes rendelkezéseknek csak így tudunk eleget tenni” [105: 391].

1969-ben a szerkesztőbizottság újra megindította a „Válasz" rovatot, mely egyszeri reflexióra nyújtott lehetőséget a kérdéses cikk megjelenése után. Az 1970-es évek közepétől önálló rovatként jelent meg a „Tudománytörténet”, az évtized végétől pedig a „Vitafórum”. Az 1970-80-as évek külföldi expedíciós kutatásainak visszfényeként az 1980-as években néhány cikk erejéig élt „A külföld földtanából” rovat (ilyen jellegú cikkek inkább a Földtani Kutatásban jelentek meg). 1979-ben — tíz év után — a kiadványok árát, és ezzel a tagdíjat újból meg kellett emelni. Kuriózumként említhető, hogy ekkor vezették be az 1985-ös újbóli tagdíjemelésig „élő” legalacsonyabb, középiskolás tagsági díjkategóriát [109: 330]. Szintén az érdekességek közé tartozik, hogy a 110. kötetben az 1977. február 14-i Földtani Tudománytörténeti Nap teljes anyaga, 12 előadás angol nyelven jelent meg. 1981-ben kiadták a Közlöny újabb (immáron negyedik) regiszterkötetét (részletesebben 1. az Adattárban). Az 1981-es főtitkári beszámoló amellett, hogy a szakosztályi lapok fenntartásának szükségességét hangsúlyozta, ,felhívta a figyelmet ezek takarékosabb technikai szerkesztésére, terjedelmének behatárolására és tudatosabb kiadási politika szükségességére" [111: 404]. 1982-ben a MTESZ Sajtóbizottság segítségével megvizsgálták, „milyen kezdeményező lépéseket tehetünk a Földtani Közlöny terjedelmének bővítésére" (!) [112: 317]. 1983-ban MEISEL Jánosnétól VADÁSZ Elemér egy másik tanítványa és egykori munkatársa, KASZAP András vette át a technikai szerkesztői tisztséget.

\section{A papírhiánytól a pénzhiányig (1984-1989)}

Az 1970-es évek elejétől kezdve vált rendszerré, hogy a Földtani Közlöny 4. száma már jócskán átcsúszott a következő évre, noha a folyóirat impresszuma szerint a kéziratok 
többnyire már nyáron a kiadónál voltak. Nyilván nem azért, hogy a késést számszerúsíteni lehessen, de 1984-tôl az egyes cikkek alatt is olvasható a beérkezés dátuma. Az 1984es titkári jelentés hallgatóinak fülében már ismerősen csenghetett a bejelentés, miszerint a 114. évfolyam 4. füzetére ,ppapírkontingens problémák miatt kissé várni kell” [114: 418]. 1985-ben már arról kellett beszámolni, hogy „,sajnos az Akadémiai Nyomda késedelmes munkája kb. 1 éves elmaradást »eredményezett « a beszámolási idôszak végére." Viszont a „,szakosztályi kiadványok (...) időszakos megjelenése rendben levőnek minősíthető" volt [115: 339]. Abban az évben (16. ábra) elkerülhetetlenné vált az újabb tagdíjemelés. A direkt állami támogatás egészen az 1980-as évek közepéig biztosította a lap kiadásának pénzügyi fedezetét. Ez az anyagi biztonság az 1986. évi 3. számig [116/3] tartott. E füzet már közel egyéves csúszással, 1987 júliusában jelent meg, és ez volt az utolsó, melyet az Akadémiai Kiadó a MTESZ-nek számlázott, a közvetkező számtól a számlát már a Magyarhoni Földtani Társulat kapta és egyenlítette ki. Az 1986-os főtitkári jelentés ki is emelte,

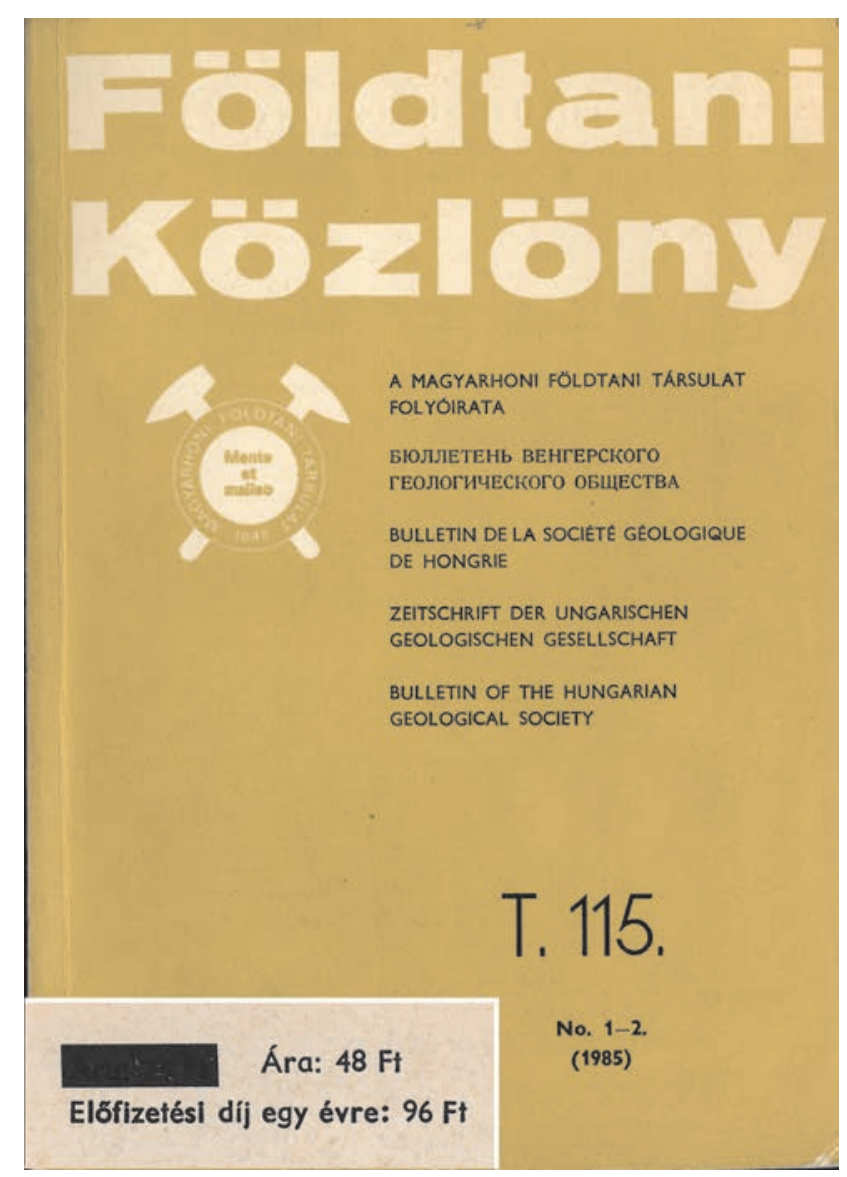

16. ábra. A Földtani Közlöny 115. évfolyamának egyik - a hátlap részletét mutató inzert alapján az az évi áremelés nyomán már 48 forintba kerülő összevont füzete, a 100. kötettől megszokott borítóval, mely az évek folyamán fokozatosan egyre sárgásabb árnyalatot öltött (vö. a 14. ábrával)

Figure 16. A double issue of Vol. 115 of the Bulletin (which, as shown by the inset of a detail of the back cover, was sold for 48 forints as a result of the rising of the price of the Bulletin in that year), with the front cover introduced from Vol. 100 that gradually became more yellowish over the years (cf. Figure 14) ,jól látszik, hogy a Közlöny állami támogatásának megszûnése billentette meg közel egyensúlyban lévő költségvetésünket. Feltúnő az aránytalanság a nyomdaköltségek és a kiadványokból befolyó bevételek között" [117: 342]. A 116. kötet 4. füzetében a borító harmadik oldalán feltúnt a „szerzőtársainkhoz” — a 120/3-4. számmal bezárólag — intézett közlemény, melynek 2. pontja szerint ,,a fokozódó papírhiány miatt és a hosszú átfutási idő lerövidítése érdekében" egy-egy kézirat hossza mindennel együtt legfeljebb 15 szabvány oldal lehetett.

A 117. évfolyamból már csak az első szám jelent meg a tárgyévben, azután pedig már éves, sôt több éves késések halmozódtak föl. Mindemellett az előállítási ár a korábbi 200250 eFt-ról 400 eFt-ra nőtt (118/3 füzet). „Korábban a papírkontingens, azután az idő változásával a költségoldal volt az a szorító tényező, amely miatt állandóan, mint Damoklész kardja, lebegett a fejünk fölött a szakosztályi lapok beszüntetésének, illetőleg a Földtani Közlöny oldalszámának redukálási veszélye" — foglalta össze a társulati szakmai folyóiratokat fenyegető körülményeket az 1988-as főtitkári jelentés [119: 346]. Az elnökség 1988-ban a szakosztályi „kőnyomatosak" megszüntetésével próbált az aktuális anyagi gondokon segíteni, ezt azonban a választmány nem támogatta (KÁzMÉr 2004). A Földtani Közlönynek az Akadémiai Kiadó által jegyzett utolsó, elvileg 1989. évi kötete [119] 1991-ben hagyta el a nyomdát füzetenként csaknem félmillió forintos áron. 1989-ben a Társulat a Földtani Közlöny esetében az évtized elején megszüntetett direkt állami támogatás visszaállításáért folyamodott [120: 2-3].

\section{Az elsố lépések ismét saját lábon (1990-2000)}

1989/90 az MFT és ezzel a Földtani Közlöny életében is rendszerváltást hozott. Megszúnt a szakmai egyesületek állami kontrollja, de az állam egyszersmind anyagilag kihátrált az olyan, korábban saját maga által létrehozott szervezetek mögül, mint a MTESZ. A Társulat így ismét kezébe vette folyóiratának kiadást, majd számos pénzügyi és technikai nehézséget legyúrve, 1991 után anyagilag elsôsorban a MOL Nyrt. támogatásának, emberileg pedig számos tagja erőfeszítésének köszönhetően, sikeresen fenntartotta azt. A nehézségeket jelentős mértékben anyagi tényezők okozták. Az állami fenntartás majdnem egyszerre szúnt meg vagy vált csak részlegessé és kiszámíthatatlanabbá a társulatot jogi tagdíjukon keresztül támogató bányavállalatok, az állami földtani kutatási és oktatási intézmények körében az élet más területein is lezajló gyökeres átalakulások és az ezt kíséró gazdasági válság és infláció közepette. Az állam, illetve a helyébe lépő magánvállalatok szemében a hazai nyersanyagkutatás elvesztette fontosságát, és ezzel a földtudományok hagyományos szerepe is leértékelődött, a környezetvédelem irányába történô, „átpozicionálódás” pedig egyelőre nem hozott látványos eredményeket a folyamat sokak számára kényszerú mivolta miatt sem. A Közlöny kiadása körüli állandósult mizériák okát talán jól megvilágítja az az egyszerú tény, hogy míg 1918-ban, tehát az I. 
világháború utolsó évében a Társulat 11000 korona közvetlen állami támogatást kapott, ami megegyezett a Közlöny az évi csaknem teljes kiadási költségével (11 344 korona) [48: 404 és 407], addig 1991 óta a közvetlen évi állami támogatás értéke gyakorlatilag 0 Ft.

Az 1986-1990-es időszakra vonatkozó főtitkári jelentés szóvá tette, hogy „az Akadémiai Kiadó most sem állt feladata magaslatán" és felvetette, hogy új kiadót és nyomdát kellene keresni [121: 16]. A választmány döntése nyomán a 120. évfolyamtól kezdve az 1989-es egyesülési törvény nyomán ismét önálló jogi személyként bejegyzett Társulat adta ki a lapot. A 120/1-2. összevont szám megjelenése után a főtitkári jelentés úgy ítélte meg, hogy a „kiadóváltás kétségtelenül gyorsított a megjelenésen, ugyanez a pozitívum nem mondható el a minôséggel és az árral kapcsolatban" [122: 303]. A Közlöny a következő, 120/3-4. számtól kezdve (17. ábra) sokáig a MOL Nyrt. — különböző névváltoztatásokon átesett, majd privatizált — szolnoki nyomdájában készült, ami az említett negatívumokat is orvosolta.

1990 volt az utolsó év, amikor a Társulat a Központi Földtani Hivatalnál (KFH) előfizette tagjai számára a Földtani Kutatás számonként 1000 példányát. A lap 1991-ben meg is szúnt, bár az 1989-es főtitkári jelentés még ajánlotta az egyéni előfizetést a tagságnak. 1990-től [120] emelkedett
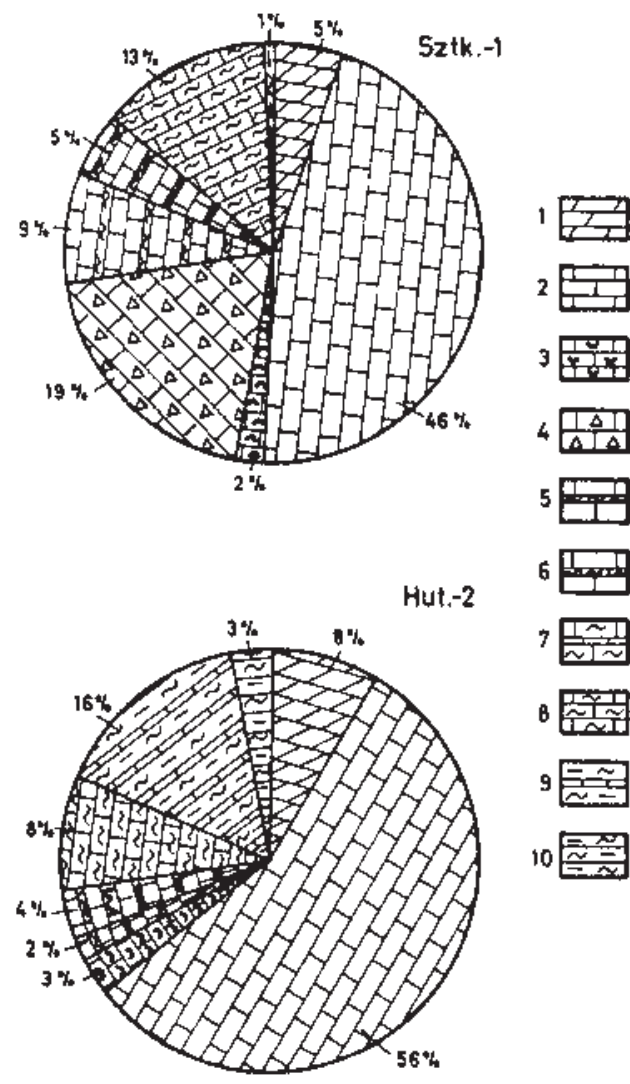

17. ábra. Vonalas ábra a Földtani Közlöny 120/3-4 számából (a ladini és a karni karbonátos rétegek kőzettípusainak aránya a Szentkatalin-1 és Husztót-2 fúrásokban, WÉBER Béla cikkéből) [120/3-4: 155, 2. ábra]

Figure 17. Linear figure from issue 120/3-4 of the Bulletin (proportions of rock types of the Ladinian and Carnian carbonate rocks in the Szentkatalin-1 és Husztót-2 boreholes, from the paper of Béla Wéber) [120/3-4: 155, figure 2] a Közlöny árát is tartalmazó tagdíj, a korábban ennek fejében a tagoknak (némely lapnál egyetemi tanszékekre is cserealapként) ingyenesen küldött szakosztályi lapokat pedig egységes 50 Ft-os előfizetési díj fejében kívánták elérhetővé tenni, évenként legfeljebb egy-egy számot kiadva, kivéve, ha a szakosztály külső támogatót szerez [120: 2-3]. Az 1990-es foótitkári jelentés úgy vélte, hogy e téren „,érdemi, érezhető változás csak 1991-ben várható. Ugyanakkor a következő tisztikarnak mindent el kell követni, hogy a gazdaságosság határain belül igyekezzenek a szakosztályi lapok nyomdai minőségén javítani” [1991: 17]. Öröm volt a sok ürömben, hogy 1990-ben sikerült állami céltámogatást szerezni a Közlöny kiadására [121: 18].

A Földtani Közlöny szerkesztőbizottsága legfontosabb feladatának azt tekintette, hogy legkésôbb 1994 elejéig, de inkább 1992 végéig szúnjön meg a Földtani Közlöny kétéves késése [122: 302-303]. Az 1991-es közgyúlés elhatározta, hogy megreformálja ,a nagy késésben levő (és emiatt sokak által elhanyagolt) Földtani Közlöny szerkesztését” (DUDICH et al. 1998: 77). KECSKEMÉTI Tibor elnök 1991 áprilisában megbízott egy alkalmi bizottságot a helyzet felmérésére. A „Szempontok a Földtani Közlöny korszerúsítéséhez” c. stratégiai anyag BREZSNYÁNSZKY Károly, BALLA Zoltán, KASZAP András, KÁZMÉr Miklós és VETô István javaslatai alapján májusra készült el. Fontos változást és egyben némi megtorpanást hozott a — KÁzMÉR Miklós által bevezetett — számítógépes szerkesztésre, tördelésre és digitális nyomdai kivitelezésre történő átállás. Ennek a szerzők egy része már vagy még nem tudott megfelelni, így e probléma áthidalása is a szerkesztőbizottságra és leginkább a szerkesztőkre hárult. Az új érát jelentő 1992. évi kötet első füzete [122/1] így is már 1992-ben, vagyis két évvel hamarabb jelent meg, mint az 1994-ben kijött, elvileg 1991. évi összevont szám [121]. Még egy fontos tényező járult hozzá az átalakulás nehézségeihez. A társadalmi rendszer megváltozásáig a Földtani Közlöny megjelentetésében sokan szívességből a szabad idejük, illetve — főnöki jóváhagyással vagy éppen ösztönzéssel — a munkaidejük alatt segédkeztek. Az egyre inkább rohanó élettempó következtében összezsugorodott a szabad idő, az új rendszerben a szívességi közremúködést kiszorította a piaci alapú, illetve egyre kevesebb helyen lehetett munkaidôben társadalmi tevékenységet végezni.

A szakosztályi lapok előfizetéses modellje nem bizonyult múködőképesnek. Az 1992-es főtitkári jelentés szerint „1993-tól csak akkor tudjuk a szakosztályi lapokat megjelentetni, ha szponzorokat találunk" [123: 309]. Ennek következtében az 1980-as évek közepén még évi több száz példányban megjelenő kiadványok 1992 óta sorban leálltak: 1992 óta szünetel a Földtani Tudománytörténeti Évkönyv (1972-1990, 13 szám) és a Mérnökgeológiai Szemle (19641992, 40 szám), 1993 óta az Óslénytani Viták (1963-1993, 39. szám, ebben egy összevont és egy különszám). Az „utolsó mohikán" 1995-ben az Általános Földtani Szemle (19711995, 27 szám) volt, amely később sajátos feltámadást ért meg a Hantken Kiadó (azaz KÁzMÉR Miklós) ,print on demand" alapú kiadásában (2004-2014, 28-31. szám). Az idézett foótitkári beszámoló szerint a Földtani Közlönyt „,csak a 
Magyar Földtanért Alapítvány pénzügyi lehetôségeihez mérten tudjuk megjelentetni". E kijelentés végül is egy pozitív fejleményt takart, ugyanis a MOL Nyrt. az említett, a Társulat által létrehozott alapítvány rendszeres támogatásával megteremtette a Földtani Közlöny anyagi hátterének biztonságát, és azóta is jelentôs szerepet játszik a Társulat fenntartásában. Az alapítványi befizetések elérték a 2,5, majd 1996-ra a 3,5 millió forintot [129: 154].

Az átalakulást a két világháború utáni pénzhiányos évekből már ismerős tünetek kísérték. A Földtani Közlöny korábbi 440-450 oldalas átlagos terjedelme az 1991-es mélyponton [121], amikor csak egy füzet jelent meg, 260 oldalra csökkent, 1990-ben [120] és 1992-ben [122] is csak két füzetet adtak ki. A megcsappant terjedelem s a szakosztályi kiadványok ellehetetlenülése miatt a publikálási lehetőségek beszúkültek. KECSKEMÉTI Tibor elnök ezért azt szorgalmazta, hogy a Közlönyben elsősorban az eredeti cikkek, tanulmányok jelenjenek meg, lehetôség szerint, a nemzetközi vérkeringésbe való intenzív bekapcsolódás érdekében, idegen nyelven. A társulati ügyeket, az irodalmat, az ismertetéseket az addigi havi helyett kéthavi megjelenésú, „feljavított” társulati programfüzetben tervezte megjelentetni, ehhez azonban nem sikerült elnyernie a választmány támogatását. Mindazonáltal a Közlönynek a tudományos cikkeken kívüli rovatai egy ideig szüneteltek, illetve összezsugorodtak. A borító külső és belső oldalai az 1990-es évek elején az átmeneti periódusokra korábban is jellemző váltakozást mutatták. Ennek leginkább szembeötlő epizódját 1992-ben a 122. kötet ,,piros számainak" anekdotába illő esete (18. ábra) jelentette annak előjátékaként, hogy a következő évben a teljes külső borító a korábbi borítócímlapok 1980-as évektől megszokott sárgás színét öltötte. A borító belsején az idők változását jelezte, hogy a magyar-oroszfrancia címeket rövid idoore (1990-91, [120-121]) háromnyelvú (magyar-angol-orosz) tartalomjegyzék váltotta fel, ugyancsak háromnyelvú kivonatokkal minden cikkhez, majd 1992től [122] a címlap és a borító szövegei, beleértve a tartalomjegyzéket, a magyar mellett már kizárólag angol nyelven íródtak csakúgy, mint a kivonatok. 1995-ben [125] a megalapítás óta létező - és általában rovat szerinti bontással közölt — éves tartalomjegyzék megszúnésével egy fontos segédeszköz tûnt el a folyóiratból. A példányszám a korábbi 2000-ről fokozatosan 1200-ra csökkent (részletesebben l. az Adattárban).

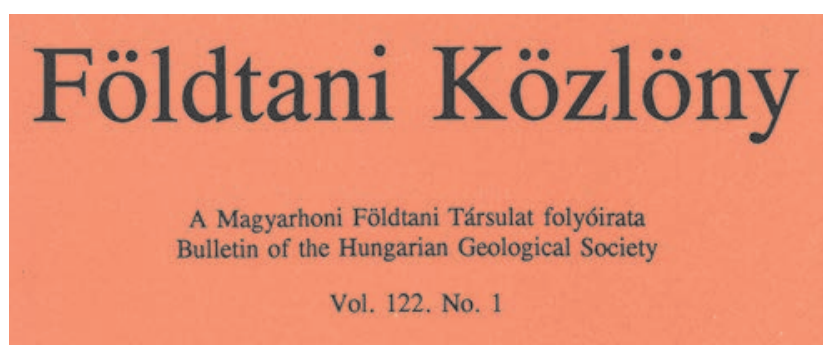

18. ábra. Részlet a Földtani Közlöny egyik hírhedt „piros számának” borítójából. Érdekesség, hogy e füzet [122/1] két évvel hamarabb került ki a nyomdából, mint az - elvileg - előzỏ évi 121. összevont kötet

Figure 18. Detail of the front cover of one of the notorious "red issues" of the Bulletin. Interestingly, this issue [122/1] came out of the press two years earlier than the (theoretically) precedent Vol. 121
A korábbi, 15 szabványoldalas méretkorlátozás utáni elsô új, a 122. kötet borítóin megjelent szerzői utasítás már úgy fogalmazott, hogy ,terjedelmi korlátot nem kívánunk szabni”. Így a folyóirat már a következő évben „kikerekedett", visszaállt az általában évi négy füzet. Az 1993-as (nota bene csak 1998-ban megjelent) főtitkári jelentés ,a még meglévő késés ellenére" jogos büszkeséggel állapította meg, hogy a Társulat „olyan mennyiségben és minőségben (természetesen külsô támogatásokkal) jelentethetett meg folyóiratot, szakosztályi lapot, egyéb kiadványokat, mellyel bármelyik hazai intézménnyel felvenné a versenyt" [118: 719]. A terjedelem 1993-tól [123] tartósan 500, majd 600, alkalmanként 700 oldal fölé nőtt, vagyis elérte az 1980-as évek szintjét. Ezt részben az is okozhatta, hogy a szakosztályi lapok megjelentetésére nem volt lehetőség, az oda szánt cikkeket, tanulmányok egy részét is a Közlönyben közölték, amit különben a fótitkár is ajánlott [119: 137]. A cikkek számát szaporíthatta az is, hogy a fentebb említett szerzői utasításból kimaradt az a korábbi megszorító kitétel is, mely szerint ,„a Földtani Közlönyben csak olyan cikket közlünk, amelyet megelőzőleg a Társulat fórumán előadtak és megvitattak. Ezt a címhez tartozó lábjegyzetben minden esetben fel kell tüntetni”. E látszólagos aprósággal egy igen hosszú gyakorlat ért véget, ami tükrözte mind a Társulaton belül szakmai élet jellegének változását, mind a Társulaton kívüli szakemberek irányába történő nyitás igényét és annak szükségességét, hogy a Közlöny továbbra is általános geológiai publikációs fórum legyen.

Ezen időszakban már ismét rendszeresen, de kis számban és terjedelemben jelentek meg idegen nyelvú közlemények a Közlönyben. A hasonló profilú, idegen nyelvú lapok (1. IV.1.) közül a Fragmenta Mineralogica et Palaeontologica 1996-ban jelent meg e formájában utoljára, de 2000-től Fragmenta Palaeontologica Hungarica névvel, címének megfelelően szúkített profillal ismét megjelenik. A Földtani Intézet Geologica Hungarica, Series Geologica és Paleontologica c. sorozataiból mindössze 1-1 kötet jelent meg 1990 és 2000 között. Az Intézet magyar nyelvú kiadványai közül az Évkönyvet 1991-ben adták ki utoljára, az Évi Jelentések komoly késésekkel ugyan, de megjelentek.

A csúszások fokozatosan rövidültek, és 1998-ra ,a Földtani Közlöny utolérte magát, felszámolta hosszan elhúzódott lemaradását" (DuDich et al. 1998: 86). Ez eleinte nem vonatkozott a társulati ügyek rovatra, hiszen az 1998-as kötetben még mindig csak az 1994-95-ös társulati ülések listáját lehetett olvasni, e téren a lemaradást csak a 2000-es évek elejére sikerült behozni. Ezen időszakban a külön címmel jelölt vagy jelöletlen hagyományos „rovatok” (közgyúlési elnöki megnyitó beszédek és főtitkári jelentések; értekezések; rövid közlemények; megemlékezések; hírek és ismertetések; társulati ügyek) közül a „Hírek, ismertetések” helyett 1992-94 között csak a könyvismertetések kaptak nyomdafestéket „Könyvkritika” rovatcímmel. A korábbi „Szemle” rovattal párhuzamosítható „Tájékozódás” csak a 1993. évi [123] kötetben szerepelt. A „Vitafórum” a Földtani Közlöny megjelenésének notórius késései miatt 1990-től sok évig szünetelt, később „Fórum”, illetve „Vita” címen jelentkezett 
alkalomszerúen. A magyar földtani irodalom repertóriuma utoljára a 2000. évi [130] kötetben jelent meg (e sokak által hiányolt összeállításról 1. JÁMBOR 2006 kitűnő elemzését). Megritkultak, jóformán eltúntek a tematikus füzetek és különszámok (1. az Adattárat).

Mivel az MFT a korszak elején nem engedhette meg magának, hogy folyóiratához megfelelő minőségú papírt vásároljon, a 119-124. kötetekben visszatért a külön fotótáblák korszaka. Az 1995-ös [125] újabb tagdíjemelés évétől viszont már teljes terjedelmében múnyomó papíron készül a Földtani Közlöny, mely azóta is kifogástalan minőségben közli az újabban nem ritkán színes fotókat is (19. ábra).

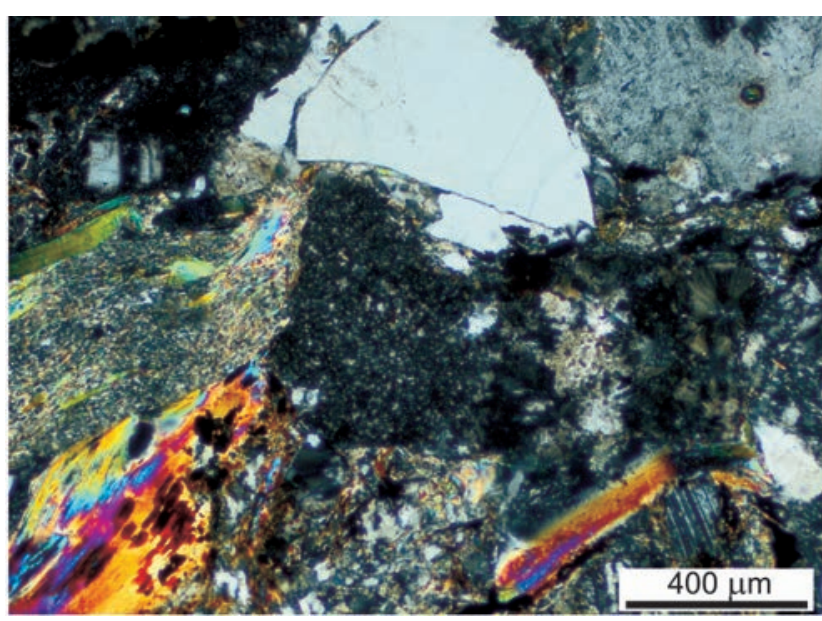

19. ábra. Vékonycsiszolati felvétel a Földtani Közlöny 145. évfolyamából (metamorf kőzettörmelék és vulkanitszemcsék homokkőben, +N, HIDASI T. et al. cikkéből) [145: 15, 9. ábra f)

Figure 19. Microphoto of a thin section from Vol. 145 of the Bulletin (metamorphic rock fragment and volcanic lithic grains in a sandstone sample, $+N$, from the paper of HIDASI, T. et al.) [145: 15, figure 9f)

Az átalakulás korábban említett nehézségeit a szerkesztés körüli problémák is tarkították. A KASZAP Andrást a 122. évfolyamtól felváltó, és a korábbi technikai szerkesztőkhöz képest jóval önállóbban — és öntörvényúbben — tevékenykedő KÁZMÉr Miklós helyére ismét KASZAP András tért vissza a 125-126. kötet erejéig, de ez nyilvánvalóan csak ideiglenes megoldást jelentett, és 1997-ben [127] bevezették a mai napig követetett mechanizmust. Akkortól az MFT elnöke helyett, aki addig nemcsak felelős kiadó, de felelős szerkesztő is volt, egy az elnökség által felkért főszerkesztô áll a lap élén (1. az Adattárat). Az első főszerkesztő a stabilitást hozó, hosszú ideig múködő CsÁszÁR Géza volt, akinek az erőfeszítései nagyban hozzájárultak ahhoz, hogy a Földtani Közlöny megmaradjon a szakma fontos folyóiratának. 1997 eseményei közt még megemlítendő, hogy újraindult a Földtani Kutatás, de mivel a Magyar Geológiai Szolgálatnak (MGSZ) nem volt rá költségvetése, megfelelő mennyiségû előfizetôt pedig nem sikerült gyújteni, a kiadvány $\mathrm{CD}$ formájában tudott csak megjelenni, majd az internetre vándorolt, és az MGSZ-nek a Magyar Bányászati Hivatalba 2007. január 1-jével történt beolvasztásával ismét csak megszúnt.

A Közlöny folyamatos megjelenését a tagság, egyes ta- gok célzott támogatása, a MOL Nyrt. és a Magyar Állami Földtani Intézet szervezeti tagsági díja tette lehetôvé. Az évezred végén azonban ismét jelentkeztek a pénzügyi problémák. A társulati Ellenőrzô Bizottság 1999-ben a tagdíj emelését és a Földtani Közlöny ,szétosztási rendjének” módosítását, illetve árának emelését javasolta [130: 191]. A közölt cikkek számának csökkenését elkerülendő korlátozni kellett a tanulmányok terjedelmét. 2000-ben az elnökség a Gazdasági Bizottság javaslatára úgy határozott, hogy 150 oldalban maximálja egy füzet terjedelmét, és a 131. kötet két összevont füzetben jelenjen meg. Az igazán nagy horderejú változást azonban az a bejelentés rejtette magában, hogy a gazdasági helyzetünk javítása érdekében a Gazdasági Bizottság a „kétfokozatú tagdíj” — vagyis külön előfizetési díj — bevezetését javasolta. Az előfizetési igényeket kérdőívvel mérték fel [131: 328].

\section{A külön elófizetési díjtól az ingyenes online elérésig — gyökeres változások az új ezredévben} (2001-2019)

Az új ezredév lényeges átalakulásokat hozott a Földtani Közlöny státusában. Azzal a 2000. 09. 5-i elnökségi határozattal, mely kimondta, hogy a folyóiratot a továbbiakban csak az kaphatja meg, aki vállalja annak költségét, véget ért a 130 éves hagyomány, mely szerint a Közlöny a társulat teljes jogú tagjainak a tagdíj vagy névleges előfizetési díj ellenében jár. A körülmények kényszerítő ereje tehát eltávolította a Társulat legfontosabb szellemi termékét saját tagjainak egy jó részétől, ami a későbbi olvasottságra is kihatott. A Társulat azon erôfeszítése viszont, hogy a Közlönyt digitális formában elérhetővé tegye a világhálón, beleértve a korábbi számokat is, a 2010-es évek végére nemcsak visszaállította a tagok és a Közlöny szoros kapcsolatát, hanem korábban elképzelhetetlen mértékben kitágította a folyóirat hatókörét azzal, hogy 2017 óta bárki ingyenesen elérheti a Közlöny régi és legújabb számait is a Föld bármely (internetkapcsolattal rendelkező) pontjáról. Mindazonáltal a digitális világ illékony virtuális varázslatainak óvatosabb csodálói, mint jelen tanulmány szerzője is, a nyomtatott példányszámok zsugorodó számai láttán aggodalommal tehetik fel a kérdést: meddig él még a Közlöny kézzel fogható, könyvtári polcra tehető és ott bármikor, bármilyen technológiai változás után is elérhetô és olvasható füzetek formájában is.

2001-tôl tehát a Közlöny többé már nem járt a tagdíj fejében. Az első években az előfizetők száma 480-500 körül mozgott, tehát a tagság mintegy felét tette ki, így a lap példányszáma is közel felére, 600-650 példányra csökkent (1. az Adattárat is). A 2001-es főtitkári jelentés is már felvetette, hogy ,a kis példányszám egyébként veszélyeztetheti a folyóirat sorsát is" [131: 178]. Említésre méltó, hogy magát a 2001. évi kötetet [131] jelentős részben egy társulati tag, DoBos Irma támogatásából jelentette meg az MFT. Az elnökség a választmány támogatásával bizonyos terjedelmi korlátozásokat is életbe léptetett a Közlöny folyamatos megjelentetése, egyben a szakmai színvonal biztosítása érdeké- 
Földtani Közlön $132 / 1$ A Magyarhoni Földtani Társulat folyóirata BULLETIN OF THE HUNGARIAN GEOLOGICAL SOCIETY

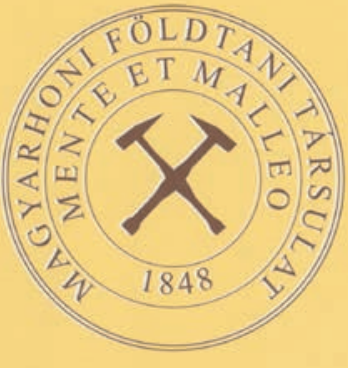

Budapest, 2002

20. ábra. A Földtani Közlöny Simonyi Dezső által tervezett, 2001-2007 [131137] közt használt boritójának címlapja [132/1: B1]

Figure 20. Front cover of the Bulletin, designed by Dezsö SIMONYI, in use between 2001-2007 [131-137][132/1:B1]

ben [131: 311]. A 131. évfolyamtól a Közlöny — SiMONYI Dezsố által tervezett — új borítóval jelent meg, mely megórizte a sárga színt, de sokkal vonzóbb külsốt adott a füzeteknek (20. ábra). A formátum maradt B5-ös, bár már 2000-ben felmerült a nagyobb formátumra való áttérés gondolata, amit anyagi okok miatt elvetettek [130: 328]. A folyóirat a 2003-tól, a részben anyagi okokból, de leginkább az elektronikus előkészítésnek az ábrákra történő kiterjesztését is lehetôvé tévő nyomdaváltás után immáron teljesen digitalizált formában készültt. Addigra sikerült a megjelenés lemaradását annyira ledolgozni, hogy a márciusi közgyúlésen a tagok már kézhez kapták a legfrissebb lapszámot [133: 168]. 2004-ben a Magyar Tudományos-, Üzemi és Szaklapok Újságíróinak Egyesülete a Földtani Közlönyt színvonalas tartalma és kivitele alapján dicséretben részesítette [134: 479].

A lap szerkezetét tekintve újdonság volt, hogy 20052007 között [135-137] külön rovatként jelentek meg „Tanulmányok Erdély földtanából”. 2014-ben [144] indult a „Földtan a gyakorlatban” rovat, mely bizonyos mértékig az 1956-tól az Országos Földtani Főigazgatóság, majd a Központi Földtani Hivatal, illetve annak jogutódai által kiadott
Földtani Kutatás megszúnése után maradt úr egy részét hivatott betölteni. 2001-tôl [131] egy-két alkalommal jelentkezett a „Földtani megfigyelések — amit újra már senki sem láthat" rovat az építkezések idôszakos feltárásaiban rögzített megfigyeléseket tartalmazó rövid közleményekkel. Némileg hasonló jellegú közlemények jelentek meg 2003-2004ben [133-134] „Építók figyelmébe” rovatcímmel. 2018-tól [148] „Élvonalban” megjelölés található egyes szakterületek legújabb fejleményeit ismertető cikkek fölött. 26 év után, 2002-ben [132], a kvarter-ankét alkalmából minisztériumi és OTKA-támogatásból jelent meg újra egy különszám. Több tematikus és jubileumi szám is volt, ezek közül a Horváth Ferenc-emlékszám - pályázati előírások miatt — sajátos módon két külön füzetben jelent meg [149/3 és 4]. (L. az Adattárat is.) Ezen időszak szülötte volt az első csak online elérhető - virtuális szakosztályi folyóirat, „stílszerúen" a Geomatematikai Szakosztály Journal of Hungarian Geomathematics címú lapja (3 szám, 2003, 2004, 2007).

A Közlöny formátuma 2008-ban, 130 év után drasztikusan megváltozott. 1878 óta, bár a „,békebeli” (I. világháború előtti) méretükhöz képest a füzetek látszólag fokozatosan egyre kisebbek lettek, valójában nem történt lényeges változás a folyóirat formátumában, ugyanis csak a papírméret csökkent, a tükörméret nem, sőt még valamelyest nôtt is, mígnem elérte a B5 méret felső határát. 2008-ban viszont a nagyalakú, A4 formátumra való áttéréssel még az 1878-asnál is nagyobb mértékú változás történt. Emiatt a beköszöntốk, a cikk-kivonatok és az irodalomjegyzékek kivételével immár az egész folyóirat kéthasábos tördelésú lett, korábban (1970 [100] óta) csak a „kisbetús rovatokat” (Hírek, ismertetések; Társulati ügyek) szedték így. A 600 oldal körüli terjedelem ennek megfelelően 400 körülire csökkent. Az igényes tipográfiájú és grafikai hátterú — ismét SIMONYI Dezső által tervezett — új borítón (21. ábra) számonként változó színes képek is vannak valamelyik cikkből, hiszen ez időre a színes ábrák száma is jelentősen megnőtt. A külön nyomtatott éves tartalomjegyzék továbbra sem tért vissza, és 1981 óta nem jelent meg új regiszterkötet sem, de az összes évfolyam számonkénti tartalomjegyzéke az OSZK Elektronikus Periodika Archivum és Adatbázis (EPA) oldalain és a magyar folyóiratok tartalomjegyzékeinek kereshetô adatbázisában (MATARKA) elérhetô.

A Földtani Közlöny az új évezredben az anyagi problémákon túlmenően új kihívásokkal is szembekerült. A magyar földtudománynak az immáron az angol nyelv által uralt nemzetközi tudományos világgal folytatott, adminisztratív megkötésektől mentes szabad érintkezése nyomán többször felvetődött a folyóirat (túlnyomóan) magyar nyelvú mivoltának megszüntetése, vagyis a folyóirat angol nyelvúvé tétele [pl. 132: 178]. Erre számos példa van a környező országokban, pl. Horvátországban (1992-től), Csehországban (1993tól), Ausztriában (2004-től) vagy Lengyelországban angol, Szerbiában pedig kétnyelvú (szerb és angol) a társulati folyóirat. Hogy ez mégsem történt meg, annak legfontosabb oka az, hogy a Földtani Közlöny meghatározó és nem nélkülözhetô szerepet tölt be a magyar földtani szaknyelv fenn- 


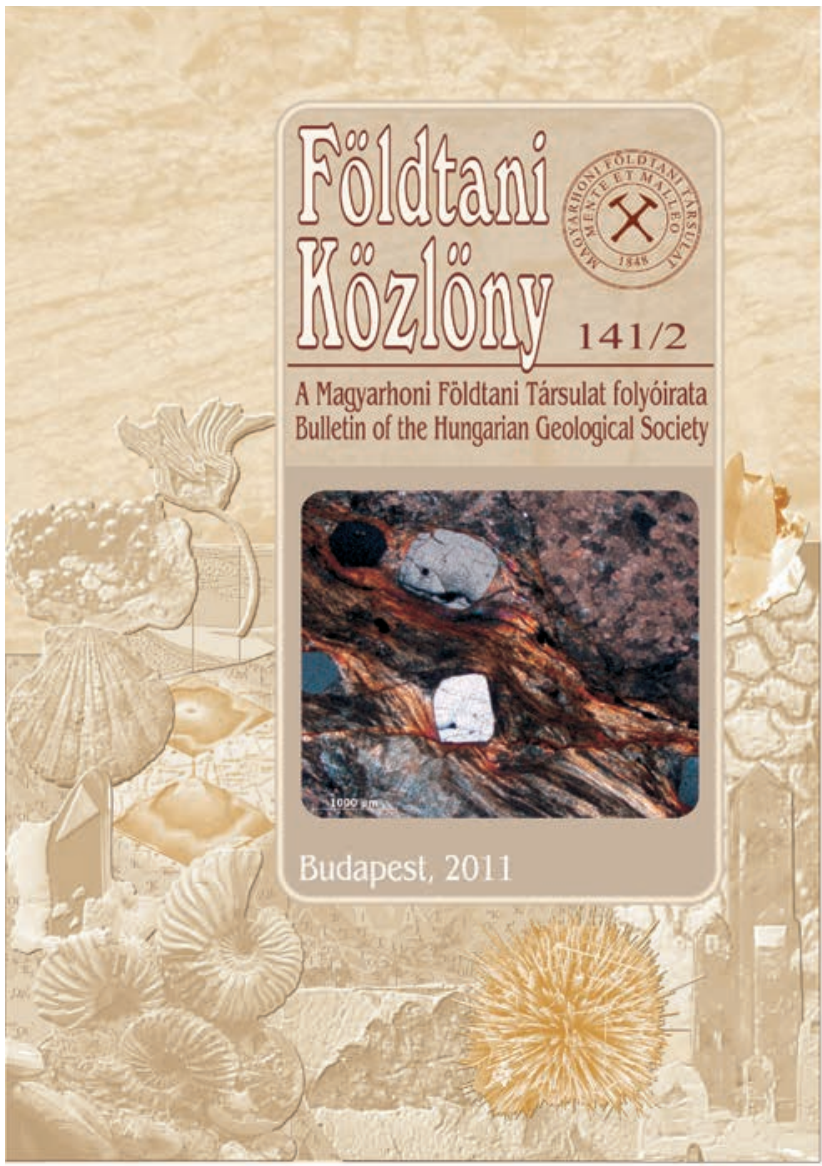

21. ábra. A Földtani Közlöny SimONYI Dezső által tervezett jelenlegi, 2008 [138] óta használt borítójának címlapja [141/2: B1]

Figure 21. Present front cover of the Bulletin, designed by Dezsö SIMonYI, in use since 2008 [138] [141/2: B1]

tartásában és fejlesztésében. A magyarnyelvúség nyilvánvalóan nem segíti a folyóirat nemzetközi elismertségét, ami a szcientometriai alapú pályázati értékelések és tudományos minősítések korában sokak számára nem teszi elég „,vonzóvá" a lapot. Ezt valamennyire ellensúlyozandó, egyrészt megnövelték a cikkek angol nyelvú kivonatának terjedelmét, és lépések történtek arra, hogy a Közlönyt a nagy nemzetközi tudományos adatbázisok is számon tartsák. PIROs Olga erőfeszítései nyomán 2009-től sikerült megvalósítani a Scopus adatbázisban történő referálást. A saját honlapra költözéssel együtt 2017-től a cikkek digitálisobjektum-azonosítóval (DOI) ellátva jelennek meg, ezzel a Crossref adatbázisban is megjelennek [147: 129]. A DOI további elónye, hogy az azonosító egy kattintással az adott tanulmány eredeti fogadó oldalára (landing page) viszi olvasót, és ott a cikk a megjelenéssel egyidejúen nyílt hozzáféréssel elérhetô.

Itt említhetô meg, hogy a hazai idegen nyelvú szakfolyóiratok közül az Acta Geologica Hungarica a nemzetköziség felé való nyitás jeleként 2007-től Central European Geology néven folytatja múködését, de továbbra is uralkodóan magyar szerző́k cikkeit közli. A szintén hazai beágyazottságú egyetemi kiadványok közül megszűnt az ELTE Annales Universitatis Scientiarum de Rolando Eötvös Nominatae.
Sectio Geologica (2004-ben), a szegedi Acta MineralogicaPetrographica pedig 2008 óta csak kivonatköteteket (Abstract Series) jelentet meg. A Földtani Intézet Geologica Hungarica, Series Geologica és Paleontologica c. sorozatainak kötetei több éves kihagyásokkal, de meg-megjelentek. Az Intézet magyar nyelvú kiadványai közül az Évkönyvet 1991-ben adták ki utoljára, az Évi Jelentések komoly késésekkel ugyan, de szintén megjelentek.

Az elő́bbiekkel részben összefüggő kihívást jelentett a világháló digitális univerzumába való bekerülés, ami nyilvánvalóan létkérdés volt a Közlöny számára. Ehhez képest a folyamat igencsak késôn indult és vontatottan haladt, valószínúleg nem is annyira szemléleti, mint inkább a „szokásos” anyagi okokból. Már 2001-ben „megkezdődött egy olyan technikai korszerúsítési folyamat, amelynek egyik eredménye lehet előbb a tartalomjegyzéknek, majd a teljes füzeteknek az internetre tétele is" [132: 778], de ez sajnos elég hosszúra nyúlt. 2003-tól [133] az MFT honlapján az egyes füzetek megjelenésével egy idóben a magyar és az angol nyelvú összefoglalást is közzétették [133: 82]. A formátumváltással egy időben, 2008-ban kísérleti jelleggel online elérhetôvé tették a Közlöny az évi számait [138], és 2009-re [139] tervezték a csak az előfizető́k számára elérhetô online elérés bevezetését [138: 126], ami azonban csak 2013-tól [143] valósult meg [145: 115]. 2015-tól [145] a társulati tagok online ingyenesen elérhették a Közlöny számait, így a lap virtuálisan visszanyerte tagilletményi szerepét. CSERNY Tibor kezdeményezésére és irányítására, BAKSA Csaba elnök támogatásával megkezdődött és lényegében befejeződött a retrospektív digitalizálás is, mely PIROs Olga és NÉMETH Norbert közremúködésével zajlott, intézményi támogatást nyújtott az Országos Széchényi Könyvtár (OSZK), a Magyar Bányászati és Földtani Hivatal (MBFH) és a Magyar Földtani és Geofizikai Intézet (MFGI), illetve együttmúködési megállapodás született a Biodiversity Heritage Libraryvel is (22. ábra A). A Közlöny mellett digitalizálták az MFT szakosztályainak sokszorosított kiadványait (Általános Földtani Szemle, Földtani Tudománytörténeti Évkönyv, Mérnökgeológiai Szemle, Őslénytani Viták) és az MFT-hez csak tematikailag kötődő Földtani Kutatás is bekerült az OSZK Elektronikus Periodika Adatbázisába (EPA, (22. ábra B).) [145: 115, 146: 96, 147: 129, 148: 116].

Hosszas belső polémia után az MFT elnöksége úgy döntött, hogy 2017-től a Földtani Közlöny számai már megjelenésükkor nyílt hozzáférésúek legyenek, ami a korábbi számok online elérésének biztosításával új fejezetett nyitott a folyóirat történetében. Ezt tükrözi a rövid idő alatt elért több tízezres látogatói szám is. Visszafele haladva egyre több évfolyam tartalma érhetố el a folyóirat saját honlapján a www.foldtanikozlony.hu-n. A folyóirat szerkesztése és online közzététele szintén 2017 óta az MTA Könyvtára szerverén, az MTAK által fenntartott webes felületen történik, mely az Open Journal Systems (a tudományos folyóiratok online közzétételének és kezelésének nyílt forráskódú megoldását szolgáló) platformon alapul. A folyóirat új, saját honlapot is kapott [147: 129, 148: 116, 149: 8]. A megállapodás és az áttérés elsősorban BAKSA Csaba, SzTANÓ Orsolya 


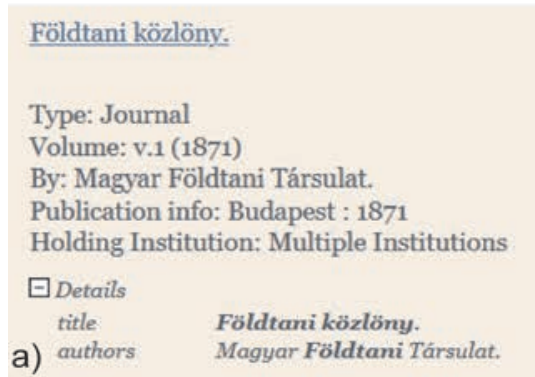

22. ábra. a) A Földtani Közlöny adatlapja a Biodiversity Heritage Library honlapjáról (a Társulat 1950-1962 közt hivatalos nevével). b) A Földtani Közlöny oldala az Országos Széchényi Könyvtár Elektronikus Periodika Adatbázisában (részlet)

Figure 22. a) Data sheet of the Bulletin from the website of the Biodiversity Heritage Library (with the outdated official name of the Society, used from 1950 to 1962). b) Web page of the Bulletin in the National Széchényi Library, Electronic Periodicals Archive \& Database (detail)

és BARTHA István (online technikai szerkesztő) tevékenységének gyümölcse volt.

A fentebb ismertetett változások természetesen további drasztikus visszaeséseket okoztak a nyomtatott változat elôfizetési számaiban és így a példányszámokban is. Az előfizetési díj bevezetése utáni 450-500 előfizető a fizetős online elérés megjelenésekor kerekítve 250-re (ebből 90 céges, illetve intézményi), az ingyenes online elérés után 2018-2019ben kerekítve 175-re (ebból 90 céges, illetve intézményi), az 560-650-es példányszám pedig 350-ra, majd 270-re csökkent (további részletek az Adattárban). A digitális irodalmazás kényelme és többletszolgáltatásai miatt a nyomtatott formátum napjai valószínúleg meg vannak már számlálva.

A Közlöny költségei a társulati gazdasági bizottság jelentései alapján 2007-2012 között a postázással együtt évi 3-3,5 millió, a fizetôs online elérhetôség korszakában (2013-2014) 2,8-3,5 millió, a tagdíj ellenében biztosított és az ingyenes on-line elérhetôség éveiben (2015-2016, ill. 2017-2018 [utolsó adat]) 2,3-2,7 millió Ft-ra rúgtak. Mivel az előfizetési díjak e költségeknek csak egy részét fedezik (2016-ban 42\%-ot [2017: 124]), a megjelenés csak a MOL Nyrt-nek köszönhető külső támogatás révén, illetve további szponzori (MFGI) és pályázati források (NKA, MTA) bevonásával volt lehetséges, és a jövőben ez még inkább így lesz.

Visszautalva e rész bevezetôjére, bizonyos, hogy az előfizetett példányszám csökkenése, ezáltal a fajlagos költségek növekedése alkotta ördögi kör miatt a jövőben még nagyobb viták lesznek a nyomtatott formában történő megjelenés körül, ami felidézi NEMECz Ernő társulati elnöknek a fo- lyóirat 100. évfolyamában megjelent, előrelátó gondolatait: „Napjainkban a tudományos információközlés forradalma bontakozik ki: filmek, mágneses szalagok, ferrit-kristályok és ki tudja milyen embercsinálta eszközök fogják ellátni az ismeretek rögzítését, válogatását és továbbítását. Lesz-e szükség még hagyományos folyóiratra? . . Minden bizonynyal még sokáig megmarad a tudományos eredmény ismertté tételének jelenlegi módja és Közlönyünk még sok évjáratot fog megérni. De bizonyos az is, hogy állandóan módosulva-alkalmazkodva a kor és tudomány követelményeihez" (NEMECZ 1970).

\section{Köszönetnyilvánítás}

A cikkbe a Magyarhoni Földtani Társulat korábbi elnökei közül BAKSA Csaba, BÉRCZI István, BREZSNYÁNSZKY Károly, HAAs János és KECSKEMÉTI Tibor, a főtitkárok közül CSERNY Tibor és Halmai János, a szerkesztők közül KázMÉR Miklós, KRIVÁnNÉ HorvÁtH Ágnes (egyben 2008 óta ügyvezetô titkár, illetve igazgató), PIROS Olga és SzTANó Orsolya által nyújtott információkat építettem be, illetve figyelembe vettem szíves megjegyzéseiket. Végül, de nem utolsósorban, számos adatot és megjegyzést köszönhetek ZIMMERMANN Katalinnak, az MFT 1986-2007 közötti ügyvezető titkárának. Mindnyájuknak ezúton szeretném hálás köszönetemet kifejezni. A képek válogatásához és reprodukálásához nyújtott segítségért PIROS Olgának, a diagramok megrajzolásáért ToPA Boglárka Annának tartozom köszönettel.

\section{Irodalom — References}

Dudich E., SzéKyné Fux V. \& Dobos I. 1998: A Magyarhoni Földtani Társulat harmadik félévszázada. — Magyarhoni Földtani

Társulat, Budapest, $124 \mathrm{p}$.

JÁMBOR Á. 2006: A magyar földtani bibliográfia helyzete. — Földtani Közlöny 136/1, 163-168.

KÁZMÉr M. 2004: Az Általános Földtani Szemle régi-új arca. — Általános Földtani Szemle 28, 5-7.

Косн A. 1902: A Magyarhoni Földtani Társulat 50 éves múködésének története. — Földtani Közlöny 32, 165-187.

NemeCz E. 1970: Újabb száz év elé. — Földtani Közlöny 100, 1-2.

SCHMIDT S. 1880: A magyarhoni földtani társulat 30 éves munkássága. — Földtani Közlöny 30, 2-15.

TASNÁdi KubaCsKa A. 1970: Száz éves a Földtani Közlöny. — Földtani Közlöny 100, 3-10.

Vendl A. 1958: A százéves Magyarhoni Földtani Társulat története. — Tankönyvkiadó, Budapest, 276 p.

Kézirat beérkezett: 2020. 02. 24. 


\section{Adattár}

\section{Szerkesztés}

\section{Szerkesztôk, felelős szerkesztők (névsorukat 1. lentebb)}

Már az MFT 1856-os második alapszabálya úgy fogalmazott, hogy a Társulat elsố titkára ,szerkeszti az évkönyvet és más kiadandó munkálatokat”, és a másodtitkár ,,az elsőnek segéde, szükség esetében helyettese" [M.II: 199-200]. A számos ízben módosított alapszabálynak e része sokáig nem változott, így a Földtani Közlönyt az MFT elsố titkára szerkesztette a másodtitkár segítségével egészen 1948-ig. 1949. II. 16-án új alapszabályt fogadtak el, és kilátásba helyezték, hogy a belügyminiszteri jóváhagyás után megjelentetik a Földtani Közlönyben [79: 127]. Ez azonban nem történt meg, és KeRTAI György elnök 1962. V. 9-i közgyűlési megnyitójában azt a meglepő bejelentést tette, hogy „,a Társulat felszabadulás utáni első új alapszabályát terjesztjük jóváhagyásra a közgyưlés elé” [92: 255]. Ez az alapszabály nyilván a létező gyakorlatot szentesítette, amikor 6. és 8. §-aiban rögzítette: ,a Földtani Közlönynek vagy a Társulat egyéb kiadványainak felelős szerkesztőjét az Elnökség javaslatára a Közgyưlés választja meg. Mellette a Választmány által kijelölt Szerkesztő Bizottság múködik. A felelős szerkesztő és a technikai szerkesztő tanácskozási joggal részt vesz a Választmányi üléseken”, és ,,a felelős szerkesztő tevékenységéért közvetlenül az elnöknek felelős" [92: 368-369]. 1951-ben és az 1952-ben valóban a közgyúlés választotta meg a (felelôs) szerkesztőt (Meisel Jánost [81: 346], majd BALogh Kálmánt [82: 325]), BALOGH lemondása után ToKODY Lászlót már az Elnökség bízta meg 1953. III. 6-án [83: 214], VADÁsz Elemér felelő szerkesztôi megbízásának mikéntjéról és dátumáról a Közlöny nem tudósított. A felelős szerkesztô státusán az 1967. III. 16-i alapszabály változtatott, melynek 8. §-a szerint a Földtani Közlöny felelős szerkesztője, egyben a szerkesztőbizottság elnöke a Társulat mindenkori elnöke. A Társulat ,egyéb kiadványait a megfelelő szakosztály, területi osztály, szakcsoport vezetôsége szerkeszti.” [97: 362]. Az újabb változást az 1997. III. 19-i alapszabály-módosítás hozta, melynek nyomán létrejött a főszerkesztői tisztség. A főszerkesztő és a szerkesztőbizottság feladatait részletesen szabályozza a társulati ügyrend.

\section{Technikai szerkesztők (névsorukat 1. lentebb)}

A felelős szerkesztő (majd a fôszerkesztô) munkáját segítő technikai szerkesztőt először az 1962-es alapszabály említi, de lényegében már a 78. kötettôl e minőségben múködött SzUROVY Géza, illetve az ôt helyettesítő Jugovics Lajos, aki az 1949. II. 16-i és az 1950. IV. 30-i tisztújító közgyúlésen a Társulat tisztikarának névsorában „szerkesztő” megjelöléssel szerepel [79: 128, 80: 225]. Az elnökség valószínúleg Jugovicsnak a MÁFI-ba való távozása után 1950. IX. 26-án ,elhatározta, hogy a Földtani Közlöny szerkesztésével és másodtitkári teendőkkel, addig is, amíg a választmány az ügyben határoz JAKUCS Lászlónét bízza meg” [80: 440]. JAKUCS Lászlóné (újbóli házasságkötése után VÉGH Sándorné) az 1952. évi közgyúlés által megválasztott új vezetôség névsorában szakszerkesztőként szerepelt [82: 325]. A Közlöny füzeteinek borítóján 1953-ban [83] a „,szerkesztő”, majd a „technikai szerkesztő" titulus olvasható, ez utóbbi megnevezés került be az 1962-es alapszabályba is, bár mindig magasan kvalifikált szakmabeliek töltötték be e fontos tisztséget. 1997 [127] — a főszerkesztői poszt bevezetése — óta általában két, továbbra is szakmabeli kolléga tölti be e tisztséget. 2019-ben [149], a technikai szerkesztők személyének megváltozását hozó átmeneti évben, számonként változott a technikai szerkesztői stáb összetétele. A technikai szerkesztôt az 1967-es alapszabály szerint a választmány [97: 362], az 1991-es alapszabály szerint az elnökség [122: 130], a jelenlegi alapszabály 15 . § (3) szerint az elnökség véleményét figyelembe véve az elnök nevezi ki.

\section{Szerkesztőbizottság}

A Földtani Közlöny szerkesztésében az 1949. II. 16-i közgyưlés óta [79: 128] múködik közre állandó jelleggel egy — a választmány által a szakterületi reprezentativitás figyelembevételével megbízott — szerkesztőbizottság. Funkciójáról először VADÁsz Elemér nyilatkozott egy mondatban, miszerint ,a Szerkesztőbizottság súlyos feladata lesz a kéziratok megfellebbezhetetlen egységesítése" [80: 136]. Az 1962. V. 9-i alapszabály 6. § f) pontja szerint ,a Társulat kiadványainak Szerkesztő Bizottsága előkészíti és felülbírálja a Földtani Közlöny és más, alkalomszerú kiadvány szerkesztését.” A jelenlegi alapszabály 8. § (1) szerinti megnevezés (a Földtani Közlöny Szerkesztőbizottsága) a Közlönyre redukálja a testület hatáskörét, tagjait az elnök javaslata alapján a választmány hagyja jóvá (15. § (3)). Az 1949-ben megválasztott szerkesztőbizottságok névsorát 1. [79: 128], a későbbieket a Közlöny hátlapján vagy impresszumában. A Társulat elnöke 1967 óta egyben a szerkesztőbizottság elnöke is.

A lap számára egyébként korábban is több ízben alakult szerkesztőbizottság, érdemi tevékenységükre vonatkozóan azonban e cikk írója nem ismer dokumentumokat. Először 1883-ban fogadta el a közgyúlés a választmány azon javaslatát, hogy „A Közlöny kiállításának és tartalmának ellenőrzésére (...) szerkesztő bizottság alakíttassék, amelyhez mint a Közlöny igazgató-tanácsához a szerkesztő minden szükséges esetben véleményért fordulhasson, s a melynek döntô szava legyen arra nézve, hogy esetenként valamely közlemény kiadható-e a Közlönyben vagy sem” [13: 69]. Ennek a választmány által ajánlott tagjai BöcKH János, a MKFI igazgatója, HoFMANN Károly fógeológus (MKFI), KRENNER József múegyetemi tanár, a Magyar Nemzeti Múzeum Ásvány-Ốslénytárának vezetője és WARTHA Vincze, a József múegyetem tanára lettek [13: 2]. 30 évvel később az 1913. IV. 2-i választmányi ülés a Közlöny szerkesztésére ismét bizottságot alakított, ennek elnöke SCHAFARZIK Ferenc társulati elnök (geológia), tagjai EMSZT Kálmán (vegytan), LŐRENTHEY Imre (őslénytan), MAURITZ Béla (ásványtan és kőzettan), TimKó Imre (agrogeológia) választmányi tagok, előadója PAPP Károly (geológia) első titkár és MAROS Imre másodtitkár voltak [43: 108, 356]. Az év folyamán azonban nem sikerült valamennyi tagot egyszer sem összehívni, mert ,a soknemú elfoglaltság miatt” hol egyik, hol másik bizottsági tag hiányzott [44: 306-307]. PAPP Károly titkár javaslata ellenére a választmány szükségtelennek vélte a szerkesztőbizottság beiktatását az 1914-ben módosított alapszabályba, mert múködését ügyrendi kérdésnek tartotta [44: 101]. Az I. világháború alatti SCHAFARZIK-SCHRÉTER-féle reform kapcsán a választmány 1916. III. 1-én ismét életre hívta a szerkesztóbizottságot változatlan személyi összetétellel [46: 128]. Szerkesztóbizottság választását az alapszabályreformmal foglalkozó 1919. III. 20-i rendkívüli közgyúlésen is javasolták, de JugOvics Lajos felvetését érdekes módon éppen SCHAFARZIK Ferenc tartotta szükségtelennek, mondván, hogy a szerkesztés irányítása a választmányi tagok közül megválasztandó négytagú ügyvezető bizottság teendői közé fog tartozni [49: 61]. A Közlöny szerkesztése ezen érvénybe nem lépett új alapszabály 19. §a szerint egyébként már nem a titkár, hanem a választmány által tagjai közül választott külön szerkesztő feladata lett volna [49: 64].

Megjegyzés: A következő, általában a lapszámok címlapján vagy impresszumában feltüntetett adatok alapján készült névsorok nem minden esetben tükrözik a naptári éven belüli változásokat, 
illetve a társulati ciklusok és a naptári év eltérései vagy az egyes számok késése miatti diszkrepanciákat.

Szerkesztők, felelős szerkesztők, illetve főszerkesztők (127-től)

E-M.I: KovÁTs Gyula, M.II: Szabó József, M.III-M.V: HANTKEN Miksa

1 (1-5): WinKLER Benô, 1 (6-10): Bernáth József és Koch Antal, 2: BöckH János, Koch Antal, SAJóHelyi Frigyes, 3-6: SAJÓHELYi Frigyes, Telegdi Roth Lajos, 7-11: InKEy Béla, SCHMIDT Sándor, 12: Pethő Gyula, FranZENAU Ágoston, 13-15: Pethő Gyula, SchafarziK Ferenc, 16-19: Staub Móric, Szontagh Tamás, 20: Staub Móric, 21: Staub Móric, SzÁDeczKy Gyula, 22-28: Staub Móric, ZimánYI Károly, 29-30: LócZy Lajos, CHOLNOKY Jenő, 3136: PÁLFY Mór, 37-39: LÓRENTHEY Imre, GÜLL Vilmos, 40-42: PAPP Károly, Vogl Viktor, 43-44 (1-2): PAPP Károly, MARos Imre, 44 (34)-45: PAPP Károly, 46-48 (1-9): BALLENEGGER Róbert, PAPP Károly, 48 (10-12)-49: PAPP Károly, 50: LÁszLó Gábor, VoGL Viktor, 51/52: VENDL Miklós, ZELLER Tibor, 53-59:ZELLER Tibor, REICHERT Róbert, 60-62: REICHERT Róbert, SZTRÓKAY Kálmán, 63: REICHERT Róbert, PAPP Ferenc, 64-67: PAPP Ferenc, 68: PAPP Ferenc, KULHAY Gyula, 69: PAPP Ferenc, KulhaY Gyula, KóRÖssY László, 70: HORUSITZKY Ferenc, BARTKó Lajos (közrem. PAPP Károly), 71-73: TASNÁDI KuBACSKA András, ,73/74”: PAPP Ferenc, ,75/76”-77: VADÁsz Elemér, PAPP Ferenc, 78: VADÁsz Elemér, Szurovy Géza, 79-80 (1-3): VADÁsz Elemér, 80 (4-6)-81 (1-3): KeRTAI György, 81 (4-6)-82 (4-6): MeISEL János, 82 (7-9)-83 (4-6): BALOGH Kálmán, 83 (7-12): TOKODY László, 84-94: VADÁsz Elemér, 95 (1-2): KERTAI György, 95 (3)-97 (2): VADÁsz Elemér, 97 (3)-101: NEMECZ Ernő, 102-116: DANK Viktor, 117-121: HÁMOR Géza, 122-124: KeCSKEMÉTI Tibor, 125-126: BÉRCZI István

főszerkesztôk: 127-145 (1): CSÁszÁr Géza (23. ábra), 145 (2)-: SzTANó Orsolya (helyettes főszerkesztő 143-145 (1))

Az 1967. III. 16-i alapszabály 8.§-a szerint a Társulat „egyéb kiadványait a megfelelô szakosztály, területi osztály, szakcsoport vezetôsége szerkeszti. [97: 362]” Az 1945 utáni szakosztályi kiadványok szerkesztôit 1. DuDICH et al. (1998: 100)

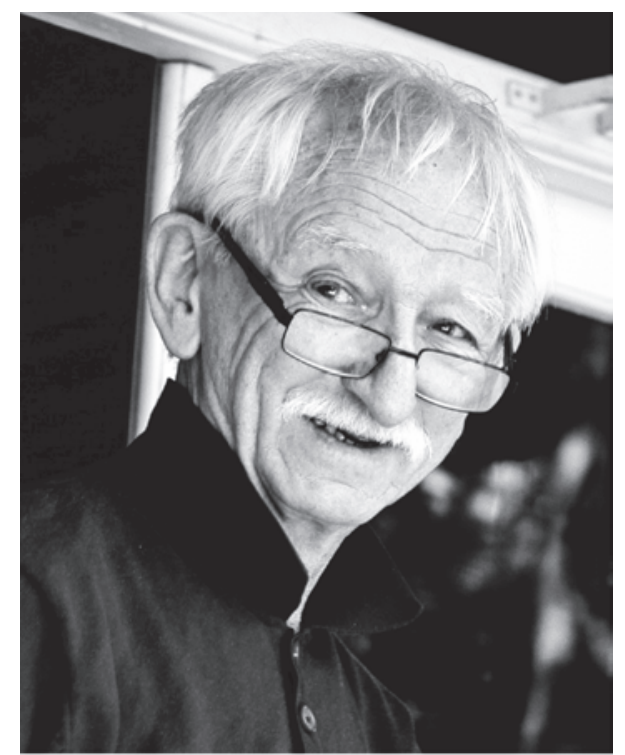

23. ábra. CsásZÁr Géza, a Földtani Közlöny főszerkesztője 1997-től 2015-ig [127-145 (1)] (Fotó CsÁsZÁr Gábor szivességéből)

Figure 23. Géza CSÁSZÁR, editor-in-chief of the Geological Bulletin from 1997 to 2015 [127-145 (1)] (Photo by courtesy of Gábor CSÁSZÁR)

\section{Technikai szerkesztők}

79-80: Szurovy Géza és Jugovics Lajos*, 80-94: JAKUCS Lászlóné = VÉGH Sándorné (24. ábra), 95 (1)-95 (2): VÉGH Sándorné és Meisel Jánosné, 95 (3)-112: MeIsel Jánosné (25. ábra), 113-121: KASZAP András (26. ábra), 122-124: KÁZMÉR Miklós (szerkesztő), 125-126: KASZAP András, 127-136 (2): PIROS Olga, KRIVÁnNÉ HoRVÁtH Ágnes** (a 125-126. kötet múszaki szerkesztője), 136 (3)-144 (2): Piros Olga, Simonyi Dezső, 144 (3-4): Piros Olga, Pentelényi Gábor, 145-148: Piros Olga, KrivánNé Horváth Ágnes, 149 (1): KovÁcs Zoltán, PIros Olga,

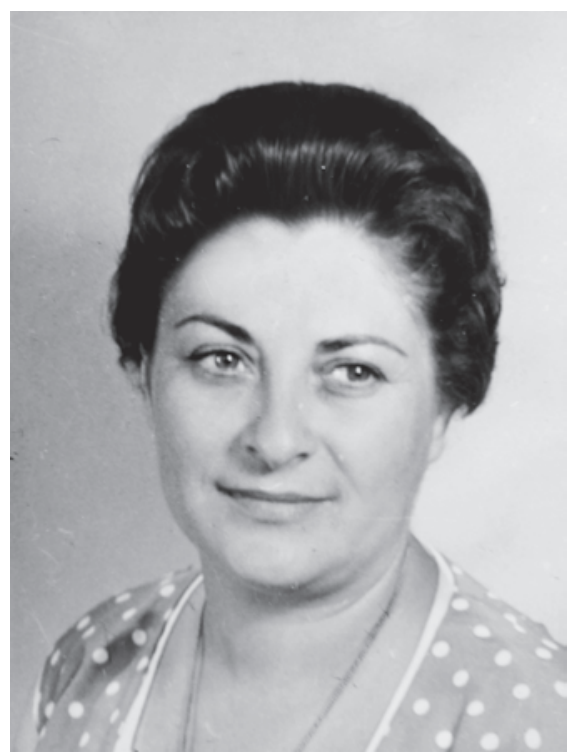

24. ábra. JAKUCS Lászlóné, később VÉGH Sándorné, NeUBRANDT Erzsébet, a Földtani Közlöny technikai szerkesztője 1950-től 1965-ig [80-95 (1)] (Fotó JAKUCS Erzsébet szivességéből)

Figure 24. Lászlóné JAKUCS, later Sándorné VÉGH Erzsébet NEUBRANDT, technical editor of the Bulletin from 1950 to 1965 [80-95(1)] (Photo by courtesy of Erzsébet JAKUCS)

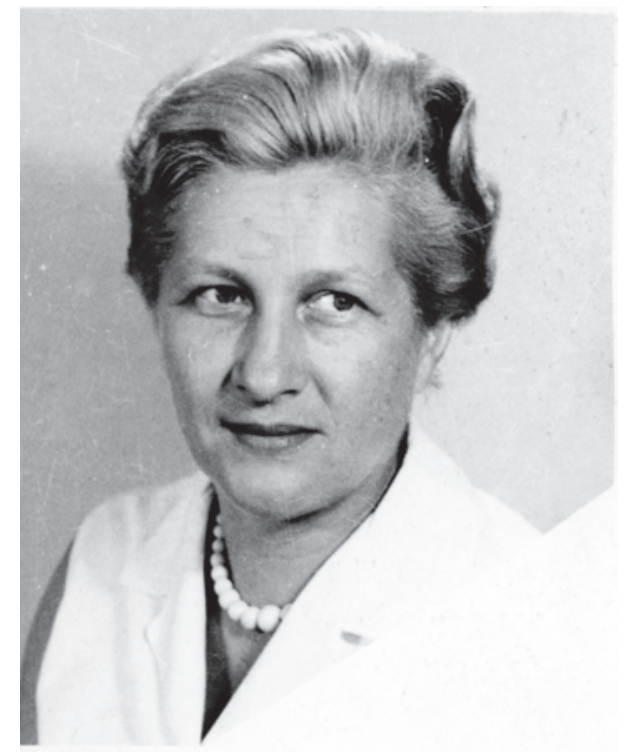

25. ábra. MeIsel Jánosné Eysztrich Róza, a Földtani Közlöny technikai szerkesztője 1965-től 1982-ig [95-112] (Fotó LőRINCZ Mária szivességéből)

Figure 25. Jánosné MEISEL, née Róza EYSZTRICH, technical editor of the Bulletin from 1965 to 1982 [95-112] (Photo by courtesy of Mária LöRINCZ) 


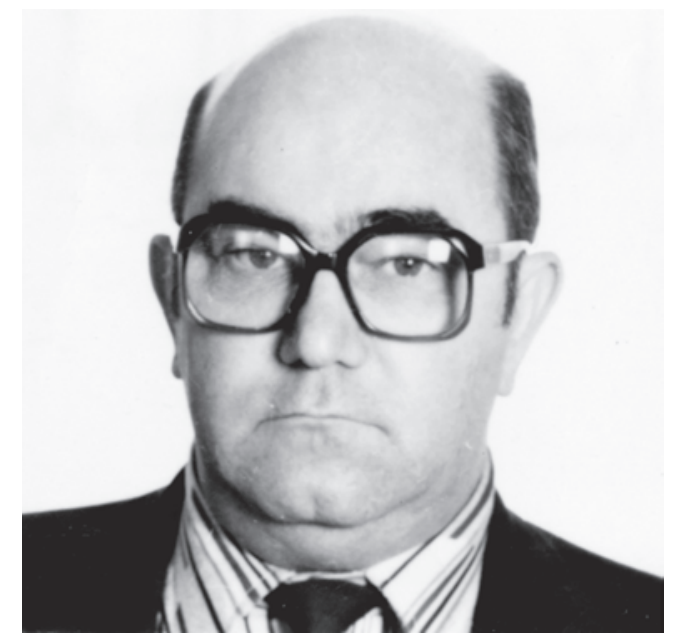

26. ábra. KASZAP András, a Földtani Közlöny technikai szerkesztője 1983-tól 1991-ig és 1995-től 1996-ig [113-121 és 125-126] (Fotó KASZAP Tamás szívességéből)

Figure 26. András KASZAP, technical editor of the Bulletin from 1983 to 1991 and from 1995 to 1996 [113-121 and 125-126] (Photo by courtesy of Tamás KASZAP)

149 (2): BABINSZKI Edit, KovÁcs Zoltán, 149 (3)-149 (4): BABINSZKI Edit, BARTHA István Róbert, KovÁCs Zoltán.

*Az akkoriban az ELTE Földtani Tanszékén (a „VADÁsZ-tanszéken”) dolgozó JUGOVICS nyilván SzUROVY Géza titkárt helyettesítette technikai szerkesztői minőségében [1. 80: 223]).

** A fő́titkári jelentések megnevezése szerint tördelő szerkesztô

\section{Kiadók}

A Földtani Közlönyt a tudományos társulatok államosításának periódusától (1949-1989) eltekintve mindig is a Magyarhoni Földtani Társulat adta ki.

E, M.I-M.V, 1-78: Magyarhoni Földtani Társulat, 79 (1-4): Múszaki és Természettudományi Egyesületek Szövetsége, 79 (58)-80 (4-6): Tudományos Folyóiratkiadó Nemzeti Vállalat, 80 (79)-83: Nehézipari Könyv- és Folyóiratkiadó Vállalat, 84-119: Akadémiai Kiadó, 120-: Magyarhoni Földtani Társulat

\section{Nyomdák (a nem budapesti nyomdák telephelyeivel)}

E: Lukács László ny., M.I: Herz János ny., M.II: Emich Gusztáv ny., M.III: Herz János ny, M.IV-M.V: Légrády testvérek ny.

1-3: Khór és Wein könyvny., 4-12: Légrády testvérek ny., 1350: Franklin-Társulat ny., 51-53: Magyar Tudományos Társulatok Sajtóvállalata Rt. Nyomda, 54-57: Királyi Magyar Egyetemi Nyomda, 58-59: Váci királyi országos fegyintézet könyvny. (Vác), 60: Királyi Magyar Egyetemi Nyomda, 61-62: Dunántúl Pécsi Egyetemi Könyvkiadó és Nyomda Rt. (Pécs), 63-71: Mérnökök Nyomdája, 72-73 (1-9)?: Kertész József könyvny. (Karcag), 73 (10-12): Élet Irodalmi és Nyomda Rt., „73/74”-78: Egyetemi Nyomda, 79 (1-8): Szikra Nyomda, 79 (9-12)-81 (1-3): Kultúra Nyomda, 81 (4-6): Athenaeum Nyomda, 81 (7-9)-82: Szikra Nyomda, 83: Egyetemi Nyomda, 84-119: Akadémiai Nyomda, 120 (1-2): Magyar Rádió ny., 120 (3-4)-121: MOL Nyrt. KutatásTermelési Ágazat Nyomda Üzeme (Szolnok) = 122-124: MOL Nyrt. Nyomda (Szolnok) $=125-132$ : Tisza Nyomda Kft. $($ Szolnok), 133-142: Innova-Print $($ Pomáz $)=143$ : F\&F Print Line
Kft. (Pomáz) = 144-148: P-R Innovation Kft. (Pomáz), 149-: Starkiss Kft. (Budaörs)

ny.: nyomdája; az egyenlőségjellel összekötött nevek egyazon nyomdát jelölik

\section{„Belsó társlapok” a Földtani Közlönyben}

13-15: A magyar kir. Földtani Intézet évi jelentése / Jahresbericht der k. ung. Geologischen Anstalt

40-43: Közlemények a Magyarhoni Földtani Társulat Barlangkutatási Bizottságából / Mitteilungen aus der Höhlenforschungskommission der Ungarischen Geologischen Gesellschaft

48-50: Hidrológiai Közlemények / Hydrologische Mitteilungen (előzménye a Hidrológiai Szakosztály külön rovata a 47. kötetben)

\section{Tematikus és különszámok, (*-gal jelölve:) dedikált kötetek/füzetek}

E számok egy része, különösen a supplementumok, gyakran külső (ipari, főhatósági, MTA, minisztériumi stb.) támogatással jelentek meg.

4 (az évfolyam mellékleteként): PošEPNÝ, F.: Geologischmontanistische Studie der Erzlagerstätten von Rézbánya in S.O.Ungarn. Légrády Testvérek, Budapest, 168 p.

27 (1-4, 5-7): „A millenniumi év végén”. (BöcKH J.: „A geológia fejlődésének rövid története Magyarországon 1774-1896ig”, valamint SchMidT S. és SCHAFARZIK F. cikkei a millenáris kiállítás bányászati, talajtani, balneológiai, földtani térképi és oktatási részeiről, SchafarziK F. és HALAVÁTs Gy. kongresszusi beszámolói.)

27 (8-10): SzÁdECZKy Gy.: A Sátoralja-Ujhelytől északnyugatra, Ruda-Bányácska és Kovácsvágás közé eső terület geologiai és kőzettani tekintetben. („egycikkes füzet”)

33 (7-9): A Bécsben tartott IX. Nemzetközi Geológiai Kongresszus után 1903. augusztus 28-tól szeptember 4-ig tervezett Budapest-Alföld-Alduna kirándulásra íratott kirándulásvezetők.

38 (5): Szabó-füzet (A vihnyei Szabó-szikla emléktáblájának 1908. május 30-i leleplezése alkalmából)

56*: Telegdi Roth Lajos jubileumi kötet (nem jelentek meg külön füzetek)

62*: ZIMÁNYI Károly jubileumi kötet (nem jelentek meg külön füzetek (5A. ábra)

$73(1-3)^{*}:$ KocH Antal emlékének ajánlva

79*: id. LóczY Lajos-emlékkötet

85*: A 70 éves VADÁsZ Elemérnek ajánlott kötet

93 (különszám): Agyagásványfüzet, benne külön „A Földtani Társulat Agyagásványtani Szakcsoportjának DTA-ankétje"(1960.

IV. 25.) előadásai is. Felelős szerkesztô: NEMECZ Ernó

98 (1): A Szénhidrogénföldtani Kollokvium (1967. május 15.) és a „Gépi adattárolás és adatfeldolgozás a földtani kutatásban” ankét (1967. május 29.) előadásai

101 (2-3): A Neogén Kollokvium (Colloquium on the Neogene) (1969. szeptember 4-9.) előadásai

103 (3-4): A „Gyakorlati eredmények bemutatása az üledékföldtan tárgyköréből” c. ankét (Pécs, 1972. november 22-24.) előadásai

104 (2): A 125 éves Magyarhoni Földtani Társulat ünnepi közgyúlésének (1973. április 25-27.) előadásai

105 (különszám): A recski vándorgyúlés (1974. október 3-4.) előadásai. 
106 (2): A centenáriumi BöcKH Hugó emlékülés (1974. október 28.) előadásai

106 (különszám): A Szénhidrogénföldtani Ankét (1974. november 18-19.) előadásai

107 (3-4): A Tektonikai Ankét (MFT Általános Földtani Szakosztály, 1975. november 10.) elôadásai

108 (1): Az MTA-MFT tatabányai vándorgyúlésének (1975. október 2-3.) előadásai

109 (3-4): Az I. Országos Bányaföldtani Ankét (Pécs, 1977. április 20-22.) előadásai

110 (3-4): Az Ốsföldrajzi Ankét (1978. november 9-10.) előadásai.

124 (2): Fodor L., Magyari Á., Fogarasi A. és Palotás K.: Tercier szerkezetfejIődés és késő paleogén üledékképződés a Budaihegységben. A Budai-vonal új értelmezése (,egycikkes füzet”)

130 (2): „A ma geológiája a holnapért” / „The Geology of Today - for Tomorrow" nemzetközi konferencia (1999. június 2122.) elôadásainak egy része.

132 (különszám): A földtörténeti közelmúlt környezetváltozásai a Pannon-medencében: Fejezetek a hazai negyedidőszakkutatás legújabb eredményeiből. A „Negyedidőszak-kutatás és az ahhoz kapcsolódó kérdések" ankét (2000. március 29.) előadásai

140 (4)*: A Balaton és környéke földtani kutatásának legújabb eredményei (a 375. éves Eötvös Loránd Tudományegyetemet köszöntő füzet)

148 (1)*: MindSZENTY Andreának ajánlott tematikus szám (T)

149 (3 és 4)*: Tisztelgés HoRváth Ferenc professzor munkássága előtt címú tematikus számok

\section{Elófizetési díjak}

A Földtani Közlönyt — az 1950-60-as évektôl eltekintve, amikor a társulati tagok kedvezményes előfizetési díjért jutottak hozzá [vö. 92: 367, 93: 422, 97: 360] — minden társulati tag megkapta, tehát a tagdíj egyben előfizetési díj is volt (27. ábra, l. az I. táblázatot). 2001-től a társulati tagok is csak külön előfizetési díjért jut-

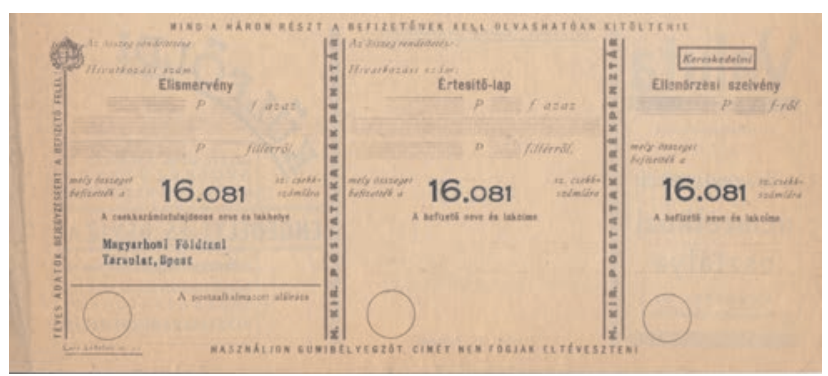

27. ábra. A Magyarhoni Földtani Társulat részére elỏrenyomtatott postai utalvány az 1926-1945 közötti időszakból

Figure 27. Postal voucher pre-printed for the Hungarian Geological Society (from the period 1926-1945)

hatnak hozzá a laphoz, illetve 2013-2014 között lehetőség volt csak az online elérhető digitális változat előfizetésére. Ez 2015 óta a tagdíj ellenében, 2017 óta pedig ingyen elérhetô, 1. a II. táblázatot. A Közlönyt 2000 előtt is egyes időszakokban elő lehetett fizetni, illetve számonként megvásárolni, erre vonatkozóan 1. a III. táblázatot.

\section{Terjedelem (oldalszám)}

L. a 28. ábrát
I. táblázat. Éves társulati tagdij 1871-2000 között

Table I. Annual membership fee of the Society between 1871-2000

\begin{tabular}{|c|c|c|c|}
\hline Év [kötet) / year /volume] & $\begin{array}{c}\text { Rendes, ill. aktiv tag / } \\
\text { ordinary or active } \\
\text { member }\end{array}$ & $\begin{array}{l}\text { Nyugdijas (ny), } \\
\text { tanuló (t) / retired } \\
\text { (ny), student (t) }\end{array}$ & Forrás / source \\
\hline $1871-1891[1-21]$ & $5 \mathrm{frt}$ & - & $\begin{array}{l}\text { belsổ boritó / } \\
\text { inside wver }\end{array}$ \\
\hline $1892-1899$ [22-29] & $5 \mathrm{frt}=10 \mathrm{~K}$ & - & $\begin{array}{l}\text { belsö boritó / } \\
\text { inside over }\end{array}$ \\
\hline $1900-1919$ [30-49] & $10 \mathrm{~K}^{*}$ & - & $\begin{array}{l}\text { belsô boritó / } \\
\text { inside wver }\end{array}$ \\
\hline $1920[50]$ & $20 \mathrm{~K}$ & - & [50: 63] \\
\hline $1920[50]$ & $50 \mathrm{~K}$ & - & [51/52: 80$]$ \\
\hline $1923[53]$ & $200 \mathrm{~K}$ & - & [53: 103] \\
\hline $1924[54]$ & n. a. / n.d. & - & \\
\hline $1925[55]$ & $\begin{array}{l}85000 \mathrm{~K}(=5 \\
\mathrm{aK})\end{array}$ & - & [55: 248] \\
\hline $1926[56]$ & $100000 \mathrm{~K}=8 \mathrm{P}$ & - & $\begin{array}{l}\text { belsö boritó / } \\
\text { inside wver }\end{array}$ \\
\hline $1927-1944[57-, 73 / 74 ”]$ & $8 \mathrm{P}$ & - & $\begin{array}{l}\text { belsö boritó / } \\
\text { inside wver }\end{array}$ \\
\hline 1945-46 [..75/76"] & n. a. $/ n . d$. & n. a. $/ n$. d. & \\
\hline $1947-1949$ [77-79] & n. a. $/$ n. d. (24 Ft?) & n. a. $/ n$. d. & \\
\hline 1950-195? [80-8?] & $36 \mathrm{Ft}$ & $\begin{array}{l}12 \mathrm{Ft}(\mathrm{ny}), 10 \mathrm{Ft} \\
(\mathrm{t})\end{array}$ & [80: 226] \\
\hline $195 ?-1964$ [8?-94] & n. a. / n. d. & $\begin{array}{l}16 \mathrm{Ft} \text { ? (ny), 16 Ft } \\
(\mathrm{t})\end{array}$ & [95:364] \\
\hline $1965-1968$ [95-98] & $60 \mathrm{Ft}[95: 364]$ & $\begin{array}{l}24 \mathrm{Ft} \text { ? (ny), } 24 \mathrm{Ft} \\
\text { (t) }\end{array}$ & [95:364] \\
\hline 1969-1978 [99-108] & $80 \mathrm{Ft}$ & $32 \mathrm{Ft}(\mathrm{ny}, \mathrm{t})$ & $\begin{array}{l}\text { [100: } 333, \\
\text { 109: 330] }\end{array}$ \\
\hline 1979-1984 [109-114] & $140 \mathrm{Ft}$ & $\begin{array}{l}50 \mathrm{Ft}(\mathrm{ny}), 40 \mathrm{Ft} \\
(\mathrm{t})\end{array}$ & [109: 330] \\
\hline 1985-1989 [115-119] & $260 \mathrm{Ft}$ & $\begin{array}{l}50 \mathrm{Ft}(\mathrm{ny}), 40 \mathrm{Ft} \\
(\mathrm{t})\end{array}$ & $\begin{array}{l}{[115: 357,} \\
120: 2]\end{array}$ \\
\hline $1990-1994[120-124]$ & $500 \mathrm{Ft}$ & $100 \mathrm{Ft}(\mathrm{ny}, \mathrm{t})$ & [120:2] \\
\hline 1995-1999 [125-129] & $800 \mathrm{Ft}$ & $300 \mathrm{Ft}(\mathrm{ny}, \mathrm{t})$ & \\
\hline $2000[130]$ & $1200 \mathrm{Ft}$ & $500 \mathrm{Ft}(\mathrm{ny}, \mathrm{t})$ & \\
\hline
\end{tabular}

Röviditések: aK: aranykorona, frt: osztrák értékủ forint, Ft: forint, K: korona, n. a. = nincs adat, P: pengö.

*A Barlangkutatási Szakosztály külön tagsági dija 1913-17 között 3, utána 5 K, a Hidrológiai Szakosztály külön tagsági dija 1917-ben 5 K [48: 92].

Házastársi, ill. regisztrációs tagi dij (kiadványok nélkül): 1969?-1984: $60 \mathrm{Ft}$, 1985-1994: 100 Ft, 1995-1999: 400 Ft, középiskolások tagsági dija: 19791984: $32 \mathrm{Ft}$.

Abbreviations: aK: aranykorona (gold crown), frt: forint (gulden, Austrian value), Ft: forint, K: Austro-Hungarian korona, n. $d .=$ no data, P: pengö.

*The special membership fee for the Speleological Section was 3 K between 191317, then 5 K, that of the Hydrological Section was 5 K for 1917 [48: 92].

Membership fee for the spouse of for registered members (no publications are included): 600 Ft from 1969? to 1984, $100 \mathrm{Ft}$ from 1985 to 1994, $400 \mathrm{Ft}$ from 1995 to 1999, membership fee for secondary school students.

\section{Formátum}

1871-1878 [1-8]: kis oktáv, 1879-2007 [9-137]: nagy oktáv majd B5, 2008-tól [138-] A4.

\section{Példányszám (l. a 29. ábrát is)}

A Földtani Közlöny példányszámára vonatkozóan az első évtizedekre nem sikerült konkrét adatokat találni, de a (nem tag) elófizetők és a nagy számú cserepartner miatt jócskán meghaladta a társulati tagok számát. Az előfizetők száma az 1880-as évek elején 20, 1885-ben már 50 volt [16: 56], és 1918-ig 50-60 között stabilizálódott. A csereviszonyosok száma fokozatosan nőtt, a kezdeti kb. 25-ről 1917-re 210-ra. Az elsô számszerú adatokat az 1908-1918-as időszakra vonatkozóan ismerjük, ezalatt a példányszám a társulati 
II. táblázat. A Földtani Közlöny éves elöfizetési díja 2001-től (Ft)

Table II. Annual subscription fee of the Bulletin from 2001 (forint)

\begin{tabular}{|c|c|c|c|c|c|}
\hline Év / year & $\begin{array}{l}\text { Aktív dolgozó } \\
\text { / employee }\end{array}$ & $\begin{array}{c}\text { Nyugdijas vagy } \\
\text { tanuló / retikd or } \\
\text { student }\end{array}$ & $\begin{array}{c}\text { Intézmény, cég / institution, } \\
\text { company }\end{array}$ & $\begin{array}{l}\text { Csak online, aktív dolgozó } \\
\text { / employee, on-line only }\end{array}$ & $\begin{array}{c}\text { Csak online, nyugdijas és } \\
\text { tanuló / retived or student, } \\
\text { on-line only }\end{array}$ \\
\hline $2001-2007$ & 3800 & 2800 & n. a. $/$ n. $d$ & - & - \\
\hline $2008-2012$ & 5000 & 5000 & n. a. $/ n \cdot d$ & - & - \\
\hline $2013-2014$ & 7000 & 5000 & n. a. $/ n . d$ & 5000 & 3000 \\
\hline $2015-2016$ & 7500 & 5500 & 10000 & $\begin{array}{l}\text { tagdij fejében / included } \\
\text { in the membership fee }\end{array}$ & $\begin{array}{l}\text { tagdij fejében / included } \\
\text { in the membership fee }\end{array}$ \\
\hline $2017-$ & 7500 & 5500 & 10000 & ingyenes / free & ingyenes / free \\
\hline
\end{tabular}

Rövidítések: $\mathrm{n}$. a. = nincs adat.

Abbreviations: $n$. $d$. $=$ no data.

III. táblázat. A Földtani Közlöny füzeteinek, illetve köteteinek árai egyes időszakokban (ha a forrás nincs megjelölve, a füzeteken feltüntetett ár)

Table III. Price of single issues or volumes of the Bulletin (from the back cover if the source is not specified)

\begin{tabular}{|c|c|c|}
\hline Évfolyam / volume & $\begin{array}{c}\text { Füzet ára / price per } \\
\text { issue }\end{array}$ & $\begin{array}{c}\text { Kötet ára [forrás] / price } \\
\text { per volume [source] }\end{array}$ \\
\hline $1-3$ & n. a. / n.d. & $2 \mathrm{frt}$ \\
\hline 4-9 & n. a. / n. d. & 3 frt $[4: 30]$ \\
\hline $10-12$ & n. a. $/ n . d$. & $4 \mathrm{frt}^{*}$ \\
\hline $13-$ & n. a. $/ n . d$. & $5 \mathrm{frt}[13: 76]=10 \mathrm{~K}$ \\
\hline 50 & n. a. / n. d. & $100 \mathrm{~K}$ \\
\hline $81-84$ & $6 \mathrm{Ft}$ & $12 \mathrm{Ft}$ \\
\hline $85-97$ & n. a. / n. d. & $40 \mathrm{Ft}^{* * *}$ \\
\hline $98-106$ & $10 \mathrm{Ft}$ & $40 \mathrm{Ft}$ \\
\hline $107-114$ & $19 \mathrm{Ft}$ & $76 \mathrm{Ft}$ \\
\hline $115-118 / 2$ & $24 \mathrm{Ft}$ & $96 \mathrm{Ft}$ \\
\hline $118 / 3-120 / 1-2)$ & $36 \mathrm{Ft}$ & $144 \mathrm{Ft}$ \\
\hline $120 / 3-4-122$ & $100 \mathrm{Ft}$ & $400 \mathrm{Ft}$ \\
\hline 131 & n. a. $/ n \cdot d$. & $\begin{array}{l}1200 \mathrm{Ft}+\hat{\mathrm{FA}} / 1200 \\
\mathrm{Ft}+\mathrm{VAT}\end{array}$ \\
\hline
\end{tabular}

A röviditéseket 1. az I. táblázatban. A Földtani Értesítő 1947-es kötete 10 Ft-ba, az 1948-as 20 Ft-ba került.

*Az 1 Ft árú Földtani Értesítővel együtt.

**Tagoknak $12 \mathrm{Ft}$, majd $16 \mathrm{Ft}$.

For abbreviations, see Table I. The 1947 volume of Földtani Értesitö was 10 Ft and the 1948 volume was $20 \mathrm{Ft}$.

* Including the Földtani Értesitö for $1 \mathrm{Ft}$.

** For members $12 \mathrm{Ft}$, then $16 \mathrm{Ft}$.

taglétszám intenzív növekedése miatt csaknem megduplázódva 650-ról 1200-ra nôtt.

A fölöspéldányokat különbözőképpen hasznosították. 1874ben például a vallás- és közoktatásügyi miniszter a Társulat kérésére utasította az ország különbözó középiskoláit a Közlöny elsố három kötetének könyvtáraik számára való beszerzésére [5: 46]. 1876-ban a társulat régebbi kiadványai s a Közlöny addigi évfolyamai Kilián Frigyes budapesti egyetemi könyvárusnak adattak át bizományba [7: 25]. 1878-ban ,,a fennmaradó 70 példány a könyvkereskedés útján volt a közönség szükségletének hozzáférhetôvé téve" [9: 54]. A Társulat harmincéves jubileumakor a régebbi kiadványokat hazai középiskoláknak és közkönyvtáraknak osztották szét [FÉ.1: 29, 125-126].

1919-tôl 1952-ig ismét nem ismerünk példányszámadatokat. A tagszám 300-400 között változott, az előfizetők száma elszórt adatok alapján 15-20 körül alakult, a cserepartnerek számára vonatko- zóan - egy kivétellel — nincsenek adatok, de vélhetőleg a korábbinál kisebb lehetett.

A példányszám az 1948-at követô időszakban is — egészen az ezredfordulóig — elsôsorban az MFT taglétszámától függött, az ezen felüli mennyiséget az 1990-es évek elejéig a cserepéldányként, valamint a postai hírlap-előfizetés útján értékesített példányok iránti igény is érdemben befolyásolta. Az impresszumban szereplő adatok szerint 1951-1953 során [81-83] 500 és 650 között ingadozott, majd 1954-ben [84], az Akadémiai Kiadóhoz kerülés után hirtelen 1000-re, 1955-ben [85] 1300-ra ugrott, és 1969-ig [99] — a példányszámnak az impresszumból való eltûnéséig — e szinten stabilizálódott. Az 1978-ban hirtelen 1500 fölé ugró társulati taglétszám nagy kihívást jelenthetett a Társulat számára, mivel már az 1976-os főtitkári jelentés szerint is ,,az ismert papírbeszerzési és nyomdaipari nehézségek miatt Közlönyünk példányszámának emelését egyelőre nem tudtuk megnyugtató módon rendezni. Hasonló a helyzet a Földtani Kutatás példányszámával" [106: 343344]. A taglétszám 1982-ban érte el csúcsát (1680fő). Az 1980-as években így általában 1900-2100 példányban nyomtatták a Közlönyt, bár a taglétszám 1989-ig fokozatosan 1250-re csökkent. A tagoknak megküldött példányokon felül mintegy 160 példány jutott az ELTE TTK Földtani Tanszék (VADÁsz Elemér korábbi tanszéke) könyvtára számára, bel- és külföldi cserére. 60 példány különböző hazai könyvtárakba került, a tartalékon felüli fennmaradó példányokat az Akadémiai Kiadó a Posta lapterjesztő hálózatán

$\rightarrow$ 28. ábra. A Földtani Közlöny eddig megjelent 149 kötetének évi füzetszáma (zöld pont), illetve magyar (piros oszlop) és idegen nyelvủ oldalszáma (kék oszlop), a tartalomjegyzék és mutatók nélkül, a folyóirat formátumváltási éveinek bejelölésével. Grafika: Topa Boglárka Anna

$\rightarrow$ Figure 28. Number of issues per year (green dots), number of pages per year in Hungarian (red column) and in foreign languages (blue column), without table of contents and indices, of the 149 volumes of the Bulletin published so far. Years of change of the print format of the journal are also shown. Graphics: Boglárka Anna Topa

$\rightarrow \rightarrow$ 29. ábra. A Földtani Közlöny eddig megjelent 149 kötetének évi példányszáma. Piros: tagi példányok, zöld: előfizetői példányok, kék: cserepéldányok: fekete: egyéb példányok, illetve összes (nem részletezett) példány. $\mathrm{A}$ telt színủ oszlopok adatokon, a halványabbak becsléseken alapulnak, a szin annál erősebb, minél megbizhatóbb a becslés. Narancssárga vonal: a Magyarhoni Földtani Társulat teljes taglétszáma. A görbe folytonos része adatokon, a pontozott becsléseken alapul. Grafika: ToPA Boglárka Anna

$\rightarrow \rightarrow$ Figure 29. Number of annual copies of the 149 volumes of the Bulletin published so far. Red column: members' copies, green column: subscribers' copies, blue column: exchange copies: black column: other copies or unspecified copies. Full-colour columns are based on data, paler ones are estimates, the stronger the color, the more reliable the estimate is. Continuous / dotted orange line: (total) membership of the Hungarian Geological Society, based on data / estimated. Graphics: Boglárka Anna ToPA 

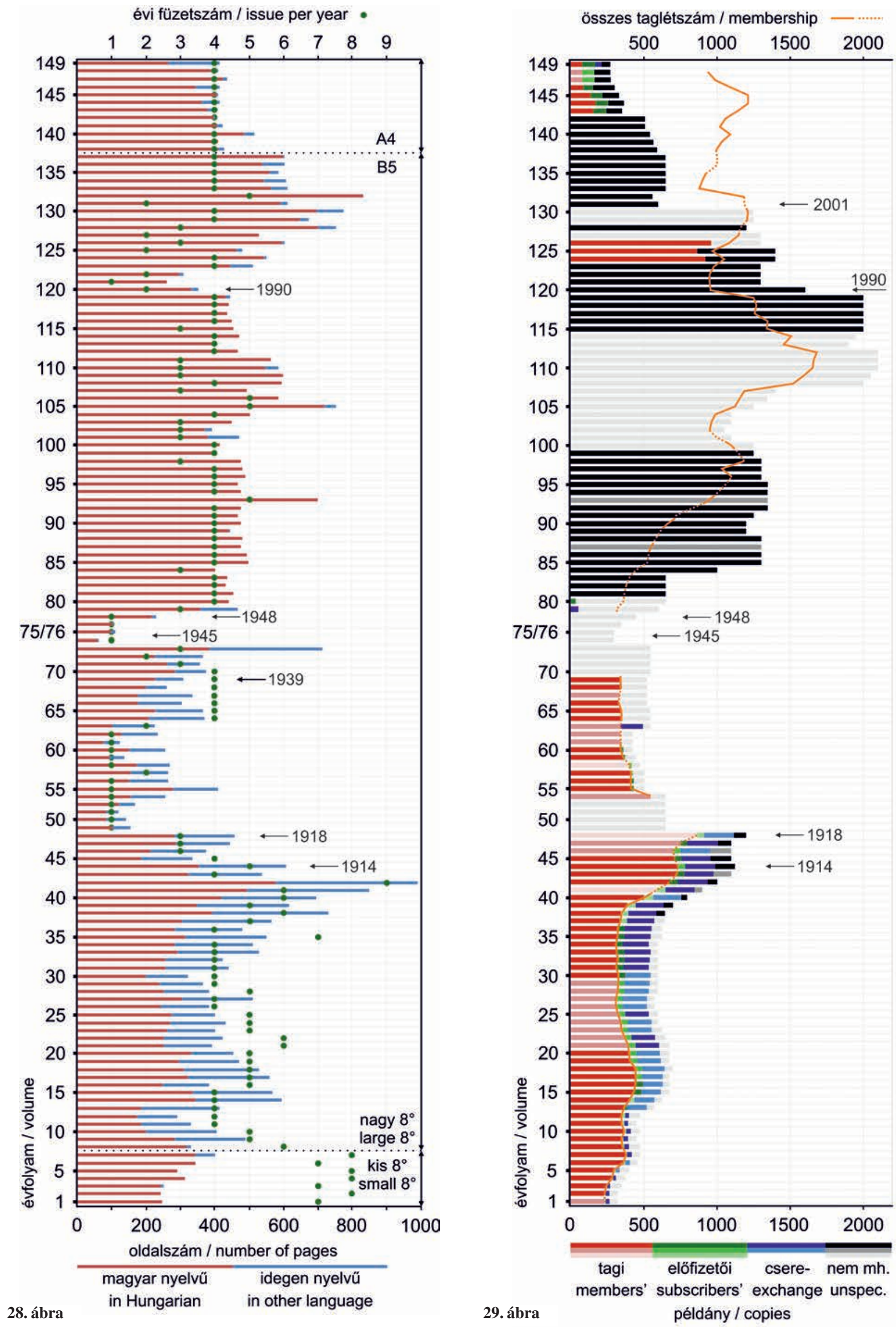
keresztül kül- és belföldi megrendelóknek értékesítette (ZIMMERMANN K. közlése alapján).

A rendszerváltás után a példányszám csökkenni kezdett. Ennek fő oka a taglétszámnak az 1980-as évek rekordjához képesti visszaesése volt. Emellett az Akadémiai Kiadótól való megválás miatt a Magyar Postával is a Társulatnak kellett (volna) újraszerződnie, de ez a postai előfizetési díjak drasztikus emelkedése miatt meghiúsult. Így száznál is több postai előfizető (magánszemélyek, intézmények, könyvtárak) esett ki. A postaköltségek növekedése és az ELTE-t sújtó költségvetési megszorítások miatt a könyvtári cserepéldányokra vonatkozó igény is visszaesett. Az erôs visszaesés után ([119]: $2000 \mathrm{db}$, [122]: $1300 \mathrm{db}$ ), a nyomtatott példányszám 1200-1300 között stabilizálódott.

A külön előfizetési díj 2001-es [121] bevezetése a példányszám drasztikus visszaesését hozta, ekkor a külsô eladásokkal együtt 600 példányt nyomtattak. Ez a nagyságrend egy évtizedig stabil maradt. Az online elérhetôséggel (2013-tól) a példányszámok újból erősen csökkenni kezdtek. A 2019. évi [149] 270 nyomtatott példány megoszlása: 81 tagi megrendelés, 28 tiszteleti és örökös tagi járandóság, 86 intézményi és céges megrendelés, 50 az MBFSz szakkönyvtárának (cserelapként), 25 társulati tartalék céljára készült.

\section{Csereviszonyok}

A Földtani Közlönynek sokáig igen fontos „,barterszerepe’” volt a (főleg külföldi) szakmai társulatok és intézmények kiadványainak beszerzésében. A Társulatnak már 1872-ben 26 ilyen csereviszonyosa volt. Mivel az 1876-os közgyúlés határozata nyomán a társulati könyvtárat az MKFI könyvtárhelyiségeiben helyezték el, ill. azzal egyesítették [7: 24], az elkövetkező időszakban a cserék jelentôs részben az MKFI könyvtárát gyarapították, noha az éves beszámolókban gyakran külön adták meg a társulat, illetve az MKFI csereviszonyosainak számát (velük az Intézet a számára ingyen átengedett példányok segítségével bonyolította le a cserét, az Intézeten keresztüli cserék száma az 1880-as évek elején már 100 volt. 1886-ban cserék, de ajándékozás útján is körülbelül 100 kötet meg füzet érkezett be „,mely kiadványok legnagyobb része a fennálló szövetség értelmében a magy. kir. földtani intézet könyvtárában helyeztetett el; a megmaradt rész pedig a magy. kir. József-múegyetemen a lefolyt évben rendszeresített geológiai tanszék könyvtárának engedtetett át [17: 53]. A Közlöny kétnyelvûsége előnyösen hatott a cserekapcsolatokra (,a külföldi társulatok mindinkább keresik velünk a szellemi összeköttetést" [18: 109]). 1904-ben a közgyúlésen elhangzott, hogy „,csereviszonyunk növekedése legjobban bizonyítja azt, hogy Közlönyünk rendeltetésének megfelel, mert társulatunk egyetlen esetben sem maga kérte a csere megindítását" [34: 81]. A századfordulón a Társulat közvetlenül 70, az MKFI-n keresztül 100 partnerrel állt cserekapcsolatban. 1910-ben 200 cserepéldányt nyomtattak a Közlönyből [40: 215]. 1914-ben a Társulatnak 102, az Intézetnek 101 külföldi cserepartnere volt [45: 130]. 1915-ben már arról tudósított a titkár, hogy „a nagy külföldnek szóló cserepéldányokat egyelőre raktároztuk, minthogy a háború miatt még a semleges államokba való szétküldés is a legnagyobb nehézségekbe ütközik" [46: 29]. A választmány 1916. I. 5-én a MKFI átirata nyomán a Társulat az általa adminisztrált 96 csereviszonyos folyóirat kezelését átadta az Intézetnek azzal, hogy az a szükséges folyóiratokat tartsa meg a saját könyvtárában, a többit elsősorban a budapesti egyetemek földtani tanszékeinek küldje meg mint az MFT ajándékát. [46: 126-127, 47: 280-282].

Az 1919-1949 közti időszakból mindössze annyi információnk van a cserekapcsolatok lebonyolításának mikéntjéról, hogy az MKFI igazgatóságának 219/1933 sz. átirata szerint ,, a csereviszonyokat a jövőben az Intézet látja el”, amihez 150 kötet Közlönyt kértek, és cserébe 50-50 Évkönyvet és Évi Jelentést, illetve 10 példány Geologica Hungaricát adtak [VENDL 1958: 183). Miután 1948 végén a Közlöny kiadása kikerült a Társulat kezéből, SZUROVY Géza titkár 1950-es közgyúlési beszámolójában sietett leszögezni, hogy „külföldi cserepéldányainkat továbbra is magunknak tartjuk fönn (...) A Földtani Közlöny egyetlen olyan szaklapunk, amelyért csereképpen biztosítani tudjuk hazai tudományunk részére a nélkülözhetetlenül szükséges szakirodalmat. Ezidőszerint 57 külföldi tudományos egyesülettel és intézménnyel állunk csereviszonyban és már többszáz könyvet, folyóiratot és monográfiát kaptunk csereképpen a Földtani Közlönyért. (...) Feltétlenül szükséges, hogy ezt a cserét, amely könyvállományunk külföldi irodalommal történő gyarapításának ezidőszerint egyetlen járható útja, magunk intézzük." Nem mulaszthatta el persze felhívni a figyelmet arra, hogy „mivel folyóiratunk csereként külföldre is kimegy, legnagyobb súlyt kell helyeznünk az éberség kérdésére. Szerzőinknek továbbra is gondosan kell ügyelniük arra, hogy közléseik semmiféle bizalmas adatot ne tartalmazzanak és minden tekintetben megfeleljenek népi demokráciánk követelményeinek" [80: 223]. A csere lebonyolítása valószínúleg ezidőtájt került az ELTE VADÁsz Elemér vezette Földtani Tanszékének hatáskörébe. Ez VADÁsz felelős szerkesztői megbízatásának vége (1967) után is így maradt, a tanszék a rendszerváltozás elôtti időszakban 160 példányt kapott a Közlönybőll, mígnem a postai díjak emelkedése, a tanszéki költségvetés csökkenése és a tanszéki könyvtárosoknak a leépítések miatti eltúnése a cserekapcsolatok 120 éves hagyományának is véget vetett.

\section{Különlenyomatok}

Bár már a 3. évfolyam egyik cikkéból ismeretes — talán a szerző költségén készült — különlenyomat, bizonyosan az 1875. II. 24-i választmányi ülés határozta el, hogy a „főbb cikkek szerzői” 25 különlenyomatot kapnak [5: 58]. A választmány 1911. V. 4-i ülésén úgy döntött, hogy különlenyomat csak a szerző kérésére nyomtatható, és ennek árával (egy ívig $10 \mathrm{~K}$, felette $20 \mathrm{~K}$ ) a szerzői díjat csökkentik, de ennek fejében minden különlenyomat borítólappal készül [40: 382]. 1916-ban a borítólapot megszüntették [46: 130]. A Társulaton belül múködő Barlangkutató Bizottság (majd szakosztály) közleményeit a Társulat ingyen nyomtatta, és belőlük 100 magyar és 50 német különlenyomatot is engedélyezett [41: 446]. Az 1916. IV. 5-i szabályzat ismét 50 ingyen különlenyomatot engedélyezett az eredeti értekezések számára borítólappal, a többinek anélkül. 1920. VI. 2-án a választmány úgy döntött, hogy „,míg a nagy drágaság és anyaghiány tart, a Közlöny munkatársainak csak 25 példány különlenyomatot bocsát ingyen rendelkezésére és azokat is boríték nélkül" [50: 76]. Az 1920-as évek közepén ennek is csak a felét fizette a Társulat [55: B2], de 1927-ben már újfent azt jelenthették be, hogy ,a helyzet lassú javulásával a t. szerzőknek 25 péld. különlenyomatot már ingyen adhatunk" [57: 87]. Nyomtatott információk hiányában a késôbbiekre nézve csak annyi biztos, hogy — talán a „legszúkebb esztendőket” kivéve — a szerzők mindig kaptak különlenyomatokat. Ezek előállítását nagyban megkönnyítette, hogy minden egyes cikk 1949 [79] óta új oldalon, 1982 [112] óta pedig új lapon kezdődik. A különlenyomatokat a 32.től a 72.-ig, majd a 82.-től a 119. évfolyamig borítóval is ellátták. A digitális kópiák (pdf) térnyerése miatt 2017 óta különlenyomatok még külön költségért sem igényelhetők. Eltörlésük előtt az utolsó időszakban cikkenként 25 db készült. 


\section{Szerzói tiszteletdíjak}

A mai olvasónak talán meglepó, de a tudományos lapok sokáig szerzői honoráriumot is fizettek. E gyakorlat a Közlöny esetében — többnyire a Társulat anyagi helyzetének függvényében rendkívül ingadozó volt. A választmány először 1874. XII. 27-én határozott a honoráriumok eltörléséről, már 1874-re visszamenőlegesen is [4: 312]. Késốbb visszaállították a tiszteletdíjakat, melyek összességükben tekintélyes összegre rúgtak (például 1878ban a Közlöny nyomdaköltsége 873 frt 10 kr, az írói díj 369 frt 65 kr volt [9: 56]). Ezért a kétnyelvú kiadás bevezetésekor ismét megszüntették a honoráriumfizetést [9: 36]. 1883-ban újólag bevezették, ,az eredeti értekezések és a kivonatos ismertetések vagy tanulmányok nyomtatott ívenként 25 frtjával, a fordítások s más efféle közlemények 20 frtjával" díjaztattak [13: 69]. 1887-ben az államsegély rendszeresítésekor 25-ról 30 Ft-ra emelték az ívenkénti tiszteletdíjat [17: 234]. Később is ezek az összegek voltak érvényben (az 1 frt = $2 \mathrm{~K}$ egyenérték alapján átszorozva), de az angol, francia vagy olasz fordítást 40 helyett $50 \mathrm{~K}$-val fizették [1. pl. 41: 375]. 1904-ben némi korlátozást vezettek be, mert egy évfolyamban ugyanazon szerzőnek egy tárgyról írott munkájáért csak két nyomtatott ív után járt tiszteletdíj, sôt ha a munka terjedelme ezt meghaladta, a két íven felüli rész nyomtatási költségét levonták a tiszteletdíjból [34: 250]. 1915. III. 3-án a háborús takarékossági kényszerre tekintettel a választmány felfüggesztette e szerzői díjak kiutalását, csak a fordítói díjakat fizette [45: 270-271], de az államsegély megérkezte után 1916. I. 1-i hatállyal visszaállították a honoráriumot [47: 279], a fordítói díjat pedig 1918. XI. 6-án 60 Kra emelték [48: 400]. A késốbbi időszakra vonatkozóan a Közlöny nem tartalmazott adatokat, de 1949 és 1990 között bizonyosan voltak olyan időszakok, amikor a Közlöny fizetett honoráriumot. A korszak végén már csak jelképesnek számító összeget utoljára a 120. évfolyam szerzői kapták meg.

\section{Repertóriumok (mutató és regiszterkötetek)}

Az R1-től R4-ig jelölt repertóriumok adatait l. a szakasz végén.

A Földtani Közlöny tartalmában történő, több szempont szerinti tájékozódást segítő mutatókból eddig négy kötet jelent meg, de ezek mindegyike csak egy idôszakra terjeszkedett ki — változó szerkezetben. Megjelenésük — érthetô módon — mindig a Társulat (és így a Közlöny) anyagi gondoktól mentes, konszolidált időszakaihoz kötődött. Először az 1881. I. 16-i választmányi ülésen vetôdött fel az, hogy tíz év után ,a rendkívül fontos register készítése már szóba kerülhet" [FÉ.2: 40]. Az 1881. III.2-i választmányi ülésen STÜRZENBAUM Józsefet bízták meg azzal, hogy az 1881-ig megjelent összes kiadványra „,a legalkalmasabb mód szerint három fócsoportra — név, tárgy és hely — osztott pontos registert készítene" [FÉ.2: 91-92] Az eredetileg a 11. évfolyamba szánt mutatót STÜRZENBAUM hirtelen halála miatt HALAVÁTS Gyula készítette el [23: 62, FÉ.3: 52], és végül az 1852-1882 periódust ölelte föl, РЕTHŐ Gyula első titkár előszava szerint azért, mert „1883-mal a Földtani Közlönynek mintegy új folyama indúlt meg" [R1: III]. Az 1 frt-ért árult kiadványból [R1] 600 példányt adtak ki, melyből az MKFI 100at kapott [14: 572], a társulati tagoknak 1885 elején küldték ki tagilletményként [16: 57]. Benne az előszó után az MFT kiadványainak felsorolása következik, majd a Társulati ügyek (tematikus bontásban), a Névmutató (mely valójában a közlemények szerzői ábécé szerinti címjegyzéke), Helymutató (pontosabban helynévmutató), Őslénytani mutató, végül Tárgymutató (ásvány- és kôzetnevek, földtani terminusok és egyéb címszavak). A mutatók a címszavak után végig a megfelelő kötet- és oldalszámot adják meg.
A következő repertórium [R2] elkészítésének ötlete 1901-ben merült fel, amikor a vezetôség ráébredt, hogy 1900-ban elfelejtette megünnepelni a Társulat fennállásának 50 éves jubileumát. A javaslatot KRENNER József tette a jubileum esetleges utólagos megünneplésének ügyében tartott 1901. V. 8-i választmányi ülésen [31: 168]. A munkával CHOLNOKY Jenőt bízták meg. Az előzőhöz amúgy meglehetôsen hasonló jellegú kötet szerkezete annyiban eltér elődjéétől, hogy kimaradt belőle a társulati ügyek mutatója, és a korábbi tárgymutató kettéoszlott. Ennek megfelelően az öt rész a következő: I. A közlemények szerzôi ábécé szerinti címjegyzéke. II. Földrajzi mutató (valójában helynévmutató), III. Tárgymutató, IV. Ásvány- és kőzetnévmutató, V. Paleontológiai mutató. A címszavakhoz itt is kötet- és oldalszámok tartoznak. E kiadvány elkészülése is késlekedett (1. [32: 69], [33: 77]), végül 1903 első felében jelent meg.

1926-ban a Társulat elnöke felvetette, hogy ,nagy hiányt pótolna a Földtani Közlöny mutatójának elkészítése is, mert 1900 óta, tehát 26 éve, nem jelent meg, ami felette megnehezíti az irodalom felkeresését. Egyelőre nincsen rá fedezetünk, de e kérdést is állandóan felszínen tartjuk, s amint lehetséges, megjelentetjük" [57: 87]. Végül erre 1961-ig kellett várni, ekkor jelent meg az 19011960 közti [31-90] évfolyamokra kiterjedő regiszterkötet [R3]. A BoDA Jenô, KASZAP András és LENGYEL Endre által összeállított kötetet VÉGH Sándorné szerkesztette. Mintájául a MÁFI 1955-ben megjelentett, saját kiadványaihoz készített betûrendes mutatót vették. Az 1961-es regiszterkötetben a korábbi mutatókhoz képest a legfontosabb különbség, hogy a szerzői ábécé szerinti (sorszámozott) címjegyzék (I. rész) után tárgynevek és szakszavak helyett — nyilván a hatalmas, 60 évfolyamnyi anyag miatt — szakmai témakörök szerinti mutató következik (II. rész), mely nem kötet- és oldalszámokra, hanem a címjegyzék sorszámaira utal vissza. Hasonlóképpen, helynévmutató helyett a szakmai mutató „,regionális földtan” szakcsoportja (a 4. oldal térképvázlatán feltüntetett) földtani tájak szerinti beosztás szerint csoportosítva sorolja föl az adott területre vonatkozó közlemények sorszámát. A III. rész (Társulati élet és egyebek) is tematikus bontásban tartalmazza a közleményeket, de itt már a kötet- és oldalszámokkal, hiszen az ide sorolt tartalmak a cím szerinti listába általában nem illettek bele. Ide tartozik az „Irodalom”, „Hírek”, „Hivatalos közlemények a Földtani Intézetből”, „Hírek, vegyesek”, illetve név szerinti ábécérendben a személyeket érintő cikkek, a „Jubileumi ünneplések”, a „Nekrológok; Emlékbeszédek, megemlékezések”, valamint a Szabó József-emlékéremmel kapcsolatos közlemények. A mutató 250 példányban jelent meg.

1977-ben az elnökség és a választmány elhatározta a Közlöny új regiszterkötetének kiadását [107: 254]. A negyedik — és máig utolsó -, DoBos Irma és Molnár József által összeállított, MeISEL Jánosné által szerkesztett kötet [R4] az 1961-1975-ös időszakot [91-115] öleli fel, és bizonyos mértékig ötvözi az előző regiszterek megoldásait. A sorszámozott címjegyzék után egy háromrészes „Szakmai mutató” következik Tárgymutató, Földrajzi mutató és Szerzői névmutató beosztással, ezek — [R1]-hez és [R2]-höz hasonlóan - címszavakat tartalmaznak, viszont a címszavak után kötet- és oldalszámok helyett — [R3]-mal egyezően - a vonatkozó cikkek címjegyzékbeli sorszámai találhatók. A következő fejezetek viszont, amelyek a címjegyzékbe általában be nem sorolható közleményekre vonatkoznak, természetesen e mutató is már a közlemény kötet- és oldalszámát adja meg. Az „Irodalom” fejezet a magyar földtani irodalom évenként közölt jegyzékének e bibliográfiai adatait tartalmazta, majd a „Személyi ügyek” fejezetben a különböző fokozatú tudományos minősítések, a jubileumi köszöntések, illetve a nekrológok és 
megemlékezések bibliográfiai adatai következtek az érintett személy neve szerint, időrendben. A „Társulati élet” fejezet csak a közgyúlési anyagok adatait tartalmazza, majd a „Hírek” fejezet a személyi hírek bibliográfiai adatait, szintén az érintett személy neve és évszám szerint, majd az egyéb hírekét, azok jellegének megadása nélkül, időrendi sorrendben.

$$
* * *
$$

[R1] A magyarhoni Földtani Társulat 1852-1882. évi összes kiadványainak betüsoros tartalom-mutatója. Összeállitotta HALAVÁTs Gyula. / General-Index sämmtlicher Publicationen der Ung. Geolog. Gesellschaft von den Jahren 1852-1882. Franklin-Társulat Könyvnyomdája, Budapest, 1884
[R2] Mutató a Földtani Közlöny XIII-XXX. köteteihez. Összeállította CHOLNOKY Jenő dr. / General-Register zu den Bänden XIII-XXX. des Földtani Közlöny (Geologische Mitteilungen). Zusammengestellt von Dr. E. von Cholnoky. FranklinTársulat Nyomdája, Budapest, 1903.

[R3] Földtani Közlöny. Regiszter kötet 1900 [recte: 1901] 1960. Összeállították: BoDA Jenő, KASZAP András, LENGYEL Endre. Szerkesztette: VÉGH Sándorné. Magyar Földtani Társulat, Budapest, Akadémiai Nyomda, 1961.

[R4] Földtani Közlöny. Regiszter kötet 1961-1975. Összeállította: Dr. Dobos Irma, Molnár József. Szerkesztette: Meisel Jánosné. Magyarhoni Földtani Társulat, Budapest, Alföldi Nyomda, 1981. 